\title{
VARIAÇÃO GENÉTICA PARA QUALIDADE NUTRICIONAL EM MILHO COM ENDOSPERMA NORMAL
}

\author{
ANDRÉA MITTELMANN
}

Engenheiro Agrônomo

Orientador: Prof. Dr. JOSÉ BRANCO DE MIRANDA FILHO

Tese apresentada à Escola Superior de Agricultura "Luiz de Queiroz", Universidade de São Paulo, para obtenção do título de Doutor em Agronomia, Área de Concentração: Genética e Melhoramento de Plantas.

PIRACICABA

Estado de São Paulo - Brasil

Outubro -2001 


\section{ERRATA}

\section{MITTELMANN, A. Variação genética para qualidade nutricional em milho com endosperma normal}

p. ítem

ix resumo

xi summary

192.6

192.6

$30 \quad 3.3 .1$

37 Tabela 3

$53 \quad 4.2 .3$

64 Tabela 4

65 Tabela 5

705

705 linha onde se lê

24 composição de aminoácidos

20 aminoacid composition

4 Allison e Curnow (1996)

8 Charcosset et al., 1990b

110,51

6 58,99 (quadrado médio do efeito de populações para o caráter LEU)

8 tem-se $\mathrm{F}=0$ nas famílias $\mathrm{S}_{1}$

1 Análise de variância agrupada por local

1 Análise de variância agrupada por testador

9 Composição de aminoácidos

10 as associação leia-se

composição da proteína em termos de aminoácidos aminoacid composition of the protein

Allison e Curnow (1966)

Charcosset et al., 1990

10,81

$58,99 * *$

tem-se $\mathrm{F}=0$, referente às plantas $S_{0}$ que deram origem às famílias $S_{1}$ Análise de variância conjunta para testadores, por local Análise de variância conjunta para locais, por testador Composição da proteína em termos de aminoácidos as associações 
Dados Internacionais de Catalogação na Publicação (CIP)

DIVISÃO DE BIBLIOTECA E DOCUMENTAÇÃO - ESALQ/USP

Mittelmann, Andréa

Variaçăo genética para qualidade nutricional em milho com endosperma normal /

Andréa Mittelmann. - Piracicaba, 2001.

$93 \mathrm{p}$.

Tese (doutorado) - Escola Superior de Agricultura Luiz de Queiroz, 2001.

Bibliografía.

1. Aminoácido 2. Divergência genética 3. Melhoramento genético vegetal 4. Milho 5. Óleo 6. Proteína 7. Valor nutritivo I. Título

CDD 633.15

"Permitida a cópia total ou parcial deste documento, desde que citada a fonte - $\mathrm{O}$ autor" 
"O homem que venceu na vida
é aquele que viveu bem,
riu muitas vezes e amou muito."

\author{
Ao Fábio, \\ meu eterno amor \\ DEDICO
}




\section{AGRADECIMENTOS}

Ao concluir, com a apresentação deste trabalho, o curso de Doutorado, desejo expressar meus agradecimentos:

Ao Prof. José Branco de Miranda Filho, pela orientação neste trabalho e pelo tratamento sensível e humano;

Aos demais professores do Departamento de Genética da ESALQ/USP pelos ensinamentos;

À excelente equipe de funcionários do Departamento de Genética da ESALQ/USP pela convivência e pelo auxílio prestado durante o curso, especialmente àqueles diretamente envolvidos na condução e avaliação dos experimentos;

Ao Dr. Gustavo José Mello M. de Lima e equipe do Laboratório de Análises Físico-Químicas da EMBRAPA Suínos e Aves pela amizade e o empenho na realização do grande número de análises químicas necessárias a este trabalho;

Ao acadêmico de Engenharia Agronômica da ESALQ/USP Ricardo Takao Tanaka pela responsabilidade e dedicação com que auxiliou na condução e avaliação dos experimentos;

Ao Dr. Luciano Lourenço Nass, pela amizade e sugestões ao trabalho;

A todos os colegas de curso, especialmente Ângela Célis de Almeida Lopes, Alessandra Pereira Fávero, Andréa Guelfi, Aurélio Mendes Aguiar, Américo José dos Santos Reis, Caroline Moor Wagner, Cláudio Yuji Tsutsumi, Eduardo Leonardecz Neto, Fernando Enrique Ninamango Cárdenas, Juliano Gomes Pádua, Maurisrael de Moura Rocha, Raimundo Nonato Vieira da Cunha, Ricardo Machado da Silva, Sandro Ricardo 
Fuzzato, Vanderlei da Silva Santos e Vanoli Fronza, que colaboraram nas diferentes fases da realização deste trabalho;

À Coordenação de Aperfeiçoamento de Pessoal de Nível Superior (CAPES) pela concessão da bolsa de estudos;

A minha família, por ser sempre unida e sempre o meu porto seguro;

À família Zanelatto-Pandini, minha segunda família, por ter me recebido com amor e me ensinado muito;

Às amigas Ângela C. A. Lopes, Alessandra P. Fávero, Lourdes e Aparecida Peterman, Renata e Fernanda Pereira da Cruz, Cristine L. Handel e Ana Lídia Variani Bonato, pontos de apoio nos momentos mais difíceis. 


\section{SUMÁRIO}

Página

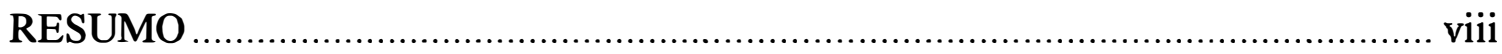



1 INTRODUÇÃO











2.2.3 Seleção para qualidade em endosperma normal ............................................ 9







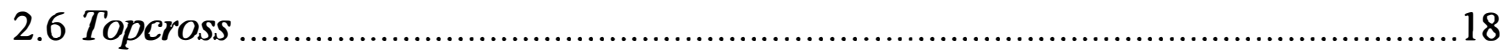

3 QUALIDADE NUTRICIONAL EM POPULAÇÕES BRASILEIRAS DE



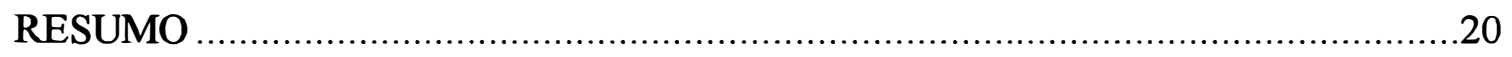











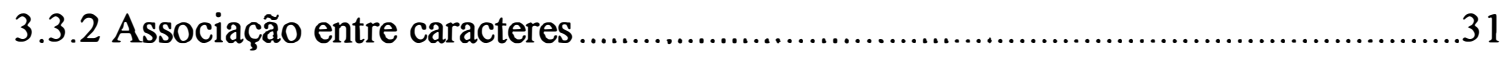








4 AVALIAÇÃO DO POTENCIAL DA POPULAÇÃO ESA23B PARA O MELHORAMENTO DE PROTEÍNA E ÓLEO ATRAVÉS DE









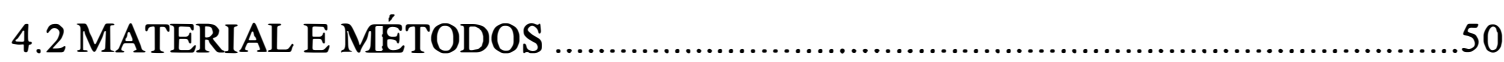











4.3.2 Variância aditiva interpopulacional e ganho genético ………...........................56














\title{
VARIAÇÃO GENÉTICA PARA QUALIDADE NUTRICIONAL EM MILHO COM ENDOSPERMA NORMAL
}

\author{
Autora: ANDRÉA MITTELMANN \\ Orientador: Prof. Dr. JOSÉ BRANCO DE MIRANDA FILHO
}

\section{RESUMO}

O objetivo deste trabalho foi identificar a variação existente para caracteres relacionados à qualidade nutricional entre e dentro de populações de milho com endosperma normal. Para isto, dois experimentos foram realizados. No primeiro experimento, dez populações foram avaliadas em três ambientes: Estação Experimental do Anhembi na época normal de cultivo e na safrinha e Estação Experimental da Caterpillar na safrinha. Os experimentos foram conduzidos em delineamento de blocos casualizados com seis repetições. Foram avaliados o rendimento de espigas, percentuais de proteína, óleo e fibra bruta nos grãos, assim como dos aminoácidos lisina (LIS), metionina (MET), treonina (TRE), serina (SER), ácido glutâmico (GLU), prolina (PRO), glicina (GLI), alanina (ALA), valina (VAL), isoleucina (ILE), leucina (LEU), tirosina (TIR), fenilalanina (FEN), histidina (HIS), arginina (ARG), cistina (CIS), ácido aspártico (ASP). O segundo experimento consistiu na avaliação dos híbridos resultantes do cruzamento de 120 famílias $S_{1}$ da população ESA23B com dois testadores, sendo uma variedade de polinização aberta (BR108) e uma linhagem exótica (CML269). Os ensaios foram realizados em dois locais: Estação Experimental do Anhembi e Estação Experimental da Caterpillar (Piracicaba, SP). O delineamento utilizado foi em blocos 
casualizados com três repetições. Foram avaliados os caracteres peso de espigas, peso de grãos, teor de proteína e teor de óleo. No primeiro experimento houve diferença entre as populações para a maioria dos caracteres estudados, com pouca expressão da interação populações $\mathrm{x}$ ambientes. Houve associação positiva entre o percentual de proteína e a maioria dos aminoácidos, considerados com base na matéria seca. Quando considerados com base na proteína total, alguns dos aminoácidos foram negativamente correlacionados com o percentual de proteína. As dez populações foram divididas em quatro grupos com base na distância euclidiana média. No segundo experimento foi detectada diferença entre as progênies para todos os caracteres. As médias dos testcrosses variaram de $8,40 \%$ a $11,82 \%$ para teor de proteína e de $3,77 \%$ a 5,10\% para teor de óleo. Híbridos com média semelhante ou superior à da melhor testemunha foram identificados para teor de proteína, peso de espigas e peso de grãos. As estimativas da variância aditiva interpopulacional, foram de 0,553 a 1,124 para o teor de proteína e de 0,034 a 0,057 para teor de óleo (dados em percentual). Em um dos experimentos, a estimativa de variância aditiva não foi significativamente diferente de zero para peso de espigas e para peso de grãos, variando nos demais experimentos de 362,83 a 521,74 para o primeiro caráter e de 212,40 a 381,73 para o segundo (dados em gramas por planta). Com base nos resultados, foi possível concluir que: a) tanto as dez populações estudadas quanto as progênies dentro da população ESA23B divergem para a maioria dos caracteres, indicando a possibilidade de seleção de genótipos com melhor qualidade nutricional; b) a interação tratamentos $\mathrm{x}$ ambientes teve pouca influência no experimento envolvendo populações, permitindo a seleção para a média dos ambientes, mas foi importante no experimento de topcross, o que indica que a melhor forma de seleção deve ser analisada caso a caso; c) a composição de aminoácidos varia de acordo com o teor de proteína; d) as associação entre qualidade nutricional e rendimento foram fracas e, em geral, não significativas; portanto, não deve haver dificuldade na obtenção de cultivares de milho que reunam ambos os caracteres. 


\title{
GENETIC VARIATION FOR NUTRICIONAL QUALITY IN MAIZE WITH NORMAL ENDOSPERM
}

\author{
Author: ANDRÉA MITTELMANN \\ Adviser: Prof. Dr. JOSÉ BRANCO DE MIRANDA FILHO
}

\section{SUMMARY}

The objective of this work was to identify variation among and within populations with normal endosperm for nutritional quality related traits. Two experiments were conducted. In the first experiment, ten populations were evaluated in three environments: Experimental Station of Anhembi under normal season and offseason planting and Experimental Station of Caterpillar at Piracicaba under off-season planting. Experiments were conducted under the completely randomized block design with six replications. The following traits were evaluated: ear yield, protein, oil, and crude fiber, as well as the content of aminoacids lysine (LIS), methionine (MET), treonine (TRE), serine (SER), glutamic acid (GLU), proline (PRO), glycine (GLI), alanine (ALA), valine (VAL), isoleucine (ILE), leucine (LEU), tyrosine (TIR), fenilalanine (FEN), hystidine (HIS), arginine (ARG), cystine (CIS), aspartic acid (ASP). The second experiment was a topcross in witch $120 \mathrm{~S}_{1}$ families from ESA23B population were crossed with two testers, an open-pollinated population (BR108) and an exotic line (CML269). Testcrosses were evaluated at two locations: Experimental station of Anhembi and Experimental Station of Caterpillar (Piracicaba, SP), under the completely randomized block design with three replications. Ear yield, grain yield, 
protein content and oil content were evaluated. In the first experiment, significant differences among populations were detected for most of the traits, with little expression of population $\mathrm{x}$ environment interaction. Positive association between protein content and most of the aminoacids in dry-matter basis has occurred. When considered in percent of total protein, some of the amino acids were negatively correlated with protein content. The ten populations were clustered in four groups, based on Euclidean mean distance. In the second experiment, differences among progenies were detected for all the traits. Testcross means varied from $8.40 \%$ to $11.82 \%$ for protein content and from $3.77 \%$ to $5.10 \%$ for oil content. Hybrids with means similar or superior to the best check were identified for protein content, ear yield, and grain yield. Estimates of the interpopulacional additive variance were from 0.553 to 1.124 for protein content and from 0.034 to 0.057 for oil content (percent data). In one of the experiments, additive variance estimates were not significantly different from zero for ear yield and grain yield, but in the others it varied from 362.83 to 521.74 and from 212.40 to 381.73 respectively (data in grams per plant). Based on the results the conclusions were: a) populations and progenies within population ESA23B differed for most of the traits, showing possibility for selection of superior genotypes for nutritional quality; b) treatment $x$ environment interaction had little influence in the first experiment, allowing selection based on the means, but was important in the second, suggesting that the ideal way of selection must be studied case by case; c) aminoacid composition varies with protein content; d) associations between nutritional quality and yield were weak and, generally, not significant; therefore, simultaneous selection for both traits will not be difficult. 


\section{INTRODUÇÃO}

Os grãos de milho possuem inúmeras utilizações, tanto na forma natural como na industrializada. Em muitos países em desenvolvimento, representam parte importante na dieta humana, de forma que não podem ser considerados apenas como uma fonte de energia pois também contribuem com uma porção importante das proteínas.

Outra utilização de grande importância dos grãos de milho é na alimentação animal, especialmente de aves e suínos. No Brasil são produzidas anualmente mais de 30 milhões de toneladas de ração, representando uma demanda de cerca de 20 milhões de toneladas de milho (Anfar, 2001). As aves e suínos apresentam exigências quanto ao teor de proteína e de aminoácidos essenciais na dieta, sendo que a suplementação destes pode representar custos adicionais, uma vez que a alimentação representa a maior parte dos custos de produção. Do mesmo modo, tem sido demonstrado que suínos e aves alimentados com milho contendo alta concentração de óleo apresentam maior ganho de peso, maior produção de ovos e menor consumo de alimento.

Assim, o desenvolvimento de variedades de milho com maiores teores de proteína e óleo e um balanço adequado de aminoácidos, permitindo a elevação do valor nutritivo sem prejuízo acentuado do rendimento de grãos, representa um grande desafio a ser alcançado pelo melhoramento genético.

Os esforços para a obtenção de genótipos de milho de qualidade nutricional superior vinham sendo limitados pelo alto custo das análises convencionais de nutrientes e a falta de conhecimento sobre as bases genéticas e bioquímicas do acúmulo destes. $\mathbf{O}$ avanço dos conhecimentos nas áreas da genética, bioquímica e biologia molecular e a disponibilidade de novos equipamentos e metodologias de análise permitem, atualmente, 
a realização de estudos mais detalhados sobre a composição química dos grãos. Estes estudos abrem caminho para a adoção de novas estratégias no melhoramento para qualidade nutricional do milho, até então dependente, em grande parte, da utilização de genes mutantes.

O primeiro passo para o estabelecimento de um programa de seleção baseado em herança quantitativa é a quantificação da variabilidade existente. Assim sendo, o objetivo deste trabalho foi identificar a variação genética existente entre e dentro de populações de milho para caracteres relacionados à qualidade nutricional dos grãos, 


\section{REVISÃO DE LITERATURA}

O grão de milho é composto de três partes principais: pericarpo, endosperma e embrião. $O$ endosperma representa cerca de $83 \%$ do peso do grão, o embrião, em média, $11 \%$ e o pericarpo, $5 \%$. Assim, mesmo contendo aproximadamente $87 \%$ de amido e $8 \%$ de proteína, o endosperma aporta a maior parte das proteínas do grão, as quais em geral variam de oito a onze por cento (FAO, 1993). Assim, a composição de aminoácidos do grão inteiro reflete a composição das proteínas do endosperma, embora as proteínas do embrião possuam um melhor balanço de aminoácidos.

O valor nutritivo ou qualidade de proteína do milho expresso em unidades de caseína é semelhante ao dos demais cereais, em geral deficientes para alguns aminoácidos essenciais, com exceção do arroz (FAO, 1993). O milho apresenta deficiências em lisina, triptofano e treonina, demonstradas em estudos com animais e humanos (Zarkadas et al., 1995). Foi igualmente detectada uma deficiência em isoleucina, atribuída aos elevados teores de leucina, que prejudicam sua absorção (Benton et al., 1955, 1956; Zarkadas et al., 1995).

As proteínas do grão podem ser classificadas de acordo com sua solubilidade em diferentes solventes, estando formadas por cinco frações distintas. As albuminas, globulinas e o nitrogênio não protéico representam cerca de $18 \%$ do nitrogênio total. A fração prolamina, que no milho recebe a denominação de zeína, constitui aproximadamente $52 \%$ do nitrogênio dos grãos e as glutelinas $25 \%$ (Landry \& Moreaux). As zeínas, que representam uma grande porção das proteínas do endosperma, possuem níveis extremamente baixos de lisina e não possuem triptofano, explicando a deficiência destes aminoácidos nos grãos de milho (Nelson, 1969). Devido a estas 
características, muitos esforços têm sido feitos visando melhorar o valor nutritivo dos grãos de milho, em grande parte através da manipulação genética.

Por outro lado, é comum na formulação de rações o milho ser misturado ao farelo de soja. Este é capaz de compensar as deficiências em lisina e triptofano mas, por sua vez, é extremamente deficiente em metionina. Nesta situação, a seleção para teores mais elevados de metionina no milho se torna desejável, a fim de evitar a necessidade de adição de metionina sintética (Paulis et al., 1978). Porém, poucos trabalhos têm sido desenvolvidos no sentido do melhoramento para o teor de metionina em milho.

Com relação ao teor de óleo, em geral os grãos de milho apresentam de 3,5 a $5 \%$, o qual está localizado principalmente no embrião, que é responsável por 83 a $85 \%$ do total de óleo nos grãos (Alexander, 1986). O óleo de milho é considerado de melhor qualidade em relação ao de soja, pois é composto de $85 \%$ de ácidos graxos não saturados, apresentando melhor digestibilidade e menor risco de causar problemas cardiovasculares (Beadle et al., 1965; Fitch, 1985). A utilização de milho com alto teor de óleo em rações permite maior ganho de peso por quantidade de alimento ingerida, o que tem sido demonstrado tanto para suínos (Nordstron et al., 1972) quanto para aves (Hann et al., 1987). Isto ocorre porque o óleo apresenta maior valor calórico que o amido. Portanto, embora não seja um nutriente considerado deficiente, há interesse no aumento do teor de óleo nos grãos. Em vários países existem variedades com alto teor de óleo, as quais são recomendadas para uso em rações.

\subsection{Melhoramento para teor de proteína}

O teor de proteína é um caráter quantitativo e diversos estudos têm apontado para um grande número de genes envolvidos em seu controle. Tanto efeitos aditivos como não aditivos são importantes no controle do caráter (Sreeramulu \& Bauman, 1970). Dudley \& Lambert (1992) estimaram em 173 o número de genes afetando este caráter. Em um estudo de QTL envolvendo 80 marcadores regularmente espaçados no genoma, 16 marcadores agrupados em oito regiões estiveram associados ao teor de

proteína. Destes, três locos mostraram apenas efeitos aditivos, dez apresentaram 
aditividade e dominância e três apenas efeito de dominância (Berke \& Rocheford, 1995). A dominância ocorre essencialmente no sentido da redução do caráter (East \& Jones, 1920; Berke \& Rocheford, 1995).

Efeitos de ambiente e da interação genótipo $\mathrm{x}$ ambiente significativos são em geral detectados para o teor de proteína (Genter et al., 1956; Berke \& Rocheford, 1995). Entre os fatores de ambiente que influenciam o teor de proteína destacam-se a temperatura e a disponibilidade de água e nitrogênio no solo (East \& Jones, 1920; Oikeh, 1998). Em uma mesma espiga, o tamanho dos grãos e sua posição também influenciam o teor de proteína (East \& Jones, 1920).

Do ponto de vista da variação genética, o genótipo da planta em que a espiga se desenvolve é o principal determinante do teor de proteína, sendo que o genótipo do pólen não afeta significativamente a proteína nos grãos (East \& Jones, 1920; Letchworth \& Lambert, 1998).

Híbridos brasileiros de milho, comparados em um ensaio realizado em Chapecó, SC, na safra 1999/2000, apresentaram teor de proteína variando de 8,3 a 13,7\% na matéria seca. A média dos 56 genótipos avaliados foi de 10,9\% (Lima et al., 2000a). Entretanto, a média histórica das amostras de origens diversas analisadas pela EMBRAPA/Centro Nacional de Pesquisa de Suínos e Aves é de 8,7\% (EMBRAPA, 1991).

Analisando famílias $F_{3}$ derivadas do cruzamento entre as linhagens IHP (Illinois High Protein) e ILP (Illinois Low Protein) resultantes de 76 gerações de seleção massal divergente para teor de proteína, foram detectados 22 locos de marcadores de RFLP (restriction fragment lenght polimorfism) associados ao teor de proteína, distribuídos em onze braços cromossômicos (Goldman, et al., 1993). Entretanto, no mesmo estudo, um modelo de regressão múltipla considerando seis locos provenientes de diferentes cromossomos explicou mais de $64 \%$ da variação total para o teor de proteína.

A existência de variabilidade e a possibilidade de seleção para o conteúdo de proteína em milho têm sido demonstradas em diversos estudos. Zimback (1985) analisou progênies de duas subpopulações da população Composto braquítico VD opaco e obteve 
estimativas de variância aditiva de 0,57 e 0,55 e herdabilidade de $59 \%$ e $56 \%$ para as subpopulações A e B, respectivamente.

Em um experimento clássico, iniciado por Hopkins em 1896, a população Burr's White foi selecionada em direções opostas, para alto (IHP) e baixo (ILP) teor de proteína. Após setenta e seis gerações de seleção massal a variabilidade genética para teor de proteína ainda não havia sido exaurida, embora a média da última geração (IHP) superasse em 139\% ou 20 desvios padrão a da população original (Dudley, 1977). Após 90 gerações de seleção foi realizado o cultivo, no mesmo experimento, de populações

representando os últimos 25 ciclos. $\mathrm{O}$ ganho médio por ciclo de seleção foi de $0,13 \pm$ 0,02 pontos percentuais. A freqüência de alelos favoráveis para alto teor de proteína na população inicial foi estimada em 0,32 . Na população selecionada para redução do teor de proteína foi observado que o progresso genético havia cessado depois de atingido um valor de aproximadamente 4\% de proteína nos grãos (Dudley \& Lambert, 1992).

Em outro trabalho, a análise de um grande número de populações revelou amostras com alto teor de proteína (12-15\%), muitas delas entre populações locais da Moldávia. Após 12 anos de seleção recorrente, progênies com até 23-24\% de proteína foram obtidas, sem que a variabilidade genética fosse esgotada. Através de cruzamentos entre as quatro famílias com maior teor de proteína foi observado que este caráter era reduzido consideravelmente na $F_{1}$; entretanto, as melhores famílias das gerações $F_{2}$ a $F_{5}$ superavam os parentais na maioria dos cruzamentos. De acordo com os autores, isto significa que os alelos favoráveis para o caráter estão dispersos entre as populações. Existe, portanto, a possibilidade de concentração destes em um único genótipo (Micu et al., 1995).

\subsection{Melhoramento para qualidade de proteína}

O melhor aproveitamento biológico dos grãos de milho reside não apenas no conteúdo de proteína mas, principalmente, na seleção de genótipos com composição de aminoácidos balanceada. 
O melhoramento para qualidade de proteína em milho tem sido, em grande parte, baseado no uso de genes mutantes, os quais freqüentemente possuem efeitos pleiotrópicos indesejáveis. As limitações desta estratégia, associadas à existência de variabilidade para os teores de aminoácidos essenciais e a novas técnicas mais rápidas e eficientes de análise sugerem a utilização de uma abordagem quantitativa na seleção, com a utilização de seleção recorrente.

\subsubsection{Mutantes para qualidade de proteina}

Vários mutantes que modificam favoravelmente as características da proteína do endosperma do milho, elevando os níveis de lisina e triptofano, já foram identificados. Em 1964 foi demonstrado que o gene mutante opaco-2 $\left(o_{2}\right)$, utilizado inicialmente como um marcador genético devido às alterações que causa no fenótipo do grão, era capaz de alterar o padrão da síntese protéica, promovendo um aumento significativo no conteúdo de lisina (Mertz et al., 1964). O mutante amiláceo floury-2 $\left(f l_{2}\right)$ também foi identificado como possuindo efeitos favoráveis à qualidade de proteína (Nelson et al., 1965). Ourros mutantes conhecidos que provocam um aumento nos teores de lisina e triptofano podem ser citados, entre eles o opaco-6 $\left(o_{6}\right)$, opaco-7 $\left(o_{7}\right)$, floury-3 $\left(f l_{3}\right)$, mucronado $(M c)$, endosperma defectivo $(D e-B 30)$, opaco-11 $\left(o_{11}\right)$ e opaco 7749 , sendo que este último se destaca por possuir alto teor de lisina sem grande redução das zeínas (Vasal, 1994). A presença do gene mutante sugary- $I\left(s u_{l}\right)$ provocou um aumento no teor de metionina de 21 e $31 \%$, respectivamente, nas linhagens de milho B37 e Oh43, acompanhado de significativo aumento no teor de lisina. Porém, houve uma acentuada redução do peso de 100 grãos (Paulis et al., 1978).

Maior esforço foi despendido na utilização do mutante $o_{2}$, pois sua herança é simples e não é influenciada por nenhum efeito de dosagem para o aspecto do grão ou para a qualidade de proteína (Vasal, 1994). O mutante $o_{2}$ está localizado no cromossomo 7 (posição 16) e é recessivo, manifestando seus efeitos apenas quando em condição homozigota. $\mathrm{O}$ loco $\mathrm{O}_{2}$ codifica um ativador transcripcional que regula a expressão dos genes de $\alpha$-zeínas (Kodrzycki et al., 1989). Assim, a maior concentração de lisina nos 
mutantes $o_{2}$ é uma conseqüência da redução na acumulação de zeínas, proteínas pobres neste aminoácido, e no aumento da fração não-zeína.

Entretanto, após os primeiros estudos envolvendo a transferência deste alelo para materiais de endosperma normal foi observada a ocorrência de uma série de efeitos indesejáveis. A presença do mutante $o_{2}$ torna o endosperma macio e amiláceo, o que facilita a seleção fenotípica, mas provoca redução do peso específico dos grãos, maior ocorrência de quebra, maior teor de umidade na colheita e maior suscetibilidade a insetos. Além disto, os genótipos mutantes foram, em geral, menos produtivos que seus correspondentes normais (Lambert et al., 1969; Sreeramulu \& Bauman, 1970). Estes efeitos impediram a expansão da utilização de cultivares com alta qualidade de proteína, exigindo a adoção de novas estratégias para o melhoramento desta característica.

\subsubsection{Genes modificadores}

O enfoque inicial no uso de genes modificadores foi a alteração do fenótipo dos grãos. Entretanto, com o progresso dos estudos foi observado que todo o complexo de problemas relacionados ao mutante $o_{2}$ poderia ser revertido com o emprego destes genes modificadores (Vasal,1994).

A descoberta de grãos sabidamente homozigotos para o alelo $o_{2}$ contendo parte do endosperma vítreo gerou a hipótese da existência de um complexo de genes modificadores atuando sobre o gene $o_{2}$ (Paez et al., 1969). Este fato trouxe um novo impulso à pesquisa e utilização deste gene no melhoramento, através do desenvolvimento de variedades denominadas Quality Protein Maize ou QPM. No Brasil, a EMBRAPA/ Centro Nacional de Melhoramento de Milho e Sorgo iniciou o trabalho com genótipos QPM em 1984, tendo lançado as variedades BR451 e BR473 e o híbrido BR2121 (Pacheco et al., 1999).

O estudo de linhagens QPM desenvolvidas na África do Sul evidenciou ser a ação gênica aditiva a responsável, em grande parte, pela modificação dos grãos. Além disso, a capacidade geral de combinação para endosperma vítreo e densidade do 
endosperma foi positivamente correlacionada com o acúmulo de genes modificadores parcialmente dominantes (Hohls et al., 1996). Através de marcadores moleculares de RFLP, Lopes et al. (1995) mapearam dois locos que contribuem para a variação no fenótipo dos grãos, um próximo ao telômero e outro próximo ao centrômero do braço longo do cromossomo 7. Os dois locos foram mapeados em populações diferentes.

Os mecanismos moleculares através dos quais atuam os genes modificadores ainda não são conhecidos. Entretanto, a comparação entre cultivares normais, opacas e modificadas mostrou que os materiais QPM contém duas a quatro vezes mais gamazeínas que os demais. Como o mutante $o_{2}$ não afeta a expressão desta classe de proteínas, isto indica que a ação dos genes modificadores é independente do loco $o_{2}$ (Wallace et al., 1990).

Entretanto, tem sido apontado que a introdução dos genes modificadores causa uma redução no teor de lisina, em relação aos genótipos contendo apenas o gene $o_{2}$ (Gentinetta et al., 1975). Alguns autores apontam ainda a necessidade de melhoramento adicional dos genótipos QPM pois, em geral, o conteúdo de lisina em percentual da proteína encontrado está abaixo do mínimo recomendado pela FAO (Moro et al., 1996).

\subsubsection{Seleção para qualidade em endosperma normal}

Um enfoque alternativo ao uso de genes mutantes é a exploração da variação existente para os teores de aminoácidos em populações de milho normal, através de seleção recorrente. Esta estratégia permite que a qualidade da proteína seja manipulada geneticamente sem que as características fisicas do grão sejam alteradas. Além disso, é possível obter valores ainda mais altos de teor de lisina em genótipos QPM, através da exploração da variação quantitativa, pois os dois sistemas complementam-se de maneira aditiva (Choe et al., 1976).

O aminoácido mais abundante nos grãos de milho é o ácido glutâmico (aproximadamente $21 \%$ da proteína total), que junto com leucina, prolina, alanina, fenilalanina, valina e ácido aspártico responde por 67 a $69 \%$ do total de aminoácidos, enquanto lisina, triptofano e metionina são os aminoácidos presentes em menor 
quantidade (Nelson et al., 1965; Zarkadas et al., 1995). O teor mínimo de lisina recomendado para dietas humanas é de $5 \mathrm{mg} / 100 \mathrm{mg}$ de proteína (FAO/WHO, 1985; FAO/WHO, 1990).

Significativa variabilidade para o teor de lisina foi observada tanto entre linhagens normais como entre linhagens homozigotas para o mutante $o_{2}$. As primeiras apresentaram 0,13 a $0,28 \%$ de lisina na matéria seca e 1,6 a 2,6\% na proteína total e as últimas variaram de 0,24 a $0,48 \%$ de lisina na matéria seca e de 2,8 a 4,5\% na proteína total (Moro et al., 1996). As linhagens $\mathrm{O}_{2}$ apresentaram, em média, 40\% mais lisina que suas respectivas versões normais; porém, no total de genótipos avaliados algumas linhagens normais foram superiores a outras contendo o alelo mutante.

Em um estudo abrangendo 182 variedades, representando praticamente todas as raças de milho conhecidas, Tello et al. (1965) concluíram que o teor de lisina é influenciado pela raça da qual se originou a cultivar. As raças Tepecintle, White NalTel, Salvadoreño Complex (TWNTS), Chepo, Flint Cubano, Shandelle e Pira obtiveram destaque por apresentar o maior percentual de variedades com alto teor de lisina. Por outro lado, a raça Tuxpeño produziu somente cultivares com baixo teor de lisina.

A avaliação de um conjunto de dez variedades normais de milho mostrou diferença significativa para os teores de lisina e triptofano em relação ao nitrogênio total entre os quatro locais de ensaio utilizados. A interação locais $x$ variedades foi significativa, sendo que a diferença entre variedades ocorreu em todas as análises individuais por local mas não na análise conjunta (Bressani, et al., 1962). Os autores sugeriram que o melhoramento para teor de lisina deveria ser feito a nível local, já que os quatro locais empregados pertenciam a diferentes países da América Latina.

Através de seleção recorrente, Zuber (1975) obteve um aumento gradual do teor de lisina na matéria seca, em duas das três populações estudadas. Além disto, ao cruzar famílias selecionadas para teores contrastantes de lisina (alto e baixo) com um testador homozigoto para $\mathrm{o}$ mutante $o 2$, a diferença na qualidade foi transferida às progênies. Isto sugere que ao menos dois sistemas genéticos diferentes estão envolvidos na síntese de lisina, podendo a seleção em termos quantitativos melhorar a qualidade de proteína mesmo daqueles genótipos que já contém o mutante $o_{2}$ (Choe, 1976). 
Em um dialelo entre oito linhagens contendo o gene $o_{2}$, o efeito da capacidade geral de combinação para teor de lisina na matéria seca foi significativo; porém, o efeito da capacidade específica de combinação não foi significativo, indicando a predominância de efeitos aditivos para o caráter (Sreeramulu \& Bauman, 1970).

Em um experimento realizado no Brasil com 56 híbridos comerciais, não foram observadas diferenças expressivas quanto aos teores de lisina na matéria seca, os quais ficaram entre 0,25 e $0,27 \%$. Por outro lado, o teor de treonina variou de 0,24 a $0,36 \%$ e o de metionina variou de 0,29 a $0,32 \%$ (Lima et al., 2000a). Também foram relatadas diferenças significativas entre populações para os teores dos aminoácidos metionina, leucina, isoleucina e valina em percentual da proteína (Bressani et al., 1962). Garcia (1993) procurou melhorar a qualidade nutricional através da seleção para o percentual de triptofano na matéria seca. Após quatro ciclos de seleção recorrente fenotípica, houve progresso apenas em uma das duas populações estudadas, sendo este de $0,7 \%$ por ciclo. O ganho indireto para teor de triptofano em percentual da proteína foi de $1,26 \%$ por ciclo.

A taxa leucina/isoleucina influencia no aproveitamento biológico desta última, sendo desejáveis valores mais baixos. O valor obtido para um genótipo QPM foi de 2,50, comparado a valores entre 3,62 e 3,70 obtidos para genótipos sem o gene mutante o2 (Zarkadas et al., 1995). Entre híbridos comerciais brasileiros os teores de leucina na matéria seca variaram de 0,65 a $1,54 \%$ e os de isoleucina de 0,33 a $0,53 \%$ (Lima et al., 2000a).

A seleção para a composição das proteínas de milho foi limitada durante muito tempo pela necessidade de análises precisas e laboratórios bem equipados (Vasal, 1994). A análise de aminoácidos representa alto custo, especialmente considerando o grande número de amostras que são avaliadas regularmente em um programa de melhoramento. Atualmente, técnicas mais rápidas e eficientes podem auxiliar nestes estudos. 


\subsection{Melhoramento para teor de óleo}

De acordo com Dudley (1977), o teor de óleo nos grãos de milho é uma característica quantitativa, sendo controlado por um grande número de genes. A variância genética aditiva parece ser o principal componente no controle deste caráter. Berke \& Rocheford (1995) detectaram 31 locos de RFLP associados ao teor de óleo em famílias $S_{1}$ derivadas do cruzamento entre plantas de duas populações selecionadas de maneira divergente para teor de óleo por 90 gerações, os quais estavam agrupados em onze regiões do genoma. Destes, 22 locos apresentaram apenas efeitos aditivos, oito apresentaram efeitos aditivos e de dominância e um apenas efeito de dominância. Os principais QTL para teor de óleo foram localizados nos cromossomos 2, 5, 6 e 9. Sete locos de RFLP, localizados nos cromossomos $2,3,5,6,8$ e 9 , responderam por $61 \%$ da variação genotípica total para teor de óleo, mesmo se tratando de um cruzamento entre genótipos extremamente divergentes para o caráter (Berke \& Rocheford, 1995).

O teor de óleo parece ser menos influenciado pelos efeitos de ambiente e da interação genótipo x ambiente que o teor de proteína (Genter et al., 1956; Berke \& Rocheford, 1995). Entretanto, foi observado que os grãos da base e do ápice da espiga apresentam menor teor de óleo que os da porção central. Esta variação é devida a efeito de ambiente e deve ser levada em conta a fim de evitar sua influência na seleção (Lambert et al., 1967).

Entre 56 híbridos brasileiros de milho avaliados em Chapecó, SC, na safra 1999/2000 os teores de óleo variaram de 3,6 a 6,9\% na matéria seca (Lima et al., 2000a).

Packer (1998) analisou famílias $S_{1}$ e de irmãos germanos provenientes de cinco populações de milho, no município de Piracicaba, SP. A população EMGOPA-19 C1 destacou-se, com média de 7,6\% de óleo para as famílias $S_{1}$ e 7,5\% para as de irmãos germanos, contra 5,6\% do híbrido comercial utilizado como testemunha.

Silva (1990) condensou os resultados de diversos autores em relação a estimativas de parâmetros genéticos para o teor de óleo, expresso em percentagem, incluindo vários trabalhos realizados no Brasil. Foram identificadas estimativas de variância aditiva, para teor de óleo em percentual, entre 0,08 e 1,55. Nos trabalhos que 
estimaram variância de dominância, a proporção desta em relação à variância aditiva foi de 0,13 a 0,23 . As estimativas de herdabilidade no sentido restrito e ao nível de planta variaram de 9,8 a $85,8 \%$. A média dos resultados colhidos na literatura por Hallauer \& Miranda Filho (1981) para a variância genética aditiva, dados em percentual, foi de 0,82; para a variância de dominância 0,09 e para a herdabilidade $76,7 \%$.

Diversos trabalhos têm comprovado a eficiência da seleção recorrente para o aumento do teor de óleo. Em um experimento conduzido na Universidade de Illinois, com 90 ciclos de seleção, a população denominada IHO (Illinois High Oil) passou de 4,7 a $19,3 \%$ de óleo, representando um ganho de aproximadamente 22 vezes o desvio padrão aditivo da população original. $\mathrm{O}$ ganho médio por ciclo de seleção para os últimos 25 ciclos, avaliados em um mesmo experimento, foi de $0,14 \pm 0,02$ pontos percentuais. A freqüência de alelos favoráveis na população inicial foi estimada em 0,22. A população selecionada no sentido contrário, denominada ILO (Illinois Low Oil) chegou a menos de $1 \%$ de óleo nos grãos, tendo cessado o progresso genético em função da baixa viabilidade dos grãos e da dificuldade de realização das análises de óleo. $\mathrm{O}$ número de genes contribuindo para a divergência entre IHO e ILO em relação ao teor de óleo foi estimado em 69 (Dudley \& Lambert, 1992). Onze ciclos de seleção de grãos individuais na população Zhongzong $\mathrm{n}^{\circ} .2$ permitiram chegar a uma população contendo $11,25 \%$ de óleo, o que corresponde a 2,39 vezes a média ou 8,6 vezes o desvio padrão da população original (Song et al., 1999). Vinte e quatro ciclos de seleção na população Alexho Synthetic permitiram um aumento no teor de óleo de 5,1 para $17,0 \%$, ou seja, 0,49 pontos percentuais por ciclo (Misevic \& Alexander, 1989). Em nenhum dos trabalhos citados houve sinal de esgotamento da variabilidade genética para o caráter.

O controle maternal, ou seja, a influência do genótipo da planta mãe, é apontado como o efeito predominante na determinação do conteúdo de óleo nos grãos (Miller \& Brimhall, 1951; Garwood et al., 1970; Batista \& Tosello, 1982). Este engloba as contribuições fisiológicas e citoplasmáticas da planta mãe, sendo difícil separar experimentalmente estes dois componentes. Porém, também ocorre influência do genótipo paterno (Miller \& Brimhall, 1951; Alexander \& Lambert, 1968; Letchworth \& Lambert, 1998). 
O processo de fertilização dupla, característico dos vegetais superiores, introduz o material genético do pólen no tecido do endosperma, assim como no embrião. A influência hereditária dos genes do pólen no endosperma é denominada xênia. Em 1997, foi patenteado um sistema denominado "Topcross" para a produção comercial de grãos de milho com alto teor de óleo, tirando proveito do efeito de xênia. $O$ processo consiste em semear um polinizador com alto teor de óleo junto com um genótipo macho-estéril com teor de óleo normal e com alto potencial de rendimento. As sementes do polinizador são misturadas em uma proporção de 7 a $8 \%$ do total. Nos experimentos realizados, o teor de óleo nos grãos foi aumentado em $72 \%$ em relação ao pólen normal, sem efeitos sobre o rendimento de grãos (Lambert et al., 1998; Alexander, 1999). Este sistema não deve ser confundido com o delineamento genético de mesmo nome, que envolve a utilização de testadores em cruzamento com os genótipos a serem avaliados.

\subsection{Associações entre caracteres}

As associações entre teor de proteína e teor de óleo têm variado de não significativas (Dorsey-Redding et al.,1991; Séne et al., 2001) a valores positivos elevados (Song et al., 1999).

Vários autores detectaram correlações negativas entre o conteúdo de proteína e o rendimento de grãos, indicando que quando plantas de alto rendimento são selecionadas, o conteúdo de proteína é reduzido, o que poderia explicar o generalizado baixo percentual de proteína entre os híbridos comerciais (Corcuera \& Naranjo, 1995).

Os autores sugerem a seleção simultânea para ambos os caracteres como uma alternativa vantajosa para a solução do problema. Recentemente, alguns autores têm sugerido que as correlações fenotípicas negativas entre teor de proteína e produtividade freqüentemente encontradas em cereais não são causadas por efeitos genéticos, e sim, de ambiente (Kibite \& Evans, 1984). A correlação genética aditiva entre teor de proteína e produtividade estimada para a população Composto braquítico VD opaco não foi significativa (Zimback, 1985). 
Do mesmo modo, alguns trabalhos apontam a existência de correlações negativas entre teor de óleo e rendimento de grãos (Misevic \& Alexander, 1989; Tatis, 1990). Porém, Alexander \& Lambert (1968) concluíram que a capacidade da planta produzir carboidratos e a de sintetizar óleo são fisiologicamente independentes no intervalo de 4 a 7\% de óleo. Em duas populações brasileiras de milho, Piranão VD-2 e Piranão VF-1, foram estimadas correlações genéticas aditivas positivas entre estes caracteres, com valores de 0,44 e 0,47, respectivamente (Silva, 1990).

Dudley \& Lambert (1992) observaram que a cada aumento de um ponto percentual no teor de proteína, correspondia uma redução de 1,6 gramas no peso de cem grãos, o que contribuiria para a redução da produtividade total. Correlação negativa entre teor de óleo e peso de cem grãos foi detectada na população Composto braquítico VD opaco, mas não do primeiro com a produtividade (Zimback, 1985). Correlações negativas e de valores elevados têm sido detectadas entre teor de proteína e teor de amido e entre teor de óleo e teor de amido (Dudley \& Lambert,1992; Berke \& Rocheford, 1995; Lambert et al., 1997; Song et al., 1999), o que poderia levar a uma redução no tamanho e rendimento de grãos. Entretanto, outros autores têm obtido correlações não significativas dos teores de óleo e proteína com o tamanho (peso) dos grãos (Batista, 1980; Berke \& Rocheford, 1995; Song et al., 1999). Lambert et al. (1996) sugerem o uso de índices de seleção considerando as concentrações de proteína, óleo, amido e o tamanho de grãos para obtenção de genótipos agronomicamente superiores.

Um argumento levantado em defesa do conceito de que altos rendimentos e maiores concentrações de óleo e proteína não são caracteres mutuamente exclusivos é que, ao longo do tempo, tem havido significativos ganhos no rendimento de grãos dos híbridos comerciais, devido ao melhoramento genético, enquanto a concentração de nutrientes não tem sido afetada (Lambert et al., 1998; Vyn \& Tollenaar, 1998).

A seleção para alto teor de óleo tem sido em geral acompanhada de aumento no tamanho do embrião, ou da proporção deste em relação ao grão, e de maior concentração de óleo no embrião, indicando uma associação com estes caracteres (Miller \& Brimhall, 1951; Lambert et al., 1997). Batista (1980) realizou cinco ciclos de seleção entre 
famílias de meios-irmãos para produtividade e dentro destas para tamanho do embrião, obtendo uma resposta correlacionada de 1,44\% por ciclo para o teor de óleo.

As zeínas, proteínas pobres em lisina e triptofano, são a principal fração aumentada com a seleção para alto teor de proteína (Frey, 1951; Alexander et al., 1969). Tem sido observado que o aumento no teor de lisina causado pelo mutante $o_{2}$ é devido principalmente à redução da fração protéica correspondente à zeína. Em um experimento com 93 genótipos, o teor de proteína foi, em geral, mais baixo nos genótipos contendo o alelo $o_{2}$ que em seus correspondentes de endosperma normal (Moro et al.,1996). Alguns trabalhos com genótipos de endosperma normal têm encontrado correlações negativas entre o teor de lisina e triptofano, em percentual da proteína, e a proteína total (Bressani et al., 1962; Tello et al., 1965). Por outro lado, existe correlação positiva entre teor de lisina e triptofano na matéria seca com a proteína total (Nelson, 1969; Zuber, 1975). Choe et al. (1976) observaram que o aumento do teor de lisina na matéria seca foi acompanhado de um aumento da proteína total, sem que nenhuma seleção fosse exercida sobre este caráter. Em um dialelo envolvendo genitores com o gene $o_{2}$, o teor de proteína não foi significativamente correlacionado com o teor de lisina em percentual da proteína, mas foi negativamente correlacionado com o teor de lisina em percentual da matéria seca (Sreeramulu \& Bauman, 1970).

Quanto aos demais aminoácidos, existe pouca informação na literatura. Em populações segregantes oriundas de dois cruzamentos foram detectadas correlações significativas entre os aminoácidos isoleucina, leucina, valina e triptofano na matéria seca, sendo que as associações entre os três primeiros foram mais fortes que aquelas envolvendo o triptofano (Frey, 1951). Bressani et al. (1962) detectaram, para um conjunto de dez variedades avaliadas em quatro ambientes, correlações negativas com a proteína total para os aminoácidos isoleucina e valina em percentual da proteína, mas não para leucina e metionina. Além disso, os teores de lisina e leucina em percentual da proteína foram positivamente correlacionados entre si. 


\subsection{Distância genética e análise de agrupamento}

A diversidade genética entre populações tem sido avaliada com o objetivo de predição de cruzamentos com maior efeito heterótico ou com maior probabilidade de gerar segregantes superiores. A análise de agrupamento tem por finalidade reunir os genótipos de forma que haja homogeneidade dentro e heterogeneidade entre grupos. $\mathrm{O}$ agrupamento é realizado com base nas medidas de distância genética.

As medidas de dissimilaridade mais utilizadas para dados quantitativos são a distância euclidiana média (d) e a distância generalizada de Mahalanobis $\left(D^{2}\right)$. Ambas têm a capacidade de contornar os problemas relativos ao número e à escala de avaliação dos caracteres; porém, $\mathrm{D}^{2}$ leva em consideração as correlações entre os caracteres avaliados podendo ser estimada quando os dados provêm de ensaios com repetições (Cruz \& Regazzi, 1994).

Diversos trabalhos têm estimado distâncias genéticas a partir de caracteres agronômicos em milho. Em geral, do ponto de vista da heterose, uma divergência moderada entre os pais leva a melhores resultados que uma divergência muito alta (Prasad \& Singh, 1985). Da mesma forma, existe a necessidade de que os genes envolvidos no controle dos caracteres utilizados no cálculo das distâncias estejam em desequilíbrio de ligação com os genes envolvidos na heterose (Charcosset et al., 1991). Resultados de simulações indicam que a associação entre distância genética e heterose diminui com o aumento no número de locos que controlam os caracteres morfológicos utilizados na estimativa das distâncias (Burstin \& Charcosset, 1996). Além disso, para que a média do híbrido para um determinado caráter seja alta é necessário que os genitores não sejam apenas divergentes, mas que possuam uma média elevada para 0 caráter de interesse (Prasad \& Singh, 1985). Alguns autores têm observado relação entre as distâncias genéticas e aspectos relacionados à região de origem dos acessos, como fatores climáticos, tipo de alimento à base de milho elaborado pela população, troca de germoplasma com regiões vizinhas.

A análise de agrupamento também tem sido utilizada com o objetivo de identificar subconjuntos de acessos com potencial para usos específicos. No caso da 
composição química do milho, o estabelecimento de uma classificação permitiria uma melhor utilização na elaboração de rações e a redução de custos. Da mesma forma, poderia permitir a remuneração diferenciada aos produtores de milho.

As técnicas de análise multivariada possuem grande utilidade para diferenciar e agrupar genótipos, considerando o grande número de características envolvidas no conceito de qualidade nutricional. Lima et al. (2000b) classificaram 57 amostras de milho quanto a qualidade nutricional em quatro grupos, a partir das distâncias euclidianas. Os caracteres avaliados foram teor de proteína, óleo, fibras e lisina na matéria seca, sendo que maior diferenciação foi encontrada em relação aos dois primeiros. Em outro estudo, 66 amostras foram reunidas em três grupos, com base nos percentuais de proteína, óleo, fibra, cinza e dezessete aminoácidos (Barioni et al., 2000).

\subsection{Topeross}

No esquema de cruzamentos denominado topcross todos os genótipos a serem testados são cruzados com um mesmo testador e seu valor genético é determinado com base em contrastes de médias. Este sistema foi proposto por Davis (1927) e Jenkins \& Brunson (1932) e é hoje amplamente utilizado tanto para o desenvolvimento de novas combinações híbridas como em esquemas de seleção recorrente (Miranda Filho \& Gorgulho, 2001). Sua principal vantagem em relação ao dialelo é reduzir o número de híbridos a serem avaliados.

Em programas de seleção recorrente para posterior extração de linhagens, a seleção com base em testcrosses é superior à seleção entre famílias intrapopulacionais quando existe dominância para o caráter (Holthaus \& Lamkey, 1995). Neste delineamento, a expressão "capacidade de combinação" é empregada no sentido generalizado, independentemente de ser o testador de base genética ampla ou estreita (Miranda Filho \& Gorgulho, 2001).

Um dos aspectos a serem considerados na utilização do esquema topcross é a escolha do testador. Hallauer (1975) afirmou que um testador deve possuir simplicidade no uso, gerar informação que classifique corretamente o valor dos genótipos testados e 
maximizar o ganho genético. Teoricamente, o melhor testador seria homozigoto recessivo para todos os locos, pois isto maximizaria a variância entre os testcrosses, evitando que a presença de alelos dominantes pudesse "mascarar" o verdadeiro valor dos genótipos testados. Allison \& Curnow (1996) enfatizaram que o melhor testador seria uma linhagem homozigota recessiva ou uma população com baixa freqüência alélica para os locos mais importantes. Realmente, diversos autores obtiveram maior sucesso na seleção com o uso de linhagens endogâmicas e de baixo valor per se para os caracteres de interesse (Horner et al., 1973; Charcosset et al., 1990b).

Por outro lado, há casos em que a escolha do testador ocorre por outros critérios, como quando já existe uma linhagem elite ou um híbrido com características adequadas para utilização como fêmea nos cruzamentos, ou quando se dispõe de um par heterótico conhecido para a população que está sendo testada (Miranda Filho \& Gorgulho, 2001). Castellanos et al. (1998) consideraram a variância entre testcrosses, a capacidade geral de combinação do testador, a correlação com outros testadores e a performance per se como critérios na seleção de testadores para um programa de desenvolvimento de híbridos.

Quando se utiliza um testador não relacionado, é possível estimar a variância genética interpopulacional, e o ganho genético pode ser estimado somente em relação ao híbrido, uma vez que a população de referência não é a população base, e sim o conjunto dos testcrosses (Miranda Filho \& Vencovsky, 2001). 


\section{QUALIDADE NUTRICIONAL EM POPULAÇÕES BRASILEIRAS DE MILHO}

\section{RESUMO}

$\mathrm{O}$ desenvolvimento de variedades de milho com maiores teores de proteína $\mathrm{e}$ óleo e um balanço adequado de aminoácidos, sem prejuízo do rendimento de grãos, representa um desafio a ser alcançado pelo melhoramento genético. $\mathrm{O}$ objetivo deste trabalho foi estudar a qualidade nutricional dos grãos em dez populações de milho, verificando a variabilidade entre populações, a importância relativa dos efeitos de ambiente e da interação de populações com ambientes sobre os caracteres nutricionais e as associações destes caracteres entre si e com a produtividade. As dez populações foram avaliadas em três ambientes: Estação Experimental do Anhembi na época normal de cultivo e na safrinha e Estação Experimental da Caterpillar na safrinha. Os experimentos foram realizados em delineamento de blocos casualizados com seis repetições. Foram avaliados o rendimento de espigas, percentuais de proteína, óleo e fibra bruta nos grãos, assim como dos aminoácidos lisina (LIS), metionina (MET), treonina (TRE), serina (SER), ácido glutâmico (GLU), prolina (PRO), glicina (GLI), alanina (ALA), valina (VAL), isoleucina (ILE), leucina (LEU), tirosina (TIR), fenilalanina (FEN), histidina (HIS), arginina (ARG), cistina (CIS), ácido aspártico (ASP). Análises de variância por experimento e conjunta foram realizadas, sendo calculados os componentes quadráticos associados aos efeitos de ambientes, populações e interação populações $x$ ambientes. Foram feitas comparações de médias e calculadas as correlações de Spearman entre os caracteres. Houve diferença entre as populações para a 
maioria dos caracteres estudados, com pouca expressão da interação populações $\mathrm{x}$ ambientes. A composição de aminoácidos variou de acordo com o teor de proteína, havendo associação positiva entre o percentual de proteína e a maioria dos aminoácidos, considerados com base na matéria seca. Quando considerados com base na proteína total, alguns dos aminoácidos foram negativamente correlacionados com o percentual de proteína. As dez populações foram divididas em quatro grupos com base na distância euclidiana média.

\section{NUTRITIONAL QUALITY IN BRAZILIAN MAIZE POPULATIONS}

\section{SUMMARY}

The development of corn cultivars with high protein and oil content and an appropriate aminoacid composition, without losts in grain yield, represents a challenge to be reached by genetic breeding. The objective of this work was to study grain nutritional quality in ten maize populations, verifying the variability among populations, the relative importance of effects of environment and the populations by environments interaction on nutritional traits, and the associations of these characters to each other and with yield. The ten populations were evaluated in three environments: Experimental Station of Anhembi under normal season and off-season planting and Experimental Station of Caterpillar at Piracicaba under off-season planting. Experiments were conducted in the completely randomized block design with six replications. The following traits were evaluated: ear yield, protein, oil, and crude fiber, as well as the content of aminoacids lysine (LIS), methionine (MET), treonine (TRE), serine (SER), glutamic acid (GLU), proline (PRO), glycine (GLI), alanine (ALA), valine (VAL), isoleucine (ILE), leucine (LEU), tyrosine (TIR), fenilalanine (FEN), hystidine (HIS), arginine (ARG), cystine (CIS), aspartic acid (ASP).Individual and combined analysis of variance were performed and the quadratic components for the effects of environments, populations, and their interaction were calculated. Population means were compared and 
Spearman correlations among traits were calculated. Significant differences among populations were detected for most of the traits, with little expression of population $\mathrm{x}$ environment interaction. Aminoacid composition varied with protein content. Positive association between protein content and most of the aminoacids in dry-matter basis has occured. When considered in percent of total protein, some of the amino acids were negatively correlated with protein content. The ten populations were clustered in four groups, based on Euclidean mean distance. 


\subsection{INTRODUÇÃO}

Os grãos de milho possuem inúmeras utilizações, tanto na forma natural como na industrializada. Em muitos países em desenvolvimento, representam parte importante na dieta humana, de forma que não podem ser considerados apenas como uma fonte de energia pois também contribuem com uma porção importante das proteínas. (FAO, 1993). Também são de grande importância na alimentação animal, especialmente de aves e suínos, que apresentam exigências quanto ao teor de proteína e de aminoácidos essenciais na dieta, sendo que a suplementação destes pode representar custos adicionais à criação.

O melhor aproveitamento biológico dos grãos de milho reside não apenas no conteúdo de proteína mas, principalmente, na composição balanceada de aminoácidos. $\mathrm{O}$ valor nutritivo ou qualidade de proteína do milho, expresso em unidades de caseína, é semelhante ao dos demais cereais, em geral deficientes para alguns aminoácidos essenciais (FAO, 1993). O milho apresenta deficiências em lisina, triptofano e treonina, demonstradas em estudos com animais e humanos (Zarkadas et al., 1995). Foi igualmente detectada uma deficiência em isoleucina, atribuída aos elevados teores de leucina, que prejudicam sua absorção (Benton et al. citados por Zarkadas et al., 1995). Por outro lado, é comum na formulação de rações o milho ser misturado ao farelo de soja. Este é capaz de compensar as deficiências em lisina e triptofano mas, por sua vez, é extremamente deficiente em metionina. Nesta situação, a seleção para teores mais elevados de metionina no milho se torna desejável, a fim de evitar a necessidade de adição de metionina sintética (Paulis et al., 1978). Porém, poucos trabalhos têm sido desenvolvidos no sentido do melhoramento para o teor de metionina.

O óleo de milho é considerado de melhor qualidade em relação ao de soja, pois é composto de $85 \%$ de ácidos graxos não saturados, apresentando melhor digestibilidade e menor risco de causar problemas cardiovasculares (Beadle et al., 1965; Fitch, 1985). Além disso, o óleo apresenta maior valor calórico que o amido. Portanto, embora não seja um nutriente considerado deficiente, há interesse no aumento do teor de óleo nos grãos. A utilização de milho com alto teor de óleo permite maior ganho de peso por 
quantidade de alimento ingerido, tanto para suínos (Nordstron et al., 1972) quanto para aves (Hann et al., 1987). Os grãos de milho apresentam geralmente de 3,5 a 5\% de óleo (Alexander, 1986). Em vários países existem variedades com alto teor de óleo recomendadas para uso em rações, as quais possuem teor de óleo acima de $6 \%$.

Os teores de proteína e óleo são caracteres quantitativos e diversos trabalhos têm demonstrado a existência de variabilidade e a possibilidade de obter sucesso com seleção recorrente (Dudley, 1977; Misevic \& Alexander, 1989; Dudley \& Lambert, 1992; Song et al., 1999). Por outro lado, o melhoramento para qualidade de proteína em milho tem sido em grande parte baseado no uso de genes mutantes, que freqüentemente possuem efeitos pleiotrópicos indesejáveis. As limitações desta estratégia, associadas à existência de variabilidade para os teores de aminoácidos essenciais e a novas técnicas mais rápidas e eficientes de análise, sugerem a utilização de uma abordagem quantitativa na seleção.

Tem sido observada expressiva variabilidade para o teor de lisina, tanto entre linhagens normais como entre linhagens homozigotas para o gene mutante opaco-2 $\left(\mathrm{O}_{2}\right)$. As primeiras apresentaram 0,13 a 0,28\% de lisina na matéria seca e 1,6 a 2,6\% na proteína total e as últimas variaram de 0,24 a $0,48 \%$ de lisina na matéria seca e de 2,8 a 4,5\% na proteína total (Moro et al., 1996). Segundo esses autores, mesmo os genótipos QPM (Quality Protein Maize) devem ser selecionados para maior teor de lisina pois, em geral, este encontra-se abaixo do mínimo recomendado para dietas humanas, que é de 5 mg/100 mg de proteína (FAO/WHO/UNV, 1985; FAO/WHO, 1990).

Em um experimento realizado no Brasil com 56 híbridos comerciais, não foram observadas diferenças expressivas quanto aos teores de lisina na matéria seca, os quais ficaram entre 0,25 e $0,27 \%$. Por outro lado, o teor de treonina variou de 0,24 a $0,36 \%$ e o de metionina variou de 0,29 a 0,32\% (Lima et al., 2000a). Também foram relatadas diferenças significativas entre populações para os teores dos aminoácidos metionina, leucina, isoleucina e valina em percentual da proteína (Bressani et al., 1962).

A taxa leucina/isoleucina influencia no aproveitamento biológico desta última, sendo desejáveis valores baixos. O valor obtido para um genótipo QPM foi de 2,50 comparado a valores entre 3,62 e 3,70 obtidos para genótipos sem o gene $o_{2}$ (Zarkadas et 
al., 1995). Entre híbridos comerciais brasileiros, os teores de leucina na matéria seca variaram de 0,65 a 1,54\% e os de isoleucina de 0,33 a 0,53\% (Lima et al., 2000a).

$\mathrm{Na}$ caracterização de populações quanto aos seus atributos mais importantes, as técnicas de análise multivariada podem ser importantes, porque levam em consideração diversos caracteres, simultaneamente. Alguns trabalhos aplicando estas técnicas ao estudo da qualidade nutricional têm sido desenvolvidos (Lima et al., 2000b; Barioni et al., 2000).

Os objetivos deste trabalho foram: a) verificar a existência de variabilidade entre as populações estudadas em relação à qualidade nutricional dos grãos, e agrupá-las de acordo com esta variação; b) verificar a importância relativa dos efeitos de ambiente e da interação de populações com ambientes sobre os caracteres nutricionais; c) estudar as associações destes caracteres entre si e com a produtividade.

\subsection{MATERIAL E MÉTODOS}

Neste trabalho foram avaliadas seis populações desenvolvidas no Programa de Melhoramento de Milho da ESALQ/ USP, denominadas Composto GO Flint (F), Composto GO Dente (D), Composto GO Amarelo (A), Composto GO Branco (B), Composto GO Longo (L), Composto GO Grosso (G) e quatro sintéticos formados a partir de populações do Centro Nacional de Pesquisa de Milho e Sorgo (EMBRAPA/CNPMS) denominados GN-01, GN-02, GN-03 e GN-04. Como testemunha foi utilizado o híbrido triplo comercial G-85 (Novartis Seeds). As populações denominadas Compostos GO foram originadas de espigas selecionadas visualmente, em experimentos instalados na região de Rio Verde, Goiás, no ano agrícola de 1994/95, e têm apresentado alto potencial produtivo (Silva, 2001).

Os onze tratamentos foram instalados a campo em delineamento de blocos casualizados com seis repetições. Cada parcela foi composta por duas linhas com $4 \mathrm{~m}$ de comprimento, sendo o espaçamento entre linhas de $0,9 \mathrm{~m}$ e entre plantas de $0,2 \mathrm{~m}$. Os ensaios foram realizados em três ambientes: Estação Experimental do Anhembi na época 
normal de cultivo e na safrinha e Estação Experimental da Caterpillar na safrinha, sendo ambos no município de Piracicaba (SP).

$\mathrm{O}$ rendimento de espigas foi avaliado, sendo corrigido para o estande ideal de 40 plantas por parcela pelo método da covariância. Os valores resultantes foram transformados para toneladas por hectare. Após a colheita e debulha dos experimentos, uma amostra de grãos de cada parcela foi retirada, em três das seis repetições, para a análise da composição química.

Análises do percentual de proteína bruta, fibra bruta e óleo nos grãos foram realizadas, assim como dos percentuais de dezessete aminoácidos essenciais: lisina (LIS), metionina (MET), treonina (TRE), serina (SER), ácido glutâmico (GLU), prolina (PRO), glicina (GLI), alanina (ALA), valina (VAL), isoleucina (ILE), leucina (LEU), tirosina (TIR), fenilalanina (FEN), histidina (HIS), arginina (ARG), cistina (CIS), ácido aspártico (ASP). As análises foram realizadas no Laboratório de Análises FísicoQuímicas do Centro Nacional de Pesquisa de Suínos e Aves da Empresa Brasileira de Pesquisa Agropecuária (CNPSA/EMBRAPA), em Concórdia - SC.

As amostras foram moídas em um moinho de faca refrigerado Knifetec 1095 (Tecator) após os grãos terem sido quebrados em um moinho de disco Cemotec 1090 (Tecator). As análises foram feitas através da metodologia de NIR (near infrared reflectance spectroscopy), utilizando um instrumento NIRSystem 6500 com curvas de calibração desenvolvidas no próprio laboratório.

A metodologia empregada para obtenção das curvas de calibração utilizou os seguintes procedimentos, recomendados pela Association of Official Analytical Chemists (AOAC, 1995):

- matéria seca - secagem em estufa a $105^{\circ} \mathrm{C}$ de um dia para o outro;

- proteína bruta - método Kjeldahl;

- óleo - extração em éter utilizando aparelho Soxhlet;

- fibra bruta - digestão ácida $\left(\mathrm{H}_{2} \mathrm{SO}_{4}\right.$ a $\left.1,25 \%\right)$ seguida de digestão básica ( $\mathrm{NaOH}$ a $1,25 \%)$;

- aminoácidos - cromatografia líquida. 
Todos os valores foram ajustados para a matéria seca. Adicionalmente, foram obtidos os percentuais dos aminoácidos em relação à proteína bruta, através da expressão $\mathrm{AA}_{(\% \text { proteina })}=\left(\mathrm{AA}_{(\% \text { matéria seca })} / \mathrm{PB}\right) * 100$.

Análises de variância por ambiente e conjunta foram realizadas, incluindo as dez populações em estudo, para todos os caracteres, exceto LIS em percentual da matéria seca. Os efeitos de populações e ambientes, assim como da interação populações $\mathrm{x}$ ambientes foram considerados fixos. Os componentes quadráticos associados aos efeitos de ambientes, populações e interação populações $\mathrm{x}$ ambientes foram calculados com base nos quadrados médios esperados para o modelo da análise de variância. $\mathrm{O}$ caráter LIS em percentual da matéria seca não atendeu às pressuposições em relação à normalidade dos resíduos e homogeneidade das variâncias de tratamentos; portanto, não foi incluído nas análises de variância.

As médias das populações foram comparadas entre si pelo teste de Tukey e com a média da testemunha através do teste $t$, ambos a $5 \%$ de probabilidade. Foram obtidas as correlações de Spearman entre o peso de espigas, teor de proteína, teor de óleo, teor de fibras e os aminoácidos. As correlações envolvendo o caráter peso de espigas foram realizadas separadamente por ambiente.

A divergência entre as populações foi estimada pela distância euclidiana média (d) com dados padronizados, segundo a expressão a seguir, em que $\mathrm{d}_{\mathrm{ii}}$ é a distância euclidiana média entre os genótipos i e i', $p$ é o número de caracteres considerados e $\mathrm{x}_{\mathrm{ij}} \mathrm{e}$


desvio padrão.

$$
d_{i i^{\prime}}=\sqrt{\frac{\sum\left(x_{i j}-x_{i^{\prime j}}\right)^{2}}{p}}
$$

Foram considerados apenas os caracteres de maior importância para o melhoramento: teor de proteína, teor de óleo e os aminoácidos LIS, MET, TRE, ILE e LEU em percentual da proteína. A contribuição relativa dos caracteres para a divergência foi estimada conforme Singh (1981). Para os dois procedimentos, foi utilizado o programa Genes (Cruz, 1995). A análise de agrupamento foi realizada pelo 
método UPGMA (unweighted pair-group method with arithmetic average), utilizando o programa NTSYS (Rohlf, 1971). Depois de estabelecidos os grupos, foi realizada nova análise de variância para estes caracteres, a fim de verificar a significância dos efeitos de grupos e de tratamentos dentro de grupos, considerando ambos os efeitos fixos. As médias de grupos foram obtidas e comparadas pelo teste de Tukey a $5 \%$ de probabilidade.

\subsection{RESULTADOS E DISCUSSÃO}

Nas análises de variância conjuntas, os efeitos da interação entre populações e ambientes foram não-significativos para a grande maioria dos caracteres em estudo (Tabelas 1, 2 e 3). Apenas para os caracteres peso de espigas, percentual de fibra, PRO e TIR na matéria seca houve significância deste efeito, a $5 \%$ de probabilidade. Assim, as demais análises foram realizadas com base na análise conjunta, ou seja, para a média dos três ambientes. Bressani et al. (1962) observaram a presença de interação genótipoambiente significativa para teor de proteína e todos os aminoácidos estudados, que incluíam LIS, MET, VAL, LEU e ILE em percentual da proteína. Entretanto, os locais utilizados representavam quatro diferentes países latino-americanos, apresentando presumivelmente maiores diferenças edafo-climáticas que as representadas neste trabalho.

A variação entre populações foi significativo para a maioria dos caracteres, com exceção de ARG na matéria seca e ARG, TRE, ALA, VAL, TIR, FEN e HIS em percentual da proteína. Os seis últimos aminoácidos citados apresentaram diferenças entre populações quando analisados na matéria seca mas não quando analisados em percentual da proteína. Isso indica que sua variação no primeiro caso deve estar associada à variação na proteína total. Para ARG, o coeficiente de variação observado nas análises de variância foi bastante alto (próximo de $20 \%$ ), quando comparado aos dos demais aminoácidos, o que indica uma menor precisão experimental, dificultando a deteç̧ão de diferenças significativas entre populações. Embora na análise conjunta não tenham sido detectadas diferenças entre populações, estas ocorreram em parte das 
análises individuais, sendo no Anhembi - época normal e Caterpillar - safrinha para ARG na matéria seca e somente neste último para $A R G$ em percentual da proteína (dados não apresentados).

Os efeitos de ambientes foram significativos, exceto para TRE na matéria seca e FEN em percentual da proteína. Entre os fatores ambientais capazes de influenciar a composição química dos grãos estão fatores climáticos, de manejo da lavoura e de fertilidade do solo (East \& Jones, 1920; Oikeh, 1998).

Nos casos em que os efeitos de populações e de ambientes foram significativos, as estimativas dos componentes quadráticos mostraram que os efeitos de ambientes foram mais importantes que o de tratamentos para os seguintes caracteres: peso de espigas, teor de óleo, teor de fibras, MET, GLI, ALA, VAL, IE, LEU, TIR, FEN e CIS na matéria seca e MET, SER, PRO, GLI, ILE, LEU, CIS e ácido aspartico em percentual da proteína. Para SER, GLU e PRO na matéria seca e LIS em percentual da proteína houve forte predominância do efeito de populações (Tabelas 1, 2 e 3). As populações utilizadas neste trabalho representam um conjunto fixo de genótipos e a existência de variabilidade entre elas, com menor efeito de ambiente e da interação populações $x$ ambientes, representa uma maior segurança na seleção, principalmente quando há interesse de expandir a gama de ambientes de cultivo.

LIS é considerado o principal aminoácido limitante em milho e há grande interesse em aumentar o seu teor. A existência de diferenças e a predominância do efeito de populações revela potencial para a seleção de teores mais elevados. Também para os aminoácidos LEU, ILE e MET, de grande interesse para o melhoramento, houve variabilidade entre as populações avaliadas, o que não ocorreu para TRE. Entretanto, além da diversidade interpopulacional, as populações utilizadas neste trabalho possuem base genética ampla, sendo esperada variação intrapopulacional para os teores de aminoácidos, o que representa uma oportunidade adicional de seleção. 


\subsubsection{Médias}

O teor de proteína variou entre 10,51 e 11,58\%, o teor de óleo variou de 4,20 a $4,69 \%$ e teor de fibras, de 2,53 a 2,67\% (Tabela 4). Estes valores foram superiores à média de todas as análises já realizadas no Laboratório de Análises Físico-Químicas do CNPSA, que é de $8,68 \%$ para teor de proteína, 3,84\% para teor de óleo e 2,17\% para teor de fibras (EMBRAPA, 1991).

A população Composto GO-Flint se destacou em relação às demais por apresentar a maior média para teor de proteína e teor de óleo (Tabela 4). Além disso, foi incluída no grupo de maior média para a maioria dos aminoácidos, quando considerados na matéria seca (Tabela 5) e apresentou peso de espigas intermediário quando comparada aos demais tratamentos. Entretanto, apresentou o mais baixo valor para o teor de LIS em percentual da proteína (Tabela 6).

As médias de todas as populações foram superiores à da testemunha para teor de proteína, teor de óleo e para a maioria dos aminoácidos quando considerados com base na matéria seca (Tabelas 4 e 5). Para MET, apenas três das dez populações apresentaram média significativamente diferente da testemunha, e para LEU nove, sendo todas superiores à média da testemunha. Para ARG não houve diferenças entre as médias das populações e a da testemunha. Quando considerados com base na proteína total, apenas para TIR todas as populações apresentaram média superior à da testemunha (Tabela 6). MET, TRE, PRO, GLI, HIS e CIS apresentaram a maioria ou a totalidade das populações com médias inferiores à testemunha. Para SER, GLU e FEN algumas populações superaram a média da testemunha. Para o teor de fibras, as médias dos tratamentos não diferiram estatisticamente da testemunha. As diferenças marcantes detectadas em relação à testemunha quanto à composição de aminoácidos estão relacionadas a seu teor de proteína, que contrastou com o dos demais tratamentos por ser bem mais baixo. Em relação ao peso de espigas, considerando a média dos três ambientes, a maioria das populações apresentou desempenho semelhante ao da testemunha, sendo que a população $\mathrm{GN}-03$ foi significativamente superior. 


\subsubsection{Associação entre caracteres}

A metodologia de Spearman para as correlações foi empregada por estar livre das pressuposições de normalidade de ambos os conjuntos de dados a serem correlacionados (Steel \& Torrie, 1980). Assim, todas as correlações devem ser interpretadas com cuidado, devido ao pequeno número de observações empregadas nas estimativas e ao poder de teste reduzido desta metodologia em relação à de Pearson. A interpretação das correlações é limitada também ao intervalo de variação abrangido pelo trabalho para cada caráter. Deve-se ressaltar ainda que a interpretação das correlações neste trabalho, em um conjunto fixo de populações, pode diferir de estudos com conjuntos aleatórios de genótipos dentro de populações em equilíbrio.

Os resultados indicaram ausência de associações entre teor de proteína, teor de óleo e fibra bruta (Tabela 7). Da mesma forma, não houve qualquer associação entre o peso de espigas e os demais caracteres nas análises realizadas por ambiente (dados não apresentados). Em geral, têm sido detectadas correlações fenotípicas negativas entre produtividade e teor de proteína (Dudley \& Lambert, 1992; Corcuera \& Naranjo, 1995). Do mesmo modo, alguns trabalhos apontam a existência de correlações negativas entre teor de óleo e rendimento de grãos (Tatis, 1990). Porém, Alexander \& Lambert (1968) concluíram que a capacidade da planta produzir carboidratos e a de sintetizar óleo são fisiologicamente independentees no intervalo de 4 a $7 \%$ de óleo. Dorsey-Redding et al.(1991) e Séne et al.(2001) também não detectaram associação entre teor de proteína e teor de óleo, embora outros autores tenham obtido correlações positivas e, em alguns casos, de valor elevado (Song et al., 1999).

Os aminoácidos TRE, SER, GLU, PRO, ALA, ILE, LEU, TIR, FEN, HIS e ASP na matéria seca foram positivamente correlacionados ao teor de proteína, totalizando onze dos dezessete aminoácidos analisados (Tabela 7). Estas correlações variaram de 0,66 para PRO a 0,98 para GLU, indicando que maior percentual de proteína nos grãos representa um aumento proporcional nos teores daqueles aminoácidos. Os teores de LIS e MET não foram significativamente associados ao teor de proteína. Para outros conjuntos de genótipos, têm sido encontradas correlações 
positivas entre o teor de proteína e o de LIS na matéria seca (Miller et al., 1950; Sreeramulu \& Bauman, 1970), passando a negativas ou não significativas quando a LIS é considerada em percentual da proteína (Tello et al., 1965; Sreeramulu \& Bauman, 1970). O resultado diferenciado aqui obtido pode ter ocorrido devido ao conjunto fixo de genótipos utilizado e à reduzida variação entre genótipos para o teor de LIS. Alguns aminoácidos parecem estar associados aos teores de óleo, havendo correlações significativas e positivas deste com GLI e CIS.

Considerando os aminoácidos em percentual da proteína, apenas GLU foi positivamente correlacionado ao teor de proteína, enquanto LIS, MET, PRO, GLI, HIS, CIS e ASP foram negativamente correlacionados (Tabela 8). Isto significa que os genótipos com maior teor de proteína apresentaram menores proporções destes aminoácidos na composição da proteína, sendo condizente com resultados obtidos por outros autores e indesejável no caso de LIS e MET, aminoácidos considerados limitantes na alimentação de monogástricos e cuja proporção se deseja aumentar. A presença destas correlações sugere que um acompanhamento criterioso deve ser realizado durante a seleção, para que se possa obter concomitantemente quantidade e qualidade de proteína. Foi demonstrado que as zeínas, proteínas pobres em LIS, são a principal fração aumentada com a seleção para alto teor de proteína, o que explica a correlação negativa encontrada entre estes dois caracteres (Frey, 1951; Alexander et al., 1969; Nelson, 1969). Por outro lado, os aminoácidos TRE e ILE, cujas proporções se deseja aumentar, foram independentees do teor de proteína, assim como o aminoácido LEU, cuja proporção deve ser reduzida. Assim, não haveria dificuldade adicional para selecionar estes caracteres simultaneamente ao teor de proteína. Ainda considerando os aminoácidos em percentual da proteína, SER foi positivamente correlacionado com teor de óleo, enquanto ALA e LEU foram negativamente correlacionados a este; FEN foi positivamente correlacionado com fibra bruta. 


\subsubsection{Distância genética}

A análise de agrupamento a partir da distância euclidiana média (d) entre as populações permitiu a identeificação de quatro grupos de genótipos (Figura 1). O menor valor de d ocorreu entre as populações Composto GO Grosso e GN-02 $(0,32)$ e o maior valor foi entre as populações Composto GO Branco e GN-03 $(2,62)$ (Tabela 9). Estes valores são próximos aos obtidos por Cruz (1990), que variaram de 0,69 a 2,57, sendo que o autor citado escolheu populações com características bastante contrastantes e cujos híbridos apresentaram heterose para o rendimento de grãos.

O grupo I foi formado pelas populações Composto GO Grosso, Composto GO Longo, Composto GO Dente, GN-01 e GN-02. O grupo II foi formado pelas populações Composto GO Amarelo e GN-04. Formaram o grupo III as populaçõesComposto GO Flint e Composto GO Branco e o grupo IV a população GN-03 (Figura 1).

Embora apresentando a menor distância, as populações GN-02 e Composto GO Grosso não são aparentadas entre si. As populações GN-01 e GN-02 foram identeificadas como pertencentes ao mesmo grupo, embora tenham sido desenvolvidas como grupos heteróticos complementares (Nass \& Miranda Filho, 1999). Porém, a escolha dos genótipos para a formação destas populações se deu com base em caracteres agronômicos, principalmente a produtividade (Naspolini Filho et al., 1981; Santos et al., 1994), não sendo considerados aspectos relacionados à qualidade nutricional.

Devido à forma como foram originados os Compostos GO, era esperado que houvesse maior contraste nas combinações do Composto GO Flint com Dente, Amarelo com Branco e Longo com Grosso do que nas demais. Nos dois primeiros casos, as populações permaneceram em grupos separados, com d igual a 1,36 e 1,47, respectivamente. Entretanto, as populações Composto GO Longo e Composto GO Grosso ficaram no mesmo grupo e a distância entre elas foi igual a 0,74 , a sexta menor distância calculada. De maneira semelhante ao que foi discutido para os compostos GN, o critério utilizado para a formação destas populações não envolveu diretamente a qualidade nutricional. Os resultados descritos sugerem que os critérios de textura e coloração dos grãos podem estar associados à composição química, enquanto o diâmetro 
e o comprimento da espiga, utilizados para diferenciar entre o Composto GO Longo e Composto GO Grosso, não estão relacionados a esta.

\subsection{CONCLUSÕES}

As populações estudadas divergem para a maioria dos caracteres, indicando a possibilidade de seleção de genótipos com melhor qualidade nutricional. Os efeitos de ambiente influenciam a variação para a maior parte dos caracteres, ao contrário da interação genótipo-ambiente, permitindo a seleção para a média dos ambientes. Existe associação positiva entre proteína bruta e a maioria dos aminoácidos medidos, quando considerados na matéria seca, e negativa com muitos destes, quando considerados em percentual da proteína, o que demonstra que a composição de aminoácidos varia de acordo com o teor de proteína. Não houve associação entre qualidade nutricional e rendimento; portanto, não deve haver dificuldade na obtenção de cultivares de milho que reunam ambos os caracteres. Considerando os caracteres de maior importância para o melhoramento, foi possível definir quatro grupos de populações, com base na distância euclidiana média. 
Tabela 1. Análise de variância conjunta para os caracteres peso de espigas $(\mathrm{PE}, \mathrm{t} / \mathrm{ha})$, teor de proteína (PB), teor de óleo (EE) e teor de fibra (FB) em percentual da matéria seca. Média de três ambientes Piracicaba 1998/99.

\begin{tabular}{lcclc}
\hline F. V. & PE & PB & EE & FB \\
\hline Bloco/Ambiente & $0,5142^{*}$ & $0,5044^{* *}$ & 0,0585 & $0,0304^{* *}$ \\
Ambiente (A) & $48,1486^{* *}$ & $1,7082^{* *}$ & $3,9203^{* *}$ & $1,4161^{* *}$ \\
População (P) & $1,1683^{* *}$ & $0,5994^{* *}$ & $0,2377^{* *}$ & $0,0169^{*}$ \\
A x P & $0,5954^{* *}$ & 0,1416 & 0,0512 & $0,0158^{*}$ \\
Resíduo & 0,2866 & 0,1210 & 0,0586 & 0,0077 \\
& & & & \\
Média & 4,03 & 11,09 & 4,42 & 2,58 \\
C.V. & 13,29 & 3,13 & 5,47 & 3,39 \\
$\mathrm{R}^{2}$ & 0,76 & 0,72 & 0,82 & 0,91 \\
$\Phi_{\mathrm{a}}$ & 23,9310 & 0,0529 & 0,1287 & 0,0469 \\
$\Phi_{\mathrm{p}}$ & 0,0980 & 0,0532 & 0,0199 & 0,0010 \\
$\Phi_{\mathrm{pa}}$ & 0,0172 & 0,0069 & $-0,0024$ & 0,0027 \\
\hline
\end{tabular}

**,* significativo pelo teste $\mathrm{F}$ a 1 e $5 \%$ de probabilidade, respectivamente.

$\Phi_{\mathrm{a}} \Phi_{\mathrm{p}} \mathrm{e} \Phi_{\mathrm{pa}}$ componentes quadráticos associados aos efeitos de ambientes, populações e interação populações $\mathrm{x}$ ambientes, respectivamente 










Tabela 4. Médias dos tratamentos para os caracteres peso de espigas (PE), percentual de proteína (PB), percentual de óleo (EE) e percentual de fibra (FB). Média de três ambientes, Piracicaba 1998/99.

\begin{tabular}{lllll}
\hline Populações & PE & PB & EE & FB \\
\hline G & $5,88 \mathrm{ab}$ & $10,89 \mathrm{c}^{*}$ & $4,28 \mathrm{bc}^{*}$ & $2,58 \mathrm{ab}$ \\
$\mathrm{L}$ & $5,14 * \mathrm{bc}$ & $11,03 \mathrm{bc}^{*}$ & $4,20 \mathrm{c}^{*}$ & $2,55 \mathrm{ab}$ \\
$\mathrm{D}$ & $5,89 \mathrm{ab}$ & $11,20 \mathrm{abc}$ & $4,27 \mathrm{bc}^{*}$ & $2,56 \mathrm{ab}$ \\
$\mathrm{F}$ & $5,43 \mathrm{abc}$ & $11,58 \mathrm{a}^{*}$ & $4,69 \mathrm{a}^{*}$ & $2,53 \mathrm{~b}$ \\
$\mathrm{~B}$ & $5,51 \mathrm{abc}$ & $11,50 \mathrm{ab}^{*}$ & $4,40 \mathrm{abc} *$ & $2,67 \mathrm{a}$ \\
$\mathrm{A}$ & $5,37 \mathrm{abc}$ & $11,19 \mathrm{abc}^{*}$ & $4,55^{*} *$ & $2,62 \mathrm{ab}$ \\
$\mathrm{GN}-01$ & $5,04 * \mathrm{c}$ & $10,85 \mathrm{c}^{*}$ & $4,49 \mathrm{abc}$ & $2,55 \mathrm{ab}$ \\
$\mathrm{GN}-02$ & $5,67 \mathrm{abc}$ & $10,93 \mathrm{bc}^{*}$ & $4,30 \mathrm{ab} c^{*}$ & $2,65 \mathrm{ab}$ \\
GN-03 & $6,09 * \mathrm{a}$ & $10,81 \mathrm{c}^{*}$ & $4,62 \mathrm{a}^{*}$ & $2,54 \mathrm{~b}$ \\
GN-04 & $5,92 \mathrm{ab}$ & $10,94 \mathrm{bc}^{*}$ & $4,39 \mathrm{bc}^{*}$ & $2,64 \mathrm{ab}$ \\
$\mathrm{T}$ & 5,67 & 9,64 & 3,92 & 2,58 \\
\hline Médias seguidas da mesma letra não diferem significativamente pelo teste de Tukey a 5\% \\
*difere significativamente da média da testemunha pelo teste t a 5\% \\
G=Composto GO Grosso, L=Composto GO Longo, D=Composto GO Dente, F=Composto GO Flint, \\
B=Composto GO Branco, A=Composto GO Amarelo, T=testemunha (G-85)
\end{tabular}












Tabela 7. Correlações de Spearman entre percentual de proteína (PB), percentual de óleo (EE), percentual de fibra (FB) e os diferentes aminoácidos na matéria seca. Média de três ambientes, Piracicaba 1998/99.

\begin{tabular}{lccc}
\hline Caráter & PB & EE & FB \\
\hline PB & - & - & \\
EE & 0,03 & $-0,36$ & - \\
FB & 0,15 & $-0,40$ & $-0,45$ \\
LIS & $-0,59$ & 0,63 & 0,09 \\
MET & 0,47 & 0,43 & $-0,04$ \\
TRE & $0,80^{*}$ & 0,30 & 0,06 \\
SER & $0,90^{*}$ & 0,13 & 0,16 \\
GLU & $0,98^{*}$ & 0,56 & $-0,05$ \\
PRO & $0,66^{*}$ & $0,77^{*}$ & $-0,33$ \\
GLI & 0,41 & $-0,14$ & 0,07 \\
ALA & $0,95^{*}$ & 0,40 & $-0,02$ \\
VAL & 0,59 & 0,01 & 0,18 \\
ILE & $0,70^{*}$ & $-0,30$ & 0,20 \\
LEU & $0,82^{*}$ & $-0,22$ & $-0,01$ \\
TIR & $0,72^{*}$ & 0,01 & 0,26 \\
FEN & $0,79^{*}$ & 0,44 & 0,01 \\
HIS & $0,73^{*}$ & $-0,03$ & $-0,30$ \\
ARG & $-0,14$ & $0,65^{*}$ & 0,11 \\
CIS & 0,49 & 0,39 & $-0,19$ \\
ASP & $0,78^{*}$ & &
\end{tabular}

* Significativo a $5 \%$ de probabilidade 
Tabela 8. Correlações de Spearman entre percentual de proteína (PB), percentual de óleo (EE), percentual de fibra (FB) e os diferentes aminoácidos em percentual da proteína. Média de três ambientes, Piracicaba 1998/99.

\begin{tabular}{llll}
\hline Caráter & PB & EE & FB \\
\hline LIS & $-0,95^{*}$ & $-0,13$ & $-0,25$ \\
MET & $-0,98^{*}$ & 0,07 & $-0,08$ \\
TRE & $-0,41$ & 0,24 & $-0,16$ \\
SER & 0,49 & $0,65^{*}$ & $-0,22$ \\
GLU & $0,83^{*}$ & 0,20 & 0,30 \\
PRO & $-0,73^{*}$ & 0,20 & $-0,17$ \\
GLI & $-0,73^{*}$ & 0,20 & $-0,17$ \\
ALA & 0,02 & $-0,83^{*}$ & 0,24 \\
VAL & 0,07 & $-0,07$ \\
ILE & $-0,11$ & $-0,39$ & 0,25 \\
LEU & $-0,04$ & $-0,65^{*}$ & 0,47 \\
TIR & 0,47 & $-0,44$ & $-0,01$ \\
FEN & 0,14 & $-0,28$ & $0,64 *$ \\
HIS & 0,15 & 0,07 & $-0,08$ \\
ARG & $-0,98^{*}$ & $-0,19$ & $-0,09$ \\
CIS & $-0,39$ & 0,07 & $-0,08$ \\
ASP & $-0,98^{*}$ & 0,21 & $-0,32$ \\
\hline & $-0,72^{*}$ & 0,07 &
\end{tabular}

* Significativo a $5 \%$ de probabilidade 


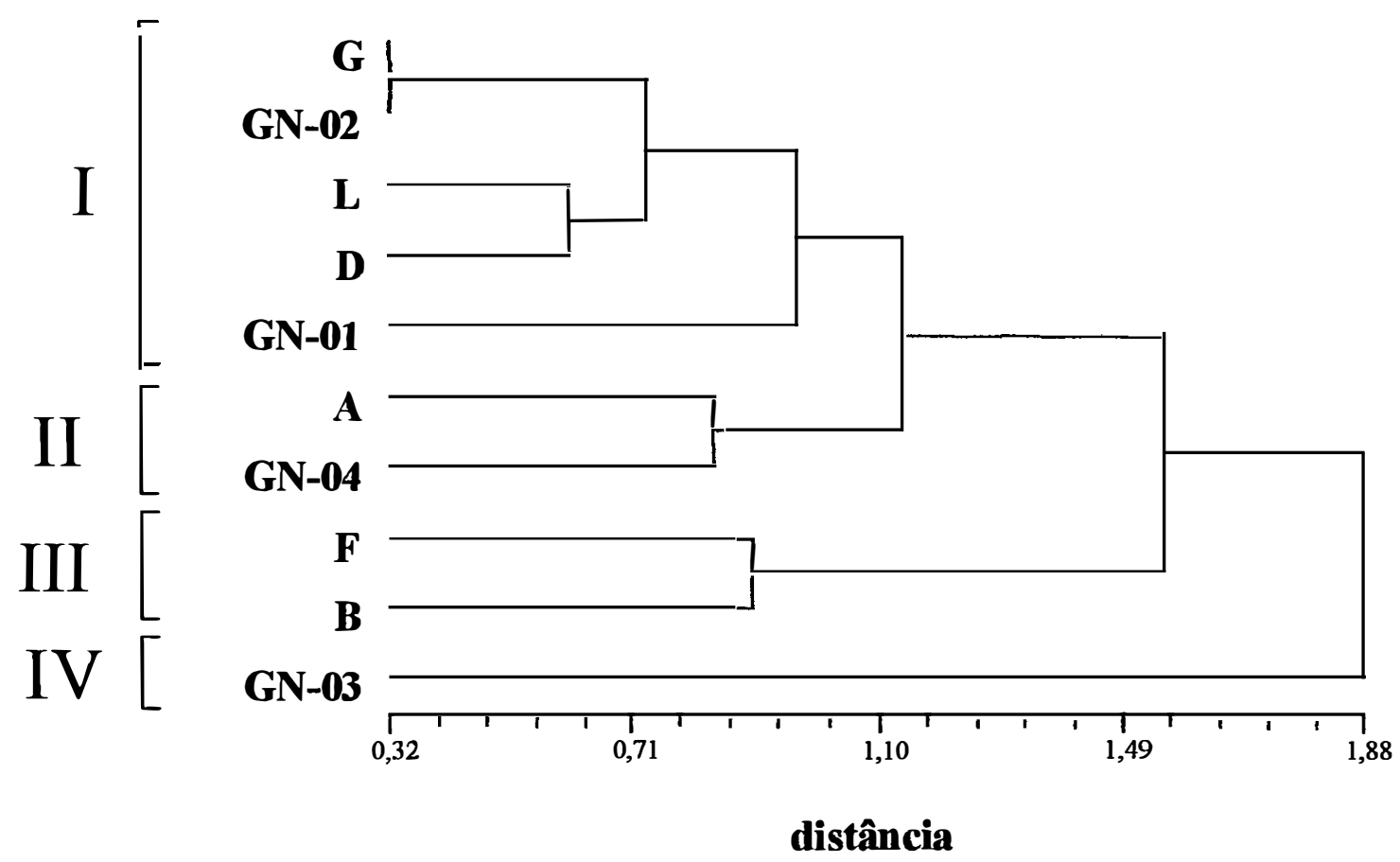

Figura 1- Dendrograma de agrupamento dos genitores a partir das estimativas da distância euclidiana média, Piracicaba, 1998/99. Correlação cofenética $r=$ 0,83 .

$\mathrm{G}=$ Composto GO Grosso, $\mathrm{L}=$ Composto GO Longo, $\mathrm{D}=$ Composto GO Dente, $\mathrm{F}=$ Composto GO Flint, $\mathrm{B}=$ Composto GO Branco, $\mathrm{A}=$ Composto GO Amarelo

Tabela 9. Distância euclidiana média (d) entre dez populações de milho, Piracicaba, 1998/99.

\begin{tabular}{lcccccccccc}
\hline & G & L & D & F & B & A & GN-01 & GN-02 & GN-03 & GN-04 \\
\hline G & - & & & & & & & & \\
L & 0,74 & - & & & & & & & \\
D & 0,73 & 0,61 & - & & & & & & \\
F & 1,93 & 1,69 & 1,36 & - & & & & & \\
B & 1,50 & 1,23 & 0,87 & 0,90 & - & & & & \\
A & 1,30 & 1,17 & 1,15 & 1,29 & 1,47 & - & & & \\
GN-01 & 0,71 & 1,21 & 1,12 & 1,91 & 1,79 & 1,09 & - & & \\
GN-02 & 0,32 & 0,75 & 0,71 & 1,82 & 1,36 & 1,23 & 0,84 & - & \\
GN-03 & 1,90 & 1,92 & 2,15 & 2,49 & 2,62 & 1,27 & 1,52 & 1,92 & - & 1,10 \\
GN-04 & 1,11 & 0,85 & 1,20 & 1,83 & 1,72 & 0,84 & 1,10 & 1,16 & 1,13 & - \\
G=Composto GO Grosso, L=Composto GO Longo, D=Composto GO Dente, F=Composto. GO Flint, \\
B=Composto GO Branco, A=Composto GO Amarelo
\end{tabular}




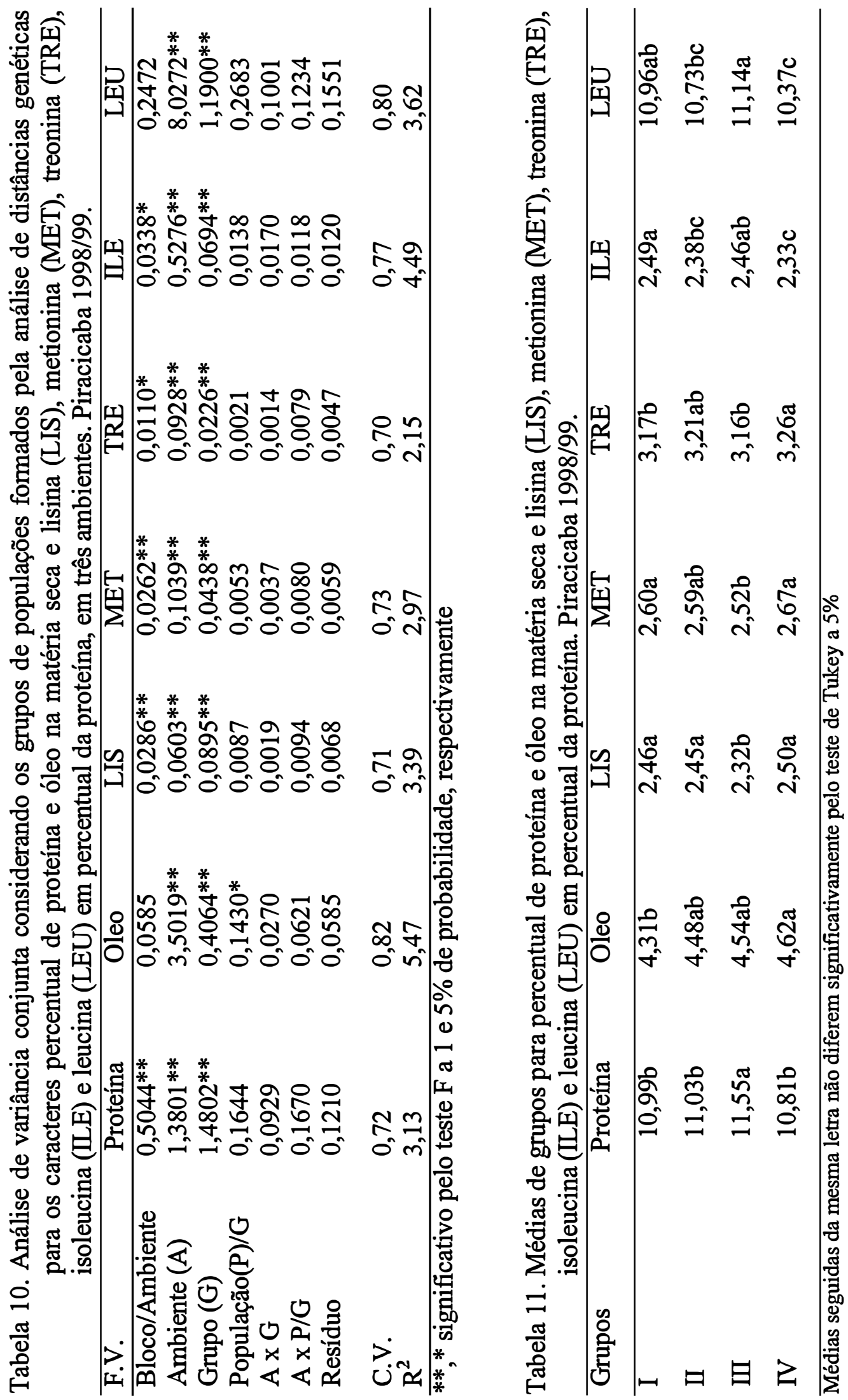




\section{AVAliaÇão do Potencial da populaÇão esazbB Para O MELHORAMENTO DE PROTEÍNA E ÓLEO ATRAVÉS DE TOPCROSS}

\section{RESUMO}

Entre as características capazes de adicionar valor comercial ao milho, estão as relacionadas à qualidade nutricional, com destaque para o teor de proteína e o teor de óleo, que possuem grande interesse para a indústria de rações. $\mathrm{O}$ objetivo deste trabalho foi verificar a variabilidade existente para os caracteres teor de proteína e teor de óleo, além da produtividade, em um conjunto de testcrosses. Foram avaliados os híbridos resultantes do cruzamento de 120 famílias $S_{1}$ da população ESA23B com dois testadores, sendo uma variedade de polinização aberta (BR108) e uma linhagem exótica (CML269). Os ensaios foram realizados em dois locais: Estação Experimental do Anhembi e Estação Experimental da Caterpillar, em Piracicaba (SP). O delineamento utilizado foi em blocos casualizados com três repetições. Foram avaliados os caracteres peso de espigas, peso de grãos, teor de proteína e teor de óleo. A interação tripla local $\mathrm{x}$ testador x progênie foi significativa, exceto para o teor de óleo. Assim, a seleção das progênies deve ser feita separadamente para cada experimento. Foi detectada diferença entre as progênies para todos os caracteres nas análises individuais, embora esta não tenha sido significativa na análise conjunta. As médias dos testcrosses variaram de $8,40 \%$ a $11,82 \%$ para teor de proteína e de $3,77 \%$ a $5,10 \%$ para teor de óleo. Híbridos com média semelhante ou superior à da melhor testemunha foram identificados para teor de proteína, peso de espigas e peso de grãos. As estimativas da variância aditiva interpopulacional, foram de 0,553 a 1,124 para o teor de proteína e de 0,034 a 0,057 para 
teor de óleo (dados em percentual). Em um dos experimentos, a estimativa de variância aditiva não foi significativamente diferente de zero para peso de espigas e para peso de grãos, variando nos demais experimentos de 362,83 a 521,74 para o primeiro caráter e de 212,40 a 381,73 para o segundo (dados em gramas por planta). Estes resultados, associados às estimativas de ganho genético, indicam que a população ESA23B possui potencial para o melhoramento dos quatro caracteres avaliados. As associações entre caracteres foram fracas, indicando a possibilidade de seleção simultânea para os caracteres de qualidade e rendimento entre os testcrosses.

\section{EVALUATION OF ESA23B POPULATION POTENTIAL TO PROTEIN AND OIL IMPROVEMENT THROUGH TOPCROSS}

\section{SUMMARY}

Among the traits that allow to add commercial value to maize, there are those related to nutritional quality, specially protein and oil content, that are of great interest to the feed industry. The objective of this work was to study variability to the traits protein and oil content, besides yield, in a group of testcrosses. $120 \mathrm{~S}_{1}$ families from ESA23B population were crossed with two testers, an open-pollinated population (BR108) and an exotic line (CML269). Testcrosses were evaluated at two locations: Experimental station of Anhembi and Experimental Station of Caterpillar (Piracicaba, SP), under the completely randomized block design with three replications. Ear yield, grain yield, protein content and oil content were evaluated. The three-way interaction location $x$ tester $\mathrm{x}$ progeny was significant, except for oil content; therefore, selection of the progenies must be made separately for each experiment. Differences among progenies were detected for all the traits in the individual analyses, although this effect has not been significant in the joint analysis. Testcross means varied from $8.40 \%$ to $11.82 \%$ for protein content and from $3.77 \%$ to $5.10 \%$ for oil content. Hybrids with means similar or superior to the best check were identified for protein content, ear yield, and grain yield. Estimates of the interpopulacional additive variance were from 0.553 to 1.124 for 
protein content and from 0.034 to 0.057 for oil content (percent data). In one of the experiments, additive variance estimates were not significantly different from zero for ear yield and grain yield, but in the others it varied from 362.83 to 521.74 and from 212.40 to 381.73 respectively (data in grams per plant). This results and genetic gain estimates indicate that ESA23B has potential to the improvement of the four evaluated traits. Associations among traits were weak, indicating possibility of simultaneous selection for quality traits and yield among the testcrosses. 


\subsection{INTRODUÇÃO}

Durante muito tempo, o melhoramento de milho concentrou esforços no aumento da produtividade. Outras características diretamente relacionadas à produtividade, como arquitetura de planta e resistência a pragas e doenças, também foram priorizadas, atendendo às necessidades dos produtores de milho. Porém, tendo em vista que a principal utilização do milho no Brasil é na alimentação animal, na forma de rações, existe a possibilidade de adicionar valor ao produto, procurando desenvolver cultivares que atendam às necessidades dos demais segmentos de mercado relacionados à cadeia de utilização do milho. Entre as características de interesse deste mercado, podem ser destacadas características relacionadas à qualidade nutricional dos grãos, com destaque para o teor de proteína e teor de óleo.

$\mathrm{O}$ teor de proteína é um caráter quantitativo e diversos estudos têm apontado para um grande número de genes envolvidos em seu controle. Dudley \& Lambert (1992) estimaram em 173 o número de genes afetando este caráter. Em um estudo de QTLs envolvendo 80 marcadores regularmente espaçados no genoma, dezesseis marcadores agrupados em oito regiões estiveram associados ao teor de proteína (Berke \& Rocheford, 1995). Tanto efeitos aditivos como não aditivos são importantes no controle do caráter, sendo que a dominância ocorre essencialmente no sentido da redução do caráter (East \& Jones, 1920; Sreeramulu \& Bauman, 1970; Berke \& Rocheford, 1995).

Efeitos de ambiente e da interação genótipo $\mathrm{x}$ ambiente significativos são, em geral, detectados para o teor de proteína (Genter et al., 1956; Berke \& Rocheford, 1995). Entre os fatores de ambiente que influenciam o teor de proteína destacam-se a temperatura e a disponibilidade de água e nitrogênio no solo (East \& Jones, 1920; Oikeh, 1998). Do ponto de vista da variação genética, o genótipo da planta em que a espiga se desenvolve é o principal determinante do teor de proteína, sendo que o genótipo do pólen não afeta significativamente a proteína nos grãos (East \& Jones, 1920; Letchworth \& Lambert, 1998).

A existência de variabilidade e possibilidade de seleção para o conteúdo de proteína em milho tem sido demonstrada em diversos estudos (Dudley, 1977; Dudley \& 
Lambert, 1992; Micu et al., 1995). Em um experimento clássico, iniciado por Hopkins em 1896, a população Burr's White foi selecionada em direções opostas, para alto (IHP) e baixo (ILP) teor de proteína. Após setenta e seis gerações de seleção massal, o aumento no teor de proteína era de $139 \%$, ou 20 vezes o desvio padrão da população original, sem que a variabilidade genética para este caráter houvesse sido exaurida (Dudley, 1977). Após 90 gerações de seleção foi realizado o cultivo, no mesmo experimento, de populações representando os últimos 25 ciclos. O ganho médio por ciclo de seleção foi de $0,13 \pm 0,02$ pontos percentuais (Dudley \& Lambert, 1992). Em outro trabalho, foram identificadas amostras com alto teor de proteína (12-15\%) entre populações locais da Moldávia. Após 12 anos de seleção recorrente, progênies com até $23-24 \%$ de proteína foram obtidas, sem que a variabilidade genética fosse esgotada (Micu et al., 1995).

O teor de óleo nos grãos de milho também é um caráter quantitativo (Dudley, 1977). Berke \& Rocheford (1995) detectaram 31 locos de RFLP associados ao teor de óleo; entretanto, sete destes responderam por $61 \%$ da variação genotípica total para teor de óleo, mesmo se tratando de um cruzamento entre genótipos extremamente divergentes. Da mesma forma, o teor de óleo parece ser menos influenciado pelos efeitos de ambiente e da interação genótipo x ambiente que o teor de proteína (Genter et al., 1956; Berke \& Rocheford, 1995).

A variância genética aditiva parece ser o principal componente no controle deste caráter (Dudley, 1977). O controle maternal, ou seja, a influência do genótipo da planta mãe, é apontado como o efeito predominante na determinação do conteúdo de óleo nos grãos (Miller \& Brimhall, 1951; Garwood et al., 1970; Batista \& Tosello, 1982). Porém, também ocorre influência do genótipo paterno, através do efeito de xênia (Miller \& Brimhall, 1951; Alexander \& Lambert, 1968; Letchworth \& Lambert, 1998).

Diversos trabalhos têm comprovado a eficiência da seleção recorrente para 0 aumento do teor de óleo (Misevic \& Alexander, 1989; Dudley \& Lambert, 1992; Song et al., 1999). Em um experimento conduzido na Universidade de Illinois, com 90 ciclos de seleção, a população denominada IHO (Illinois High Oil) teve um aumento de 4,7\% para $19,3 \%$ no teor de óleo, representando um ganho de aproximadamente 22 vezes o desvio 
padrão aditivo da população original. $\mathrm{O}$ ganho médio por ciclo de seleção foi de $0,14 \pm 0,02$ pontos percentuais e o número de genes contribuindo para o caráter foi estimado em 69 (Dudley \& Lambert, 1992). A seleção de grãos individuais foi empregada na população Zhongzong $\mathrm{n}^{\circ} .2$, permitindo atingir $11,25 \%$ de óleo após onze ciclos de seleção, o que correspondia a 2,39 vezes a média ou 8,6 vezes o desvio padrão da população original (Song et al., 1999). Da mesma forma, 24 ciclos de seleção na população Alexho Synthetic permitiram um aumento no teor de óleo de $5 \%$ para $17 \%$, ou seja, 0,49 pontos percentuais por ciclo (Misevic \& Alexander, 1989). Em nenhum dos trabalhos citados houve sinal de esgotamento da variabilidade genética para o caráter.

O esquema topcross foi proposto por Davis (1927) e Jenkins \& Brunson (1932) e é hoje amplamente utilizado tanto para o desenvolvimento de novas combinações híbridas, como em esquemas de seleção recorrente (Miranda Filho \& Gorgulho, 2001). Este esquema de seleção permite avaliar progênies de uma população quanto a sua capacidade de combinação com um testador. Tem sido demonstrado que, em programas de seleção recorrente para posterior extração de linhagens, a seleção com base no esquema topcross é superior à seleção entre famílias intrapopulacionais quando existe dominância para o caráter (Holthaus \& Lamkey, 1995).

Assim, o objetivo deste trabalho foi verificar a variabilidade genética existente para os caracteres teor de proteína e teor de óleo, além da produtividade, em um conjunto de híbridos resultantes do cruzamento de famílias $S_{1}$ da população ESA23B com dois testadores.

\subsection{MATERIAL E MÉTODOS}

A população ESA23B, de endosperma branco, vem sendo selecionada pelo Programa de Melhoramento de Milho da ESALQ/USP, apresentando boa adaptação e bom desempenho quanto a caracteres agronômicos. Neste experimento, 120 famílias $S_{1}$ derivadas desta população foram testadas em topcross com uma variedade de polinização aberta (BR108) e uma linhagem endogâmica exótica (CML269), 
proveniente do CIMMYT (Centro Internacional de Melhoramento de Milho e Trigo, México).

\subsubsection{Condução do experimento}

Os cruzamentos foram realizados na área experimental da Escola Superior de Agricultura "Luiz de Queiroz", em Piracicaba na safra de 1998/1999. As famílias $S_{1}$ foram utilizadas como genitores femininos, sendo semeadas duas linhas de três metros de comprimento de cada família, com espaçamento entre linhas de $0,9 \mathrm{~m}$ e entre plantas na linha de $0,2 \mathrm{~m}$. Pelo menos cinco espigas de cada família foram polinizadas manualmente com cada um dos testadores. Foram obtidos 113 testcrosses para cada testador, sendo que algumas progênies diferem entre os testadores.

No verão de 1999/2000 os híbridos resultantes do topcross foram avaliados em ensaios de campo. $\mathrm{O}$ delineamento utilizado foi em blocos casualizados com três repetições, em parcelas compostas por uma linha com $4 \mathrm{~m}$ de comprimento, sendo o espaçamento entre linhas de $0,9 \mathrm{~m}$ e entre plantas de $0,2 \mathrm{~m}$. Os ensaios foram realizados em dois locais: Estação Experimental do Anhembi e Estação Experimental da Caterpillar, em Piracicaba (SP). As testemunhas Master (Novartis) e BR2121 (EMBRAPA) foram inseridas de maneira sistemática, a cada dez parcelas dos testcrosses. Master é um híbrido triplo de endosperma normal e BR2121 é um híbrido duplo do tipo QPM (Quality Protein Maize) contendo o gene mutante opaco-2 (o $\left.o_{2}\right)$. Em parcelas intercaladas da testemunha BR2121 (uma a cada vinte parcelas de testcrosses) cinco espigas foram polinizadas manualmente, com pólen da própria testemunha, a fim de garantir a expressão do gene recessivo $o_{2}$. Nestas parcelas, foram colhidas apenas as espigas polinizadas manualmente.

O rendimento de espigas (peso de espigas) e de grãos (peso de grãos) por parcela foi avaliado, sendo corrigido para o estande ideal de 20 plantas por parcela, pelo método da covariância. As médias são apresentadas em $\mathrm{kg} / \mathrm{ha} \mathrm{e}$ as variâncias em gramas por planta $(\mathrm{g} / \mathrm{pl})$, mantendo as unidades mais utilizadas na literatura, a fim de facilitar as comparações. 


\subsubsection{Avaliação de proteína e óleo}

Após a debulha, foi retirada uma amostra de $50 \mathrm{~g}$, representativa de cada parcela, para realização das análises químicas. As análises de proteína e óleo foram realizadas no Laboratório de Análises Físico-Químicas do Centro Nacional de Pesquisa de Suínos e Aves da Empresa Brasileira de Pesquisa Agropecuária (EMBRAPA/CNPSA), em Concórdia, SC.

As amostras foram moídas em um moinho de faca refrigerado Knifetec 1095 (Tecator) após os grãos terem sido quebrados em um moinho de disco Cemotec 1090 (Tecator). As análises foram feitas através da metodologia NIR (near infrared reflectance spectroscopy), utilizando um instrumento NIRSystem 6500 cujas curvas de calibração foram desenvolvidas no próprio laboratório, especialmente para este experimento. A metodologia empregada para obtenção das curvas de calibração utilizou procedimentos recomendados pela Association of Official Analytical Chemists (AOAC, 1995): para matéria seca, secagem em estufa a $105^{\circ} \mathrm{C}$ de um dia para o outro; para proteína bruta, método Kjeldahl; para óleo, extração em éter utilizando aparelho Soxhlet. Os dados de proteína e óleo foram corrigidos, sendo considerados com base na matéria seca.

As estimativas de parâmetros para a avaliação das curvas de calibração são apresentadas na Tabela 1. Após a calibração, mais 20 amostras foram analisadas em laboratório e os valores obtidos foram comparados aos preditos através do NIR. A correlação entre os resultados de ambos os métodos foi de 0,96 para teor de proteína e 0,71 para teor de óleo.

\subsubsection{Análises estatístico-genéticas}

Inicialmente, foram realizadas as análises de variância individuais para cada experimento, representando cada combinação de testador e local. Os quadrados médios do resíduo dos experimentos foram considerados semelhantes, permitindo a realização da análise conjunta. Também foram realizadas análises conjuntas por local e por 
testador. Os efeitos de local e de testador foram considerados fixos e o de progênies, aleatório.

Nas análises de variância individuais, os quadrados médios referentes a testcrosses $\left(\mathrm{Q}_{1}\right)$ e erro $\left(\mathrm{Q}_{2}\right)$ têm as seguintes esperanças matemáticas: $\mathrm{E}\left(\mathrm{Q}_{1}\right)=\sigma^{2}+r \sigma_{\mathrm{t}}^{2}$ e $E\left(Q_{2}\right)=\sigma^{2}$, sendo $\sigma^{2}$ a variância do erro experimental e $\sigma_{t}^{2}$ a variância genética entre testcrosses. Esta é definida ao nível interpopulacional e é função de um dos homólogos da variância aditiva interpopulacional, ou seja, $\sigma_{t}^{2}=[(1+F) / 4] \sigma_{A 12}^{2}$, sendo $F$ o coeficiente de endogamia nas famílias. No presente estudo tem-se $F=0$ nas famílias $S_{1}$. Deste modo, é obtida a estimativa $\hat{\sigma}_{\mathrm{Al2}}^{2}=4 \hat{\sigma}_{\mathrm{t}}^{2}$, em que $\hat{\sigma}_{\mathrm{A} 12}^{2}$ se refere à população não endógama, ou seja, genótipos $\mathrm{S}_{0}$ e testador. Em termos de estrutura populacional, considerando um loco com dois alelos, $\sigma_{A 12}^{2}=2 p(1-p)[a+(1-2 t) d]^{2}$, sendo $p$ a freqüência do alelo favorável na população base, $\mathrm{t}$ a freqüência do mesmo alelo no testador, a a metade da diferença entre os valores genotípicos dos homozigotos e d um desvio de dominância (Miranda Filho \& Gorgulho, 2001).

Também foi estimado o ganho de seleção, o qual será apresentado em valor absoluto, na unidade de medida do caráter (Gs), e em percentual da média geral dos testcrosses (Gs\%). A sensibilidade dos experimentos em diferenciar os efeitos dos testcrosses foi comparada pelo teste de Schumann \& Bradley (1959), com base nos valores do teste $F$ para o efeito de progênies.

As médias das progênies foram comparadas entre si pelo teste de Scott-Knott e com a média da melhor testemunha pelo teste $t$, ambos a $5 \%$ de probabilidade. Correlações fenotípicas entre os caracteres foram estimadas para cada experimento. 


\subsection{RESULTADOS E DISCUSSÃO}

Houve diferença significativa entre as progênies para todos os experimentos e caracteres estudados, exceto peso de espigas no experimento envolvendo o testador BR108 no Anhembi (Tabela 2). Algumas falhas no controle de plantas daninhas, detectadas apenas neste experimento, contribuíram para elevar o erro experimental, dificultando a identificação das diferenças entre tratamentos. Isso refletiu também em um coeficiente de variação mais elevado que os dos demais experimentos, tanto para peso de espigas como para peso de grãos.

$\mathrm{Na}$ análise conjunta, o efeito da interação tripla envolvendo locais, testadores e progênies foi significativo para todos os caracteres, exceto teor de óleo (Tabela 3). Assim, os demais resultados foram obtidos separadamente por experimento, ou seja, por testador e local. $\mathrm{O}$ estudo de correlações de Spearman comparando a classificação das progênies nos quatro experimentos demonstrou também a existência de interação genótipo $\mathrm{x}$ ambiente do tipo complexa, ou seja, devida a mudanças na ordem de classificação dos genótipos (dados não apresentados). $\mathrm{Na}$ maioria dos casos estas correlações foram extremamente baixas e não significativas. Da mesma forma, nas análises conjuntas por local, houve significância da interação testador $x$ progênie (Tabela 4). Nas análises conjuntas por testador, a interação local $x$ progênie foi significativa, exceto para teor de óleo (Tabela 5). A presença deste tipo de interação dificulta a seleção das progênies que serão recombinadas a fim de dar origem a um novo ciclo de seleção recorrente. Apenas o caráter teor de óleo poderia ser selecionado com base na média dos dois locais, porém considerando cada testador em separado.

O efeito de testadores foi significativo na análise conjunta por local, exceto para o teor de proteína, sendo o testador CML269 o que apresentou as maiores médias (Tabelas 4 e 6). A análise conjunta por testador evidenciou a importância do efeito de local. O ambiente da Estação Experimental da Caterpillar foi mais favorável, apresentando maiores médias para todos os caracteres (Tabelas 5 e 6). A maior heterose obtida nos cruzamentos envolvendo CML 269 pode ser explicada por se tratar de uma linhagem endogâmica e, por ser exótica, provavelmente mais divergente da população 
ESA23B que o testador BR108. O efeito de progênies não foi significativo na análise conjunta, refletindo o fato de que as diferenças detectadas nas análises individuais não foram uniformes para todos os experimentos.

\subsubsection{Médias}

A comparação de médias entre as testemunhas demonstrou que, em todos os experimentos, a testemunha BR2121 com polinização controlada (pólen do mesmo genótipo) foi superior para percentual de proteína e de óleo (Tabela 6). Em geral, houve diferença também entre BR2121 com polinização livre e Master. Para o peso de espigas e peso de grãos, foram consideradas apenas as testemunhas BR2121 com polinização livre e Master, sendo esta significativamente superior para peso de espigas em dois experimentos e para peso de grãos em todos os experimentos. A média e os valores mínimos e máximos alcançados pelos testcrosses para cada experimento são igualmente apresentados na Tabela 6. A testemunha BR2121 é um híbrido duplo do tipo QPM, possuindo o gene mutante $o_{2}$, que além de maior teor de lisina e triptofano, provoca um aumento no tamanho do embrião e, consequentemente, no teor de óleo do grão. Quanto a teor de proteína e produtividade, há grande variação de comportamento entre os genótipos QPM.

As médias dos testcrosses para proteína variaram, entre experimentos, de $8,40 \%$ a $11,82 \%$, sendo que a maior parte deles ficou acima da média de todos os experimentos já realizados no mesmo laboratório (EMBRAPA, 1991). As médias obtidas em experimentos na região de Piracicaba foram de 9,82\% (Composto braquítico VD opaco, Zimback, 1985) e (IG-1 e IG-2, Garcia, 1998). A menor média calculada para teor de óleo foi 3,77\% e a maior 5,10\%. A média de 266 análises de milho de diferentes origens foi de 3,84\% (EMBRAPA, 1991). Silva (1990) observou médias de 4,79\% (Piranão VD-2) e 5,06\% (Piranão VF-1). Na população ESALQ VD-2, foram obtidas médias de 5,38\%, em espigas autofecundadas (Batista, 1980).

A média de cada testcross foi comparada pelo teste $t$ à melhor testemunha, para cada caráter e experimento (Tabela 7 e Anexos). Para proteína, de 20 a $80 \%$ dos 
testcrosses apresentaram média semelhante à da melhor testemunha. Alguns híbridos superiores à melhor testemunha para teor de proteína foram obtidos, sendo $1,8 \%$ dos híbridos no experimento com o testador CML269 no Anhembi, $14 \%$ no experimento com o testador BR108 na Caterpillar e 18\% no experimento com o testador CML269 na Caterpillar. Para o caráter percentual de óleo, não foram detectados híbridos com média superior ou semelhante à da melhor testemunha. É importante ressaltar que a testemunha BR2121 é um genótipo de alta qualidade nutricional que, neste trabalho, apresentou de 0,95 a 1,46 pontos percentuais ( 22 a $31 \%$ ) acima da outra testemunha para teor de óleo. Esta testemunha chegou a superar o valor de $6 \%$ de percentual de óleo, considerado como critério mínimo para inclusão na categoria de Milho Alto Óleo (US Grain Council, 2000), sendo um padrão dificil de ser alcançado na ausência de seleção específica para o caráter. Em média, os testcrosses foram semelhantes à testemunha Master para o teor de óleo. Vários testcrosses com média semelhante à da melhor testemunha foram detectados, tanto para peso de espigas (18 a $31 \%$ dos testcrosses, conforme o experimento), como para peso de grãos (11 a $26 \%$ ).

\subsubsection{Variância aditiva interpopulacional e ganho genético}

A capacidade de discriminação entre progênies de cada um dos experimentos foi comparada pelo teste de Schumann \& Bradley (1959), representando diferenças de sensibilidade entre os experimentos (Tabela 8). Assim, para percentual de proteína, o experimento com testador CML269 na Caterpillar apresentou maior capacidade de discriminação entre as progênies. Para percentual de óleo, este foi o experimento de menor sensibilidade, sendo o melhor o que envolveu o testador BR108 na Caterpillar. Para peso de espigas e peso de grãos, o testador BR108 no Anhembi apresentou menor sensibilidade que todos os demais experimentos. A relação de magnitude entre as estimativas da variância aditiva interpopulacional correspondeu a estas diferenças (Tabela 8).

As estimativas de variância aditiva interpopulacional foram significativas, exceto para peso de espigas e peso de grãos no experimento com o testador BR108 no 
Anhembi (Tabela 8). De maneira geral, as estimativas de variância aditiva para teor de óleo foram baixas $(0,034$ a 0,057 , para dados em percentual), em comparação com os valores encontrados na literatura, podendo indicar um baixo potencial para o melhoramento deste caráter na população ESA23B. Estes valores são bastante próximos ao obtido para a população Piranão VF-1, que foi de 0,049 (Silva, 1990). As demais estimativas obtidas para populações brasileiras de milho variam entre 0,079 e 1,352, para dados em percentual (Bianco, 1984; Zimback, 1985; Zanotto, 1986; Silva, 1990). Entretanto, as estimativas obtidas pelos citados autores referem-se a famílias intrapopulacionais, dificultando a comparação. Além disso, foi demonstrado que o teor de óleo sofre efeito de xênia (Miller \& Brimhall, 1951; Alexander \& Lambert, 1968; Letchworth \& Lambert, 1998). Assim, sua avaliação em sementes de polinização livre tende a reduzir as diferenças entre testcrosses, uma vez que ocorre no campo a mistura de pólen de todos os tratamentos do experimento. A variação para o teor de proteína, considerando se tratar da mesma unidade de medida, foi mais elevada. Os valores foram superiores aos obtidos por Zimback (1985) para duas subpopulações do Composto braquítico VD opaco $(0,57$ e 0,55 , para dados em percentual) e também aos estimados por Tosello e Geraldi (1980) para a população ESALQ VD opaco $(0,31)$. Este fato, associado à deteç̧ão de algumas famílias com teor de proteína superior ao da melhor testemunha, indica um grande potencial desta população para o melhoramento do caráter. As estimativas obtidas para os caracteres peso de espigas e peso de grãos indicam a possibilidade de seleção adicional para produtividade.

Estudos teóricos sugeriram que o melhor testador seria uma linhagem homozigota recessiva ou uma população com baixa freqüência alélica para os locos mais importantes (Allison e Curnow, 1996). Diversos autores obtiveram maior sucesso na seleção com o uso de linhagens endogâmicas e de baixo valor per se para os caracteres de interesse (Horner et al., 1973; Charcosset et al., 1990). O testador BR108 é uma variedade de polinização aberta, produtiva e adaptada às condições brasileiras, enquanto CML269 é uma linhagem endogâmica exótica. Porém, este fato não parece ter sido determinante para a capacidade dos testadores em diferenciar os testcrosses. É provável que, para os caracteres peso de espigas e peso de grãos, a não significância da estimativa 
de variância aditiva interpopulacional obtida para o experimento com o testador BR108 no Anhembi tenha ocorrido em função do erro experimental proporcionalmente mais elevado, devido aos problemas citados anteriormente.

O ganho genético esperado, ou ganho de seleção, foi estimado tomando por base uma intensidade de seleção de $10 \%$. Esta intensidade de seleção foi escolhida a fim de facilitar a comparação com os dados existentes na literatura. Porém, considerando o número de progênies utilizadas, seria mais adequado utilizar uma seleção menos intensa para não reduzir excessivamente o tamanho efetivo da população, o que tenderia a reduzir os ganhos ao longo dos próximos ciclos de seleção recorrente. Deve ser ressaltado, ainda, que o ganho genético aqui estimado se refere ao híbrido interpopulacional. Em termos percentuais, as mais altas estimativas de ganho genético foram para os caracteres de produtividade, chegando $11,32 \%$ para peso de grãos no experimento com o testador CML 269 no Anhembi (Tabela 8). Deve ser ressaltado que o ganho genético aqui estimado se refere ao híbrido interpopulacional.

As estimativas do ganho genético para teor de proteína variaram de 4,07 a $8,97 \%$, representando, em termos absolutos, 0,40 a 0,93 pontos percentuais. Estes ganhos são semelhantes aos relatados por Woodworth (1952) para cinco ciclos de um esquema de seleção recorrente intrapopulacional, que foi de 5,2\%. Zimback (1985) calcularam ganhos esperados de seleção para o teor de proteína de 5,65 e 6,44\% para duas subpopulações. As estimativas mais baixas do ganho genético ocorreram para o teor de óleo (Tabela 8). Mesmo assim, ganhos de 1,83 a 3,56\% são esperados no primeiro ciclo de seleção, o que corresponde, em termos absolutos, a 0,09 e 0,16 pontos percentuais. Em termos absolutos, estes valores são semelhantes ao obtido para a população IHO e inferiores ao da população Zhongzong n.2 (Dudley e Lambert, 1992; Song et al., 1999). Em termos percentuais, estes ganhos são superiores aos obtidos por Batista (1980) em resposta à seleção para tamanho de embrião. Mais uma vez, é necessária a ressalva de que os ganhos relatados na literatura foram estimados para diferentes métodos de seleção intrapopulacional, ao contrário dos obtidos neste trabalho. 


\subsubsection{Associações entre caracteres}

A análise de correlações fenotípicas permitiu detectar associações entre alguns dos caracteres estudados (Tabela 9). Conforme esperado, os caracteres peso de espigas e peso de grãos foram fortemente correlacionados. Os caracteres percentual de proteína e percentual de óleo estiveram significativamente correlacionados em todos os experimentos, embora com valores baixos, variando de 0,21 a 0,41 . 0 caráter percentual de óleo esteve ainda significativamente correlacionado com peso de espigas e peso de grãos, porém apenas nos experimentos envolvendo o testador BR108 e com valores igualmente baixos. $\mathrm{Na}$ literatura, as associações entre teor de proteína e teor de óleo têm variado de não significativas (Dorsey-Redding et al.,1991; Séne et al., 2001) a valores positivos elevados (Song et al., 1999). Correlações negativas entre teor de óleo e produtividade em milho são freqüentemente encontradas na literatura, sugerindo uma dificuldade na seleção simultânea para ambos os caracteres (Misevic e Alexander, 1989; Tatis, 1990; Dudley e Lambert, 1992). Por outro lado, Alexander e Lambert (1968) concluíram que a capacidade da planta produzir carboidratos e a de sintetizar óleo são fisiologicamente independentes no intervalo de 4 a $7 \%$ de óleo. Entretanto, as associações aqui encontradas ocorrem em sentido favorável, o que tende a facilitar a seleção simultânea para os caracteres de qualidade e de rendimento entre os testcrosses. As medidas de correlação aqui apresentadas têm como base os híbridos testcrosses (família $S_{1} \times$ testador) e podem eventualmente diferir de estimativas do coeficiente de correlação entre genótipos dentro de populações em equilíbrio. 


\subsection{CONCLUSÕES}

Existe variabilidade na população ESA23B para os caracteres estudados; porém a classificação das progênies é influenciada pelo testador utilizado e pelo local, devendo a seleção ser feita para cada experimento separadamente. As estimativas da variância aditiva interpopulacional e do ganho genético indicam que existe potencial para o melhoramento dos quatro caracteres avaliados. As associações entre caracteres foram fracas e em sentido favorável, indicando a possibilidade de seleção simultânea para os caracteres de qualidade e rendimento entre os testcrosses. 
Tabela 1. Caracterização das equações de calibração para a análise de teor de matéria seca, proteína e óleo através da refletância no infravermelho próximo em grãos de milho moídos.

\begin{tabular}{lccccc}
\hline Variável & $\mathrm{N}$ & $\mathrm{SEC}$ & $\mathrm{R}^{2}$ & $\mathrm{SECV}$ & $\mathrm{R}_{1}{ }^{2}$ \\
\hline 1. Matéria seca & 115 & 0,28 & 0,80 & 0,32 & 0,74 \\
2. Proteína & 117 & 0,14 & 0,96 & 0,19 & 0,94 \\
3. Óleo & 103 & 0,17 & 0,75 & 0,28 & 0,52 \\
\hline
\end{tabular}

$\mathrm{n}=$ numero de amostras utilizadas na calibração

$\mathrm{SEC}=$ erro padrão da calibração

$\mathbf{R}^{2}=$ coeficiente de determinação da regressão dos valores de laboratório sobre os dados de refletância $\mathrm{SECV}=$ erro padrão da validação

$\mathrm{R}_{1}{ }^{2}=$ coeficiente de determinação da validação 
Tabela 2. Análises de variância por experimento para os caracteres teor de proteína (\%), teor de óleo (\%), peso de espigas (PE, g/pl) e peso de grãos (PG, g/pl). Dois testadores e dois locais, Piracicaba, 1999/2000.

\begin{tabular}{|c|c|c|c|c|c|c|c|c|}
\hline \multirow[t]{3}{*}{ F.V. } & \multicolumn{4}{|c|}{ Anhembi } & \multicolumn{4}{|c|}{ Caterpillar } \\
\hline & \multicolumn{2}{|c|}{ BR108 } & \multicolumn{2}{|c|}{ CML269 } & \multicolumn{2}{|c|}{ BR108 } & \multicolumn{2}{|c|}{ CML269 } \\
\hline & g.l. & QM & g.l. & QM & g.1. & QM & g.l. & QM \\
\hline \multicolumn{9}{|l|}{ PROTENAA } \\
\hline Bloco & 2 & $2,54^{* *}$ & 2 & $3,42 * *$ & 2 & $1,99 * *$ & 2 & 0,19 \\
\hline Topcross & 112 & $0,87^{* *}$ & 112 & $0,88^{* *}$ & 112 & $0,62 * *$ & 112 & $0,94^{* *}$ \\
\hline Erro & 186 & 0,44 & 190 & 0,38 & 191 & 0,24 & 191 & 0,18 \\
\hline C.V. & & 6,88 & & 6,27 & & 4,78 & & 4,04 \\
\hline $\mathbf{R}^{2}$ & & 0,56 & & 0,60 & & 0,61 & & 0,76 \\
\hline \multicolumn{9}{|l|}{ ÓLEO } \\
\hline Bloco & 2 & 0,048 & 2 & $1,111^{* *}$ & 2 & 0,037 & & 0,027 \\
\hline Topcross & 112 & $0,060^{* *}$ & 112 & $0,052 * *$ & 112 & $0,059 * *$ & 112 & $0,050^{* *}$ \\
\hline Erro & 186 & 0,030 & 190 & 0,024 & 191 & 0,020 & 191 & 0,027 \\
\hline C.V. & & 4,08 & & 3,49 & & 3,20 & & 3,52 \\
\hline $\mathbf{R}^{2}$ & & 0,55 & & 0,64 & & 0,64 & & 0,52 \\
\hline \multicolumn{9}{|l|}{$\mathrm{PE}$} \\
\hline Bloco & 2 & $3731,84^{* *}$ & 2 & $2673,34^{* *}$ & 2 & $11084,06^{* *}$ & & $996,77^{*}$ \\
\hline Topcross & 112 & 477,48 & 112 & $505,64 * *$ & 112 & $714,02^{* *}$ & 112 & $609,27 * *$ \\
\hline Erro & 219 & 379,86 & 220 & 236,76 & 220 & 327,37 & 219 & 305,79 \\
\hline C.V. & & 23,80 & & 15,56 & & 12,93 & & 10,15 \\
\hline $\mathbf{R}^{2}$ & & 0,42 & & 0,54 & & 0,59 & & 0,51 \\
\hline \multicolumn{9}{|l|}{ PG } \\
\hline Bloco & 2 & $2690,64^{* *}$ & 2 & $1967,90 * *$ & 2 & $7339,07^{* *}$ & & 970,94* \\
\hline Topcross & 112 & $356,11^{*}$ & 112 & $358,85 * *$ & 112 & $517,67 * *$ & 112 & $375,32 * *$ \\
\hline Erro & 219 & 270,16 & 219 & 159,97 & 220 & 234,78 & 221 & 217,44 \\
\hline C.V. & & 25,66 & & 16,38 & & 13,54 & & 10,82 \\
\hline $\mathbf{R}^{2}$ & & 0,43 & & 0,56 & & 0,58 & & 0,48 \\
\hline
\end{tabular}

**, * significativo pelo teste $\mathrm{F}$ a 1 e $5 \%$ de probabilidade, respectivamente. 
Tabela 3. Análise de variância conjunta para os caracteres teor de proteína (\%), teor de óleo (\%), peso de espigas (PE, g/pl) e peso de grãos (PG, g/pl). Dois testadores e dois locais, Piracicaba, 1999/2000.

\begin{tabular}{|c|c|c|c|c|c|c|c|c|}
\hline \multirow[t]{2}{*}{ F. V. } & \multicolumn{2}{|c|}{ Proteína } & \multicolumn{2}{|c|}{ Óleo } & \multicolumn{2}{|c|}{$\mathrm{PE}$} & \multicolumn{2}{|c|}{$\mathrm{PG}$} \\
\hline & g.l. & QM & g.l. & QM & g.1. & QM & g.1. & QM \\
\hline Bloco $/ \mathrm{L} / \mathrm{T}$ & 8 & $2,0377^{* *}$ & 8 & $0,3059 * *$ & 8 & $4621,50 * *$ & $\overline{8}$ & $3242,14 * *$ \\
\hline Local (L) & 1 & $92,6693 * *$ & 1 & $10,4906 * *$ & 1 & $1421569,22 * *$ & 1 & $965105,76^{* *}$ \\
\hline Testador $(T)$ & 1 & 2,0648 & 1 & $18,8001 * *$ & 1 & $185900,94 * *$ & 1 & $100885,98^{* *}$ \\
\hline Progênie (P) & 119 & 1,1222 & 119 & $0,0957 * *$ & 119 & 689,81 & 119 & 476,27 \\
\hline$L \times T$ & 1 & 1,7171 & 1 & 0,0029 & 1 & $19407,41^{* *}$ & 1 & $8341,66 * *$ \\
\hline$L \times P$ & 119 & 0,5371 & 119 & 0,0270 & 119 & 418,51 & 119 & 288,49 \\
\hline$T \times P$ & 105 & $1,1414 * *$ & 105 & $0,0567 * *$ & 105 & 635,33 & 105 & 455,11 \\
\hline $\mathrm{L} \times \mathrm{T} \times \mathrm{P}$ & 105 & $0,4507 * *$ & 105 & 0,0295 & 105 & $564,82 * *$ & 105 & $390,37 * *$ \\
\hline erro médio & 758 & 0,3120 & 758 & 0,0253 & 878 & 312,37 & 879 & 220,59 \\
\hline $\mathrm{R}^{2}$ & & 0,68 & & 0,76 & & 0,88 & & 0,87 \\
\hline C.V. & & 5,53 & & 3,57 & & 14,34 & & 15,20 \\
\hline
\end{tabular}

**, * significativo pelo teste $\mathrm{F}$ a 1 e $5 \%$ de probabilidade, respectivamente. 
Tabela 4. Análise de variância agrupada por local para os caracteres teor de proteína $(\%)$, teor de óleo (\%), peso de espigas ( $\mathrm{PE}, \mathrm{g} / \mathrm{pl}$ ) e peso de grãos (PG, $\mathrm{g} / \mathrm{pl})$, Piracicaba, 1999/2000.

\begin{tabular}{|c|c|c|c|c|c|c|c|c|}
\hline \multirow[t]{2}{*}{ F. V. } & \multicolumn{2}{|c|}{ Proteína } & \multicolumn{2}{|c|}{ Óleo } & \multicolumn{2}{|c|}{ PE } & \multicolumn{2}{|c|}{ PG } \\
\hline & g.1. & QM & g.1. & QM & g.1. & QM & g.1. & QM \\
\hline \multicolumn{9}{|l|}{ ANHEMBI } \\
\hline Bloco/T & 4 & $2,9866 * *$ & 4 & $0,5796 * *$ & 4 & $3202,59 * *$ & 4 & $2329,27 * *$ \\
\hline Testador (T) & 1 & $3,7176 *$ & 1 & $9,0319 * *$ & 1 & $42539,16 * *$ & 1 & $25485,72 * *$ \\
\hline Progênie (P) & 119 & 0,9384 & 119 & 0,0575 & 119 & 485,60 & 119 & 353,11 \\
\hline$T \times P$ & 105 & $0,7789 * *$ & 105 & $0,0490 * *$ & 105 & $497,72 * *$ & 105 & $360,92 * *$ \\
\hline erro médio & 376 & 0,4141 & 376 & 0,0270 & 439 & 308,15 & 438 & 215,06 \\
\hline $\mathrm{R}^{2}$ & & 0,58 & & 0,72 & & 0,60 & & 0,56 \\
\hline C.V. & & 6,56 & & 3,77 & & 19,42 & & 20,77 \\
\hline \multicolumn{9}{|l|}{ CATERPLLAR } \\
\hline Bloco/T & 4 & $1,0888^{* *}$ & 4 & 0,0321 & 4 & $6040,42 * *$ & 4 & $4155,00 * *$ \\
\hline Testador (T) & 1 & 0,0081 & 1 & $9,7825^{* *}$ & 1 & $162909,48 * *$ & 1 & $84014,06 * *$ \\
\hline Progênie (P) & 119 & 0,7529 & 119 & $0,0666^{* *}$ & 119 & 623,71 & 119 & 413,89 \\
\hline$T \times P$ & 105 & $0,8025^{* *}$ & 105 & $0,0364 * *$ & 105 & $702,73 * *$ & 105 & $484,02 * *$ \\
\hline erro médio & 382 & 0,2115 & 382 & 0,0236 & 439 & 316,60 & 441 & 226,09 \\
\hline $\mathrm{R}^{2}$ & & 0,69 & & 0,71 & & 0,71 & & 0,67 \\
\hline C.V. & & 4,42 & & 3,37 & & 11,40 & & 12,05 \\
\hline
\end{tabular}

**, * significativo pelo teste $\mathrm{F}$ a 1 e $5 \%$ de probabilidade, respectivamente. 
Tabela 5. Análise de variância agrupada por testador para os caracteres teor de proteína (\%), teor de óleo (\%), peso de espigas (PE, g/pl) e peso de grãos (PG, g/pl), Piracicaba, 1999/2000.

\begin{tabular}{lrrrrrrrr}
\hline F. V. & \multicolumn{2}{c}{ Proteína } & \multicolumn{2}{c}{ Óleo } & \multicolumn{2}{c}{ PE } & \multicolumn{2}{c}{ PG } \\
\cline { 2 - 10 } & g.l. & QM & g.l. & QM & g.l. & QM & g.l. & QM \\
\hline BR108 & & & & & & & & \\
Bloco/L & 4 & $2,2689^{* *}$ & 4 & 0,0424 & 4 & $7407,95^{* *}$ & 4 & $5014,86^{* *}$ \\
Local (L) & 1 & $63,0466^{* *}$ & 1 & $5,3039^{* *}$ & 1 & $564085,00^{* *}$ & 1 & $403181,20^{* *}$ \\
Progênie (P) & 112 & $1,0156^{* *}$ & 112 & $0,0889^{* *}$ & 112 & 654,34 & 112 & 467,61 \\
L x P & 112 & $0,4989^{* *}$ & 112 & 0,0284 & 112 & $533,80^{* *}$ & 112 & $403,06^{* *}$ \\
Erro médio & 377 & 0,3437 & 377 & 0,0248 & 439 & 353,56 & 439 & 252,43 \\
& & & & & & & & \\
$\mathrm{R}^{2}$ & & 0,66 & & 0,68 & & 0,82 & & 0,82 \\
C.V. & & 5,83 & & 3,64 & & 16,94 & & 17,92 \\
CML269 & & & & & & & & \\
Bloco/L & 4 & $1,8066^{* *}$ & 4 & $0,5694^{* *}$ & 4 & $1835,06^{* *}$ & 4 & $1469,42^{* *}$ \\
Local (L) & 1 & $35,0834^{* *}$ & 1 & $5,4242^{* *}$ & 1 & $898023,19^{* *}$ & 1 & $584037,40^{* *}$ \\
Progênie (P) & 112 & $1,2744^{* *}$ & 112 & $0,0715^{* *}$ & 112 & $674,08^{*}$ & 112 & $465,81^{* *}$ \\
L x P & 112 & $0,4962^{* *}$ & 112 & 0,0288 & 112 & $442,47^{* *}$ & 112 & $269,43^{* *}$ \\
Erro médio & 381 & 0,2806 & 381 & 0,0258 & 439 & 271,19 & 440 & 188,83 \\
$\mathrm{R}^{2}$ & & & & & & & & \\
C.V. & & 0,70 & & 0,67 & & 0,90 & & 0,89 \\
\hline
\end{tabular}

**, * significativo pelo teste $\mathrm{F}$ a 1 e $5 \%$ de probabilidade, respectivamente. 
Tabela 6. Médias das testemunhas, média, valores mínimo e máximo dos testcrosses para os caracteres teor de proteína (\%), teor de óleo (\%), peso de espigas (PE, $\mathrm{t} / \mathrm{ha}$ ) e peso de grãos (PG, t/ha). Dois testadores e dois locais, Piracicaba, $1999 / 2000$.

\begin{tabular}{|c|c|c|c|c|}
\hline \multirow[t]{2}{*}{ Caráter } & \multicolumn{2}{|r|}{ Anhembi } & \multicolumn{2}{|c|}{ Caterpillar } \\
\hline & BR108 & CML269 & BR108 & CML269 \\
\hline PRUIEINA & & & & \\
\hline BR2121 $\otimes$ & $11,06 \mathrm{a}^{\#}$ & $10,25 \mathrm{a}$ & $10,27 \mathrm{a}$ & $10,24 \mathrm{a}$ \\
\hline BR2121 X & $8,59 \mathrm{~b}$ & $9,14 \mathrm{~b}$ & $9,56 \mathrm{~b}$ & $9,66 \mathrm{~b}$ \\
\hline Master & $8,27 \quad b$ & $8,68 \mathrm{c}$ & $9,14 \mathrm{c}$ & $9,08 \mathrm{c}$ \\
\hline \multicolumn{5}{|l|}{ Testcrosses } \\
\hline Média & 9,72 & 9,89 & 10,39 & 10,39 \\
\hline Mínimo & 8,40 & 8,72 & 9,23 & 8,74 \\
\hline Máximo & 11,51 & 11,36 & 11,42 & 11,82 \\
\hline \multicolumn{5}{|l|}{ ÓLEO } \\
\hline BR2121 $\otimes$ & 5,49 a & 5,24 a & 6,17 a & 6,15 a \\
\hline BR2121 X & $5,02 \mathrm{~b}$ & $5,08 \mathrm{~b}$ & $6,00 \mathrm{~b}$ & $5,83 \mathrm{~b}$ \\
\hline Master & $4,26 \mathrm{c}$ & $4,29 \mathrm{c}$ & $4,71 \quad \mathrm{c}$ & $4,78 \mathrm{c}$ \\
\hline \multicolumn{5}{|l|}{ Testcrosses } \\
\hline Média & 4,22 & 4,48 & 4,41 & 4,68 \\
\hline Mínimo & 3,77 & 4,03 & 3,93 & 4,28 \\
\hline Máximo & 4,56 & 4,86 & 4,71 & 5,10 \\
\hline \multicolumn{5}{|l|}{ PE } \\
\hline BR2121 X & $4,61 \mathrm{~b}$ & 5,24 a & $6,96 \mathrm{~b}$ & $8,56 \mathrm{a}$ \\
\hline Master & 5,25 a & $5,55 a$ & 7,59 a & 8,91 a \\
\hline \multicolumn{5}{|l|}{ Testcrosses } \\
\hline Média & 3,64 & 4,39 & 6,22 & 7,65 \\
\hline Mínimo & 2,64 & 2,88 & 4,73 & 6,28 \\
\hline Máximo & 5,29 & 5,86 & 8,21 & 9,72 \\
\hline \multicolumn{5}{|l|}{ PG } \\
\hline BR2121 X & $3,63 \mathrm{~b}$ & $4,16 \mathrm{~b}$ & $5,59 \mathrm{~b}$ & $6,87 \mathrm{~b}$ \\
\hline Master & 4,46 a & $4,68 \mathrm{a}$ & 6,33 a & 7,36 a \\
\hline \multicolumn{5}{|l|}{ Testcrosses } \\
\hline Média & 2,84 & 3,43 & 5,03 & 6,06 \\
\hline Mínimo & 2,03 & 2,23 & 3,82 & 4,92 \\
\hline Máximo & 4,30 & 4,83 & 6,70 & 7,52 \\
\hline
\end{tabular}


Tabela 7. Número de testcrosses com média superior $(>)$, igual $(=)$ e inferior $(<)$ à da melhor testemunha, pelo teste $\mathrm{t}$ a $5 \%$ de probabilidade, para os teor de proteína, teor de óleo, peso de espigas (PE) e peso de grãos (PG). Dois testadores e dois locais, Piracicaba, 1999/2000.

\begin{tabular}{lrrrrrrrrrrrrr}
\hline Caráter & \multicolumn{4}{c}{ Anhembi } & \multicolumn{1}{c}{ Caterpillar } \\
\cline { 2 - 14 } & \multicolumn{3}{c}{ BR108 } & \multicolumn{4}{c}{ CML269 } & \multicolumn{3}{c}{ BR108 } & \multicolumn{3}{c}{ CML269 } \\
\cline { 2 - 15 } & $>$ & $=$ & $<$ & $>$ & $=$ & $<$ & $>$ & $=$ & $<$ & $>$ & $=$ & $<$ \\
\hline PROTEINA & 0 & 23 & 90 & 2 & 79 & 32 & 16 & 91 & 6 & 20 & 83 & 10 \\
OLEO & 0 & 0 & 113 & 0 & 0 & 113 & 0 & 0 & 113 & 0 & 0 & 113 \\
PE & 0 & 20 & 93 & 0 & 33 & 80 & 0 & 35 & 78 & 0 & 35 & 78 \\
PG & 0 & 12 & 101 & 0 & 18 & 95 & 0 & 30 & 83 & 0 & 16 & 97 \\
\hline
\end{tabular}


Tabela 8. Valores do teste $\mathrm{F}$ para o efeito de testcrosses, variância aditiva interpopulacional, ganho genético esperado em valor absoluto (Gs) e em percentual $(\mathrm{Gs} \%)$ para os teor de proteína $(\%)$, teor de óleo $(\%)$, peso de espigas ( $\mathrm{PE}, \mathrm{g} / \mathrm{pl}$ ) e peso de grãos ( $\mathrm{PG}, \mathrm{g} / \mathrm{pl})$, dois testadores e dois locais. Piracicaba, 1999/2000.

\begin{tabular}{|c|c|c|c|c|}
\hline \multirow[t]{2}{*}{ Caráter } & \multicolumn{2}{|c|}{ Anhembi } & \multicolumn{2}{|c|}{ Caterpillar } \\
\hline & BR108 & CML269 & BR108 & CML269 \\
\hline \multicolumn{5}{|c|}{ PROTEINA } \\
\hline $\mathrm{F}$ & $1,96 b^{\#}$ & $2,29 \mathrm{~b}$ & $2,52 \mathrm{~b}$ & $5,31 \mathrm{a}$ \\
\hline$\sigma_{A 12}^{2}$ & $0,640 \pm 0,186$ & $0,737 \pm 0,183$ & $0,553 \pm 0,127$ & $1,124 \pm 0,185$ \\
\hline Gs & 0,40 & 0,48 & 0,44 & 0,93 \\
\hline Gs $\%$ & 4,07 & 4,86 & 4,28 & 8,97 \\
\hline \multicolumn{5}{|l|}{ ÓLEO } \\
\hline $\mathrm{F}$ & $2,02 \mathrm{ab}$ & $2,13 a b$ & $2,92 \mathrm{a}$ & $1,85 \mathrm{~b}$ \\
\hline$\sigma_{\mathrm{A} 12}^{2}$ & $0,045 \pm 0,013$ & $0,041 \pm 0,011$ & $0,057 \pm 0,012$ & $0,034 \pm 0,011$ \\
\hline Gs & 0,11 & 0,11 & 0,16 & 0,09 \\
\hline Gs $\%$ & 2,56 & 2,38 & 3,56 & 1,83 \\
\hline \multicolumn{5}{|l|}{$\mathrm{PE}$} \\
\hline $\mathrm{F}$ & $1,26 \mathrm{~b}$ & $2,14 \mathrm{a}$ & $2,18 \mathrm{a}$ & $1,99 \mathrm{a}$ \\
\hline$\sigma_{\mathrm{A} 12}^{2}$ & $132,13 \pm 98,48$ & $362,83 \pm 95,28$ & $521,74 \pm 134,27$ & $410,76 \pm 116,04$ \\
\hline Gs & 2,93 & 9,74 & 11,88 & 9,77 \\
\hline Gs \% & 3,58 & 9,85 & 8,49 & 5,67 \\
\hline \multicolumn{5}{|l|}{ PG } \\
\hline $\mathrm{F}$ & $1,32 \mathrm{~b}$ & $2,24 \mathrm{a}$ & $2,20 \mathrm{a}$ & $1,73 \mathrm{ab}$ \\
\hline$\sigma_{\mathrm{A} 12}^{2}$ & $116,33 \pm 72,63$ & $269,19 \pm 67,52$ & $381,73 \pm 97,25$ & $212,40 \pm 72,34$ \\
\hline Gs & 3,05 & 8,74 & 10,25 & 6,08 \\
\hline Gs \% & 4,76 & 11,32 & 9,06 & 4,46 \\
\hline
\end{tabular}

"Valores de F seguidos de mesma letra na linha não diferem pelo teste de Schumann-Bradley a 5\% de probabilidade 
Tabela 9. Correlações fenotípicas entre os caracteres percentual de proteína, percentual de óleo, peso de espigas (PE) e peso de grãos (PG) nos locais Anhembi (acima da diagonal) e Caterpillar (abaixo da diagonal). Piracicaba, 1999/2000.

\begin{tabular}{|c|c|c|c|c|}
\hline & PROTEINA & OLEO & $\mathrm{PE}$ & PG \\
\hline \multicolumn{5}{|l|}{ PROTEÍNA } \\
\hline BR108 & & $0,2070^{*}$ & $-0,0011$ & $-0,0040$ \\
\hline CML269 & & $0,4060^{*}$ & 0,0301 & $-0,0508$ \\
\hline \multicolumn{5}{|l|}{ ÓLEO } \\
\hline BR108 & $0,2305 *$ & & $0,1870 *$ & $0,2038^{*}$ \\
\hline CML269 & $0,3461^{*}$ & & 0,0447 & $-0,0165$ \\
\hline \multicolumn{5}{|l|}{$\mathrm{PE}$} \\
\hline BR108 & 0,0073 & $0,2547^{*}$ & & $0,9783 *$ \\
\hline CML269 & 0,1043 & 0,0964 & & $0,9728^{*}$ \\
\hline \multicolumn{5}{|l|}{ PG } \\
\hline BR108 & $-0,0259$ & $0,2300 *$ & 0,9793* & \\
\hline CML269 & 0,0162 & 0,0781 & $0,9320^{*}$ & \\
\hline
\end{tabular}

* significativo a $5 \%$ de probabilidade. 


\section{CONCLUSÕES GERAIS}

Com base nos resultados do presente trabalho, foi possível concluir que:

a) tanto as dez populações estudadas quanto as progênies dentro da população ESA23B divergem para a maioria dos caracteres, indicando a possibilidade de seleção de genótipos com melhor qualidade nutricional;

b) a interação tratamentos $\mathrm{x}$ ambientes teve pouca influência no experimento envolvendo populações, permitindo a seleção para a média dos ambientes, mas foi importante no experimento de topcross, o que indica que a melhor forma de seleção deve ser analisada caso a caso;

c) a composição de aminoácidos varia de acordo com o teor de proteína;

d) as associação entre qualidade nutricional e rendimento foram fracas e, em geral, não significativas; portanto, não deve haver dificuldade na obtenção de cultivares de milho que reunam ambos os caracteres. 


\section{REFERÊNCIAS BIBLIOGRÁFICAS}

ALEXANDER, D.E. High oil corn-breeders aim for improved quality. Crop and Soil Magazine, v.38, n.1, p.11-12, 1986.

ALEXANDER, D.E. Oil content versus grain yield in corn. Maydica, v.44, n.1, p.111-112, 1999.

ALEXANDER, D.E.; LAMBERT, R.J. Relationship of kernel oil content to yield in maize. Crop Science, v.8, n.3, p.273-4, 1968.

ALEXANDER, D.E.; LAMBERT, R.J.; DUDLEY, J.W. Breeding problems and potentials of modified protein maize. In: NEW APPROACHES TO BREEDING FOR IMPROVED PLANT PROTEIN. Proceedings. Vienna: IEAA, 1969. p.5565.

ALLISON, J.C.S.; CURNOW, R.W. On the choice of tester parent for the breeding of synthetic varieties of maize (Zea mays L.). Crop Science, v.6, n.3, p.541-4, 1966.

ASSOCIAÇÃO NACIONAL DOS PRODUTORES DE RAÇÃO. Estatísticas. $\mathrm{http} / /$ negociospecuarios.terra.com.br/Html/cotacao (24/10/01).

ASSOCIATION OF OFFICIAL ANALYTICAL CHEMISTS Official methods of analysis of AOAC International. $16 \mathrm{ed}$. Washington, 1995. 1141p.

BARIONI Jr., W.; LIMA, G.J.M.M.; KLEIN, C.H. Classificação de milho para produção de rações para suínos. In: CONGRESO MERCOSUR DE PRODUCCION PORCINA, 2000, Buenos Aires. Memoria. Buenos Aires, 2000. p.NA-14.

BATISTA, L.A.R. Seleção para tamanho do embrião relacionada com o teor de óleo do grão de milho. Piracicaba, 1980. 72p. Dissertação (Mestrado) - Escola Superior de Agricultura "Luiz de Queiroz", Universidade de São Paulo. 
BATISTA, L.A.R.; TOSELLO, G.A. Influência da fonte polinizadora sobre o conteúdo de óleo em grãos de milho. Pesquisa Agropecuária Brasileira, v.17, p.1757-62, 1982.

BEADLE, J.B.; JUST, D.E.; MORGAN, R.E.; REINERS, R.A. Composition of corn oil. Journal of American Oil Chemistry Society, v.42, n.2, p.90, 1965.

BENTON, D.A; HARPER, A.E.; ELVEHJEM, C.A. Effect of isoleucine suplementation on the growth of rats fed zein or corn diets. Archives of Biochemisty and Biophysics, v.57, n.1, p.13-19, 1955.

BENTON, D.A; HARPER, A.E.; SPIVEY,H.E.; ELVEHJEM, C.A. Leucine, isoleucine and valine relationships in the rat. Archives of Biochemisty and Biophysics, v.60, n.2, p.147-155, 1956.

BERKE, T.G.; ROCHEFORD, T.R. Quantitative trait loci for flowering, plant and ear height, and kernel traits in maize. Crop Science, v.35, n.6, p.1542-1549, 1995.

BIANCO, S. Avaliação do potencial genético de populações de milho (Zea mays, L.) braquítico para o teor de óleo na semente. Piracicaba, 1984. 98p. Dissertação (Mestrado) - Escola Superior de Agricultura "Luiz de Queiroz", Universidade de São Paulo.

BRESSANI, R.; ELÍAS, L.G.; SCRIMSHAW, N.S.; GUZMÁN, M.A . Nutritive value of central american corns. VI. Varietal and environment influence of the nitrogen, essential amino acid, and fat content of ten varieties. Cereal Chemistry, v.39, n.1, p.59-67, 1962.

BURSTIN, J.; CHARCOSSET, A. Relationship between phenotypic and marker distances: theoretical and experimental investigations. Heredity, v.79, n.5, p.477483, 1996.

CASTÈLLANOS, J.S.; HALLAUER, A.R.; CORDOVA, H.S. Relative performance of testers to identify elite lines of corn (Zea mays L.). Maydica, v.43, n.3, p.217226, 1998.

CHARCOSSET, A.; LEFORT-BUSON, M.; GALLAIS, A. Relationship between heterosis and heterozygosity at marker loci: a theoretical computation. Theoretical and Applied Genetics, v.81, n.5, p.571-575, 1991.

CHARCOSSET, A.; LEFORT-BUSON, M.; GALLAIS, A. Use of top-cross designs for predicting performance of maize single cross hybrids. Maydica, v.35, n.1, p.23-7, 1990. 
CHOE, B.; ZUBER, M.S.; KRAUSE, G.F et al. Inheritance of high lysine in maize. Crop Science, v.16, n.1, p.34-38, 1976.

CORCUERA, V.R.; NARANJO, C.A. Inheritance of protein content in the endosperm. Maize Genetics Cooperation Newsletter, v.69, p.125, 1995.

CRUZ, C.D. Aplicação de algumas técnicas multivariadas no melhoramento de plantas. Piracicaba, 1990. 188p. Tese (Doutorado) - Escola Superior de Agricultura "Luiz de Queiroz", Universidade de São Paulo.

CRUZ, C.D.; REGAZZI, A.J. Modelos biométricos aplicados ao melhoramento genético. Viçosa: UFV, 1994. 390p.

DAVIS, R.L. Report of the plant breeder. Reports of Puerto Rico Agricultural Experimental Station, p.14-15, 1927.

DORSEY-REDDING, C.D.; HURBURGH Jr., C.R.; JOHNSON, L.A.; FOX, S.R. Relationships among maize quality factors. Cereal Chemistry, v.68, n.6, p.602605, 1991.

DUDLEY, J.W. Seventy-six generations of selection for oil and protein percentage in maize. In: INTERNATIONAL CONFERENCE ON QUANTITATIVE GENETICS, Ames, 1976. Proceedings. Ames: Iowa State University Press, 1977. p.459-473.

DUDLEY . J.W.; LAMBERT, R.J. Ninety generations of selection for oil and protein in maize. Maydica, v.37, n.1, p.81-87, 1992.

EAST, E.M.; JONES, D.F. Genetic studies on the protein content of maize. Genetics, v.5, n.4, p.543-610, 1920.

EMPRESA BRASILEIRA DE PESQUISA AGROPECUÁRIA. Tabela de composição química e valores energéticos de alimentos para suínos e aves. Concórdia, 1991. 97p. (Série Documentos, 19)

FAO. El maiz en la nutrición humana. Roma, 1993. 110p. (Estudio de alimentacion y nutrición, 35/1)

FITCH, B. Corn oil. Journal of American Oil Chemistry Society, v.62, n.12, p.1524-27, 1985.

FAO/WHO EXPERT CONSULTATION COMITTE. Protein Quality Evaluation. Rome, 1991. (FAO/WHO Nutrition Meetings, Report Series 51) 
FAO/WHO EXPERT CONSULTATION COMMITTEE. Energy and Protein Requirements. Geneva, 1985. (FAO/WHO Nutrition Meetings, Report Series 724)

FREY, K.J. The interrelationships of proteins and amino acids in corn. Cereal Chemistry, v.28, n.3, p.123-132, 1951.

GARCIA, A.A.F. Seleção recorrente fenotípica para melhoramento da qualidade protéica em duas populações de milho (Zea mays L.) não opaco. Piracicaba, 1993. 125p. Dissertação (Mestrado) - Escola Superior de Agricultura "Luiz de Queiroz", Universidade de São Paulo.

GARWOOD, D.L.; WEBER, E.J.; LAMBERT, R.J.; ALEXANDER, D.E. Effect of different cytoplasms on oil, fatty acids, plant height, and ear height in maize (Zea mays L.). Crop Science, v.10, n.1, p.39-41, 1970.

GENTER, C.F.; EHEART, J.F.; LINKOUS, W.N. Effects of location, hybrid, fertilizer, and rate of planting on the oil and protein contents of corn grain. Agronomy Journal, v.48, n.1, p.63-67, 1956.

GENTINETTA, E.; MAGGIORE, T.; SALAMINI, F. et al. Protein studies in 46 opaque-2 strains with modified endosperm texture. Maydica, v.20, n.3, p.145$164,1975$.

GOLDMAN, I.L.; ROCHEFORD, T.R.; DUDLEY, J.W. Quantitative trait loci influencing protein and starch concentration in the Illinois Long Term Selection maize strains. Theoretical and Applied Genetics, v.87, n.1-2, p.217-224, 1993.

HALLAUER, A.R. Relation of gene action and type of tester in maize breeding procedures. In: ANNUAL CORN AND SORGHUM RESEARCH CONFERENCE, 30, Proceedings. Washington: American Seed Trade Association, 1975. p.150-165.

HALLAUER, A.R.; MIRANDA FILHO, J.B. Quantitative genetics in maize breeding. Ames: Iowa State University Press, 1981. 468p.

HAN, Y.; PARSONS, C.M.; ALEXANDER, D.E. Nutritive value of high-oil corn for poultry. Poultry Science, v.66, n.1, p.103, 1987.

HOHLS, T.; SHANAHAN, P.E.; PETER CLARKE, G. et al. Genetic control of kernel modification found in South African quality protein maize inbred lines. Euphytica, v.87, n.2, p.103-109, 1996. 
HOLTHAUS, J.F.; LAMKEY, K.R. Response to selection and changes in genetic parameters for 13 plant and ear traits in two maize recurrent selection programs. Maydica, v.40, n.4, p.357-70, 1995.

HORNER, E.S.; LUNDY, H.W.; LUTRICK, M.C.; CHAPMAN, W.H. Comparison of three methods of recurrent selection in maize. Crop Science, v.13, n.4, p.485489, 1973.

HYMOWITZ, T.; DUDLEY, J.W.; COLLINS, F.I. et al. Estimations of protein and oil concentration in corn, soybean, and oat seed by near-infrared light reflectance. Crop Science, v.14, n.5, p.713-715, 1974.

JENKINS, M.T.; BRUNSON, A.M. Methods of testing inbred lines of maize in crossbred combinations. Journal of the American Society of Agronomy, v.24, n.7, p.523-30, 1932.

KIBITE, S.; EVANS, L.E. Causes of negative correlations between grain yield and grain protein concentration in common wheat. Euphytica, v.33, n.3, p.801-10, 1984.

KODRZYCKY, R.; BOSTON, R.; LARKINS, B.A. The opaque-2 mutation of maize differentially reduces zein gene transcription. Plant Cell, v.1, n.2, p.105-114, 1989.

LAMBERT, R.J; ALEXANDER.D,E; DUDLEY, J.W. Relative performance of normal and modified protein (opaque-2) maize hybrids. Crop Science, v.9, n.2, p.242-243, 1969.

LAMBERT, R.J.; ALEXANDER.D,E.; HAN, Z.J. A high oil pollinator enhancement of kernel oil and effects on grain yields of maize hybrids. Agronomy Journal, v.90, n.2, p.211-215, 1998.

LAMBERT, R.J.; ALEXANDER.D,E.; MOLLRING, E.L.; WIGGENS, B. Selection for increased oil concentration in maize kernels and associated changes in several kernel traits. Maydica, v.42, n.1, p.39-43, 1997.

LAMBERT, R.J.; ALEXANDER.D,E.; ROGERS, R.C. Effect of kernel position on oil content in corn (Zea mays L.). Crop Science, v.7, n.1, p.143-4, 1967.

LANDRY, J.; MOUREAUX, J. Hétérogéneité des glutélines du grain de mais: extration sélective et composition en acidez aminés des trios fractions isoléés, Bulletin de la Societé de Chimie Biologique, v.52, n.9, p.1021-1026, 1970.

LETCHWORTH, M.B.; LAMBERT, R.J. Pollen parent effect on oil, protein, and starch concentration in maize kernels. Crop Science, v.38, n.2, p.363-367, 1998. 
LIMA, G.J.M.M.; SINGER, J.M.; GUIDONI, A.L.; ANDRADE, D.; BALLAVER, C. Classificação do milho, quanto à composição em alguns nutrientes, através do emprego de análise de conglomerados. In: CONGRESSO NACIONAL DE MILHO E SORGO, 23., Uberlândia, 2000. Anais. Uberlândia: ABMS, 2000. p.318.

LIMA, G.J.M.M.; NONES, K.; KLEIN, C.H.; BELLAVER, C.; ZANOTTO, D.L.; BRUM, P.A.R. de; PEREIRA, L.R. Composição química de híbridos comerciais de milho testados na safra 1999/2000. In: REUNIÃO TÉCNICA ANUAL DO SORGO, 28., REUNIÃO TÉCNICA ANUAL DO MILHO, 45., Pelotas, 2000. Resumos. Pelotas: EMBRAPA/CPACT, 2000. p.83-192.

LOPES, A. M.; MORO, G.L.; LARKINS, B. Genetic mapping of opaque-2 modifier genes. Maize Genetics Cooperation Newsletter, v.69, p.125, 1995.

MERTZ, E.T.; BATES, L.S.; NELSON, O.E. Mutant genes that changes protein composition and increases lysine content of maize endosperm. Science, v.145, n.7, p.279-280, 1964.

MICU, V.E.; PARTAS, V.E.; ROTARI, A.I. The revealing and selection of high protein sources of maize. Maize Genetics Cooperation Newsletter, v.69, p.115, 1995.

MILLER, P.A.; BRIMHALL, B. Factors influencing the oil and protein content of corn grain. Agronomy Journal, v.43, n.3, p.305-311, 1951.

MILLER, R.C.; AURAND, L.W.; FLACH, W.R. Amino acids in high and low protein corn. Science, v.112, n.1, p.57-58, 1950.

MIRANDA FILHO, J.B.; GORGULHO, E.P. Cruzamentos com testadores e dialelos. In: NASS, L.L.; VALOIS, A.C.C.; MELO, I.S. de; VALADARES-INGLIS, M.C. Recursos genéticos e melhoramento: plantas. Rondonópolis: Fundação MT, 2001. Cap.21:649-71.

MIRANDA FILHO, J.B.; VENCOVSKY, R. Variance among testcrosses. Piracicaba: USP/ESALQ, Departamento de Genética, 2001. 11p. (Publicação Didática)

MISEVIC, D.; ALEXANDER, D.E. Twenty-four cicles of phenotypic recurrent selection for percent oil in maize. I. Per se and test-cross performance. Crop Science, v.29, n.2, p.320-324, 1989. 
MORO, G.; HABBEN, J.E.; HAMAKER, B.R.; LARKINS, B.A. Characterization of the variability in lysine content for normal and opaque-2 maize endosperm. Crop Science, v.36, n.6, p.1651-1659, 1996.

NASPOLINI FILHO, V.; GAMA, E.E.G.; VIANNA, R.T. et al. General and specific combining ability for yield in a diallel cross among 18 maize populations (Zea mays L.). Revista Brasileira de Genética, v.4, n. 3, p.571-577, 1981.

NASS, L. L.; MIRANDA FILHO, J. B. Avaliação, identificação de padrões heteróticos e síntese de populações no germoplasma de milho. Brasília: EMBRAPA, CENARGEN, 1997, p.1-3. (Pesquisa em Andamento, 7)

NELSON, O.E. The modification by mutation of protein quality in maize. In: NEW APPROACHES TO BREEDING FOR IMPROVED PLANT PROTEIN. Proceedings. Vienna: IAEA, 1969. p.41-54.

NELSON, O.E; MERTZ, E.T; BATES, L.S. Second mutant gene affecting the amino acid pattern of maize endosperm proteins. Science, v.150, n.10, p.1469-1470, 1965.

NORDSTRON, J.W.; BEHRENDS, B.R.; MEADE, R.J.; THOMPSON, E.H. Effects of feeding high oil corns to grow-finishing swine. Journal of American Science, v.35, n.2, p.357, 1972.

OIKEH, S.O.; KLING, J.G.; OKORUWA, A.E. Nitrogen fertilizer management effects on maize grain quality in the West African moist savanna. Crop Science, v.38, n.4, p.1056-1061, 1998.

PACHECO, C.A.P.; GUIMARÃES, P.E. de O.; PARENTONI, S.N.; LOPES, M.A.; SANTOS, M.X. dos; GAMA, E.E.G.; VASCONCELOS, M.J.V.; CORREA, L.A.; MEIRELLES, W.F. O desenvolvimento de milho de alta qualidade nutricional no Brasil. In: REUNIÓN LATINOAMERICANA DE MAIZ, 18., Uberlândia, 1999. p.13-25.

PACKER, D. Variabilidade e endogamia em quatro populações de milho (Zea mays L.). Piracicaba, 1998. 102p. Tese (Doutorado) - Escola Superior de Agricultura "Luiz de Queiroz", Universidade de São Paulo.

PAEZ, A.V.; HELM, J.L.; ZUBER, M.S. Lysine content of opaque-2 maize kernels having different phenotypes. Crop Science, v.9, n.2, p.251-252, 1969.

PAULIS, J.W.; WALL, J.S.; SANDERSON, J. Origin of high methionine content in sugary-1 corn endosperm. Cereal Chemistry, v.55, n.5, p.705-712, 1978. 
PRASAD, S.K.; SINGH, T.P. Heterosis in relation to genetic divergence in maize (Zea mays L.). Euphytica, v.35, n.3, p.919-24, 1986.

ROHLF, F.J.; KISHPAUGS, J.; KIRK, D. NTSYS - Numerical Taxonomy System of Multivariate Statistical Programs. New York: Tech Rep. State University, 1971.

SANTOS, M.X.; PACHECO, C.A.P.; GUIMARÃES, P.E.O. et al. Diallel among twenty eigh varieties of maize. Revista Brasileira de Genética, v.17, n.3, p.277$282,1994$.

SCHUMANN, D.E.W.; BRADLEY, R.A. The comparison of the sensitivities of similar experiments: model $I I$ of the analysis of variance. Biometrics, v.15, n.4, p.405-416, 1959.

SÉNE, M.; THÉVENOT, C.; HOFFMANN, D.; BÉNÉTRIX, F.; CAUSSE, M.; PRIOUL, J.-L. QTLs for grain dry milling properties, composition and vitreousness in maize recombinant inbred lines. Theoretical and Applied Genetics, v.102, n.4, p.591-599, 2001.

SHENK, J.S.; LANDA, I.; HOOVER, M.R. et al. Description and evaluation of a near infrared reflectance spectro-computer for forage and grain analysis. Crop Science, v.21, n.3, p.355-358, 1981.

SHENK, J.S.; WESTERHAUS, M.O. Population definition, sample selection, and calibration procedures for near infrared reflectance spectroscopy. Crop Science, v.31, n.2, p.469-474, 1991.

SILVA, R. M. Valor genético e potencial heterótico de populações de milho (Zea mays L.). Piracicaba, 2001. 121p. Tese (Doutorado) - Escola Superior de Agricultura “Luiz de Queiroz”, Universidade de São Paulo.

SILVA, S.O. Estimativas de parâmetros genéticos em populações de milho braquítico, pelo delineamento I e suas implicações no melhoramento do teor de óleo do grão. Piracicaba, 1990. 136p. Tese (Doutorado) - Escola Superior de Agricultura "Luiz de Queiroz", Universidade de São Paulo.

SINGH, D. The relative importance of characters affeting genetic divergence. The Indian Journal of Genetics and Plant Breeding, v.41, n.2, p.237-245, 1981.

SONG, T.M.; KONG, F.; LI, C.J.; SONG, G.H. Eleven cicles of single kernel phenotypic recurrent selection for percent oil in Zhongzong no. 2 maize synthetic. Journal of Genetics and Breeding, v.53, n.1, p.31-35, 1999. 
SPRAGUE, G.F.; BRIMHALL, B. Relative effectiveness of two systems of selection for oil content of the corn kernel. Agronomy Journal, v.42, n.2, p.83, 1950.

SREERAMULU, C.; BAUMAN, L.F. Yield components and protein quality for opaque-2 and normal diallels of maize. Crop Science, v.10, n.3, p.262-265, 1970.

STEEL, R.G.D.; TORRIE, J.H. Priciples and procedures of statistics: a biometrical approach. 2 ed. New York: McGraw-Hill, 1980. 633p.

TATIS, H.A. Seleção para alto teor de óleo na semente de milho e seus efeitos sobre caracteres agronômicos. Piracicaba, 1990. 118p. Tese (Doutorado) - Escola Superior de Agricultura "Luiz de Queiroz", Universidade de São Paulo.

TELLO, F.; ALVAREZ-TOSTADO, M.A.; ALVARADO, G. A study on the improvement of the essential amino acid balance of corn protein. I. Correlation between racial and varietal characteristics and lysine levels of corn. Cereal Chemistry, v.42, n.7, p.368-364, 1965.

TOSELLO, G.A.; GERALDI, I.O. Estimativas de parâmetros genéticos e fenotípicos para caracteres da planta e da qualidade do grão na população de milho ESALQVD opaco. Relatório Científico do Departamento de Genética, v.14, p.183-90, 1980.

U. S. GRAINS COUNCIL. 1998-1999 Value-Enhanced Corn Quality Report: building global markets for America's grains. Washington, 1999. 123p.

VASAL, S.K. High quality protein corn. In: HALLAUER, A .R. Specialty corns. Florida: CRC Pres, 1994.

VENCOVSKY, R.; BARRIGA, P. Genética biométrica no fitomelhoramento. Ribeirão Preto: Sociedade Brasileira de Genética, 1992. 496 p.

VYN, T.J.; TOLLENAAR, M. Changes in chemical and physical quality parameters of maize grain during three decades of yield improvement. Field Crops Research, v.59, n.2, p.135-140, 1998.

WALLACE, J.C.; LOPES, M.A.; PAIVA, E. et al. New methods for extraction and quantitation of zeins reveal a high content of $\gamma$-zein in modified opaque-2 maize. Plant Phisiology, v.92, n.3, p.191-196, 1990.

WOODWORTH, C.M.; LENG, E.R.; JUGENHEIMER, R.N. Fifty generations of selection for protein and oil in corn. Agronomy Journal, v.44, n.1, p.60-65, 1952. 
WORKMAN, J.J. Jr. NIR spectroscopy calibration basics. In: BURNS, D.A.; CIURCZAK, E.W. Handbook of near-infrared analysis. New York: LC, 1992. 681p. Cap.10 (Practical spectroscopy, 13).

ZANOTTO, M.D. Variabilidade genética e endogamia em duas populações de milho (Zea mays L.) contrastantes para teor de óleo. Piracicaba, 1986. 62p. Dissertação (Mestrado) - Escola Superior de Agricultura "Luiz de Queiroz", Universidade de São Paulo.

ZARKADAS,C.G.; YU, Z.; HAMILTON, R.I.; PATTISON, P.L.; ROSE, N.G.W. Comparison between the protein quality of northern adapted cultivars of common maize and quality protein maize. Journal of Agricultural Food Chemistry, v.43, n.1, p.84-93, 1995.

ZIMBACK, L. Estimação de parâmetros genéticos e fenotípicos em uma variedade de milho dentado braquítico opaco (Zea mays L.). Piracicaba, 1985. 169p. Dissertação (Mestrado) - Escola Superior de Agricultura "Luiz de Queiroz", Universidade de São Paulo.

ZUBER, M.S. Protein quality improvement in maize. In: ANNUAL CORN AND SORGUM RESEARCH CONFERENCE, 30. Proceedings. Washington: American Seed Trade Association, 1975. p.166-184. 
APÊNDICES 
Tabela A. Médias dos testcrosses para o caráter percentual de proteína (\%), dois testadores e dois locais. Piracicaba, 1999/2000.

\begin{tabular}{|c|c|c|c|c|c|c|c|c|}
\hline \multirow[t]{2}{*}{ Progênies } & \multicolumn{4}{|c|}{ Anhembi } & \multicolumn{4}{|c|}{ Caterpillar } \\
\hline & \multicolumn{2}{|c|}{ BR108 } & \multicolumn{2}{|c|}{ CML269 } & \multicolumn{2}{|c|}{ BR108 } & \multicolumn{2}{|c|}{ CML269 } \\
\hline 1 & 9,72 & $a^{*}$ & 11,13 & $\overline{\mathrm{A}}$ & 10,78 & $\bar{a}$ & 10,74 & b \\
\hline 2 & 10,12 & $\mathbf{a}$ & 10,73 & A & 10,86 & a & 10,68 & b \\
\hline 3 & 8,92 & $b^{*}$ & 9,38 & B & 9,49 & $b^{*}$ & 10,10 & c \\
\hline 4 & 9,18 & b* & 9,81 & B & 10,96 & a & 9,70 & d \\
\hline 5 & 10,17 & a & 8,89 & $b^{*}$ & 10,42 & a & 8,74 & $d^{*}$ \\
\hline 6 & 9,66 & $a^{*}$ & 9,75 & b & 9,64 & b & 9,88 & c \\
\hline 7 & 10,68 & $\mathbf{a}$ & 9,92 & b & 10,66 & a & 10,03 & c \\
\hline 8 & 11,51 & $\mathbf{a}$ & 8,82 & $b^{*}$ & 10,94 & $a^{*}$ & 10,79 & b \\
\hline 9 & 9,77 & $a^{*}$ & 10,01 & a & 10,73 & a & 10,46 & b \\
\hline 10 & 9,52 & b * & 9,48 & b & 9,80 & b & 10,26 & c \\
\hline 11 & - & & 9,96 & a & - & & 9,76 & d \\
\hline 12 & 9,46 & $b^{*}$ & - & & 9,64 & $b^{*}$ & $=$ & \\
\hline 13 & 8,53 & $b^{*}$ & 9,83 & b & 9,98 & b & 10,57 & b \\
\hline 14 & 8,93 & $b^{*}$ & 9,40 & $b^{*}$ & 10,51 & a & 9,92 & c \\
\hline 15 & 10,04 & $a^{*}$ & 9,44 & $b^{*}$ & 10,19 & b & 10,15 & c \\
\hline 16 & 9,40 & $b^{*}$ & 9,41 & $b^{*}$ & 9,74 & b & 9,89 & c \\
\hline 17 & 9,29 & $b^{*}$ & 10,14 & a & 10,86 & a & 10,21 & c \\
\hline 18 & 9,57 & b* & 10,58 & a & 9,75 & b & 10,39 & b \\
\hline 19 & 9,58 & b* & 9,31 & $b^{*}$ & 10,91 & $a^{*}$ & 10,41 & b \\
\hline 20 & 9,10 & $b^{*}$ & 9,75 & b & 10,21 & b & 10,76 & b \\
\hline 21 & 9,75 & $a^{*}$ & 10,04 & a & 10,20 & b & 10,29 & c \\
\hline 22 & - & & 9,35 & $b^{*}$ & - & & 9,48 & $d^{*}$ \\
\hline 23 & 9,87 & $a *$ & 10,38 & a & 10,30 & b & 10,95 & $a^{*}$ \\
\hline 24 & 8,96 & $b^{*}$ & 10,49 & a & 9,71 & b & 10,71 & b \\
\hline 25 & 10,26 & a & 9,77 & b & 11,23 & $a^{*}$ & 9,79 & c \\
\hline 26 & 9,64 & $a *$ & 10,34 & a & 10,49 & $\mathbf{a}$ & 10,96 & $\mathbf{a}$ \\
\hline 27 & 9,82 & $a *$ & 10,70 & a & 10,96 & $a^{*}$ & 10,62 & b \\
\hline 28 & 10,44 & a & 10,75 & a & 10,50 & $\mathbf{a}$ & 11,08 & $\mathbf{a}$ \\
\hline 29 & 10,29 & a & 9,35 & b* & 9,73 & b & 10,28 & c \\
\hline 30 & 10,38 & a & 10,19 & a & 10,63 & $\mathbf{a}$ & 10,92 & $b^{*}$ \\
\hline 31 & 10,12 & a & 10,42 & a & 10,31 & b & 10,03 & c \\
\hline 32 & 10,13 & $a^{*}$ & 10,57 & a & 11,35 & $a^{*}$ & 10,23 & c \\
\hline 33 & 9,99 & $a *$ & 9,93 & b & 10,30 & b & 10,41 & b \\
\hline 34 & 9,20 & $b^{*}$ & 9,23 & b* & 10,81 & $\mathbf{a}$ & 10,52 & b \\
\hline 35 & 9,61 & $b^{*}$ & 9,96 & a & 10,86 & $\mathbf{a}$ & 10,76 & b \\
\hline 36 & 8,56 & $b^{*}$ & 10,30 & a & 10,05 & b & 11,25 & $a^{*}$ \\
\hline 37 & 9,55 & $b^{*}$ & 9,31 & b * & 10,58 & $\mathbf{a}$ & 11,07 & $a^{*}$ \\
\hline 38 & 9,01 & $b^{*}$ & 9,44 & $b^{*}$ & 10,26 & b & 10,36 & b \\
\hline 39 & 11,09 & a & - & & 11,10 & $a^{*}$ & - & \\
\hline 40 & 9,74 & $a^{*}$ & 10,07 & a & 10,11 & b & 11,11 & $a^{*}$ \\
\hline 41 & 9,32 & $b^{*}$ & 9,78 & B & 11,04 & $a^{*}$ & 9,79 & c \\
\hline 42 & 8,62 & $b^{*}$ & 9,66 & B & 9,43 & b & 10,53 & b \\
\hline 43 & 9,71 & $a^{*}$ & 9,36 & b * & 9,83 & b & 9,65 & d \\
\hline 44 & 10,17 & a & 8,93 & $b^{*}$ & 10,35 & b & 10,23 & c \\
\hline 45 & 10,31 & a & 10,13 & A & 11,12 & $a^{*}$ & 10,55 & b \\
\hline 46 & 9,92 & $a^{*}$ & 9,89 & B & 9,76 & b & 9,95 & c \\
\hline 47 & 9,67 & $a^{*}$ & 10,48 & a & 10,23 & b & 10,64 & b \\
\hline
\end{tabular}


Tabela A. Médias dos testcrosses para o caráter percentual de proteína (\%), dois testadores e dois locais. Piracicaba, 1999/2000.

\begin{tabular}{|c|c|c|c|c|c|c|c|c|}
\hline \multirow[t]{2}{*}{ Progênies } & \multicolumn{4}{|c|}{ Anhembi } & \multicolumn{4}{|c|}{ Caterpillar } \\
\hline & BR1 & & CML & 269 & BR10 & & $\mathrm{CML}$ & 269 \\
\hline 48 & 10,11 & $a^{*}$ & - & & $10,47 \mathrm{a}$ & & - & \\
\hline 49 & 8,85 & $b^{*}$ & 9,38 & b & $10,01 \quad b$ & b & 10,24 & c \\
\hline 50 & 10,08 & $\mathrm{a} *$ & 9,73 & b & $11,01 \mathrm{a}$ & $a *$ & 10,25 & c \\
\hline 51 & - & & 9,31 & b* & - & & 10,32 & c \\
\hline 52 & 9,55 & b* & 9,35 & b & $9,83 \mathrm{~b}$ & & 10,49 & b \\
\hline 53 & 9,80 & $a^{*}$ & 9,45 & b* & $10,36 \mathrm{~b}$ & b & 10,43 & b \\
\hline 54 & 8,93 & b * & 9,51 & b & 10,89 a & & 10,04 & c \\
\hline 55 & 9,11 & $b^{*}$ & - & & 10,73 a & & - & \\
\hline 56 & 9,30 & b* & 9,03 & $b^{*}$ & $10,79 \mathrm{a}$ & & 9,71 & d \\
\hline 57 & 9,98 & $a^{*}$ & 10,38 & $\mathbf{a}$ & $10,68 \mathrm{a}$ & $\mathbf{a}$ & 10,40 & b \\
\hline 58 & 11,36 & $\mathbf{a}$ & 10,27 & a & $10,14 \quad b$ & b & 10,03 & c \\
\hline 59 & 9,70 & $a^{*}$ & 10,31 & $\mathbf{a}$ & 10,76 a & $\mathbf{a}$ & 9,44 & $d^{*}$ \\
\hline 60 & 9,77 & $a^{*}$ & 8,73 & b * & $10,06 \mathrm{~b}$ & b & 10,45 & b \\
\hline 61 & 9,09 & b * & - & & $9,63 \mathrm{~b}$ & b* & - & \\
\hline 62 & 8,64 & b * & 10,28 & a & 9,79 b & b & 10,24 & c \\
\hline 63 & 10,27 & a & 9,23 & b* & 10,49 a & $\mathbf{a}$ & 9,15 & $d^{*}$ \\
\hline 64 & 8,86 & b* & 9,99 & a & $10,51 \quad \mathrm{a}$ & $\mathbf{a}$ & 10,12 & c \\
\hline 65 & 9,64 & $a^{*}$ & 9,87 & b & $11,43 \quad \mathrm{a}$ & $\mathrm{a} *$ & 9,72 & d \\
\hline 66 & 9,43 & b* & 10,37 & a & 10,82 a & a & 10,21 & c \\
\hline 67 & 9,65 & $a^{*}$ & 9,08 & $b^{*}$ & $10,27 \quad b$ & b & 10,81 & b* \\
\hline 68 & 9,43 & b* & 10,92 & $\mathbf{a}$ & $9,87 \mathrm{~b}$ & b & 10,46 & \\
\hline 69 & 9,88 & $a^{*}$ & 9,39 & b & $10,68 \mathrm{a}$ & $\mathbf{a}$ & 10,86 & b * \\
\hline 70 & 8,83 & b* & 9,87 & b & $10,01 \quad b$ & b & 11,82 & $a^{*}$ \\
\hline 71 & 10,08 & $a^{*}$ & 10,58 & a & $10,71 \quad a$ & $\mathbf{a}$ & 11,47 & $a^{*}$ \\
\hline 72 & 8,89 & $b^{*}$ & 8,85 & b* & $9,63 \mathrm{~b}$ & b* & 9,37 & $d^{*}$ \\
\hline 73 & 9,48 & b* & 10,08 & $\mathbf{a}$ & $9,23 \mathrm{~b}$ & b * & 10,79 & b \\
\hline 74 & 9,23 & $b^{*}$ & 10,27 & a & 11,33 a & a* & 10,72 & b \\
\hline 75 & 9,79 & $a^{*}$ & 9,34 & $b^{*}$ & $10,56 \mathrm{a}$ & $\mathbf{a}$ & 10,24 & c \\
\hline 76 & 10,09 & $a^{*}$ & 10,33 & a & $10,51 \quad a$ & a & 10,65 & b \\
\hline 77 & 9,64 & $a^{*}$ & 10,76 & $\mathbf{a}$ & $10,54 \quad \mathrm{a}$ & $\mathbf{a}$ & 11,25 & $a^{*}$ \\
\hline 78 & 10,34 & a & 10,34 & a & $10,37 \quad b$ & b & 11,06 & $a^{*}$ \\
\hline 79 & 10,31 & a & 11,36 & $a^{*}$ & $9,83 \mathrm{~b}$ & b & 11,22 & $a^{*}$ \\
\hline 80 & 9,94 & $a^{*}$ & 9,60 & b & $10,62 \mathrm{a}$ & a & 10,56 & b \\
\hline 81 & - & & 10,49 & a & - & & 10,17 & c \\
\hline 82 & 8,98 & $\mathbf{b}^{*}$ & - & & $9,95 \mathrm{~b}$ & b & - & \\
\hline 83 & 9,91 & $\mathbf{a}^{*}$ & 9,27 & $b^{*}$ & 10,45 a & a & 10,42 & b \\
\hline 84 & 9,74 & $a^{*}$ & - & & $9,68 \mathrm{~b}$ & b & - & \\
\hline 85 & 9,66 & $a^{*}$ & 9,85 & b & $9,86 \mathrm{~b}$ & b & 10,67 & b \\
\hline 86 & 8,40 & $b^{*}$ & 9,21 & $b^{*}$ & 10,75 a & a & 10,75 & b \\
\hline 87 & 10,58 & a & 9,64 & b & $11,30 \mathrm{a}$ & a* & 9,53 & $\mathrm{~d}^{*}$ \\
\hline 88 & 10,39 & $\mathbf{a}$ & 9,45 & $b^{*}$ & $11,01 \quad a$ & a & 10,45 & b \\
\hline 89 & 10,03 & $a^{*}$ & 9,98 & a & 11,10 & a* & 10,68 & b \\
\hline 90 & 9,94 & $a^{*}$ & 9,77 & b & $10,03 \mathrm{~b}$ & b & 10,84 & b \\
\hline 91 & 9,87 & $a^{*}$ & 10,07 & a & $10,08 \mathrm{~b}$ & b & 9,64 & d \\
\hline 92 & 9,82 & $a^{*}$ & 9,92 & b & $10,38 \mathrm{~b}$ & b & 10,00 & c \\
\hline 93 & 9,96 & $a^{*}$ & 10,52 & a & $10,35 \mathrm{~b}$ & b & 10,14 & c \\
\hline 94 & 9,70 & $a^{*}$ & 9,87 & b & $9,68 \mathrm{~b}$ & b & 10,59 & b \\
\hline
\end{tabular}


Tabela A. Médias dos testcrosses para o caráter percentual de proteína (\%), dois testadores e dois locais. Piracicaba, 1999/2000.

\begin{tabular}{|c|c|c|c|c|c|c|c|}
\hline \multirow[t]{2}{*}{ Progênies } & \multicolumn{4}{|c|}{ Anhembi } & \multicolumn{3}{|c|}{ Caterpillar } \\
\hline & BR10 & & CML & 269 & BR108 & CML2 & \\
\hline 95 & 10,07 & $a^{*}$ & 9,84 & b & $10,23 \mathrm{~b}$ & $11,07 \mathrm{a}$ & $a *$ \\
\hline 96 & 10,75 & $\mathbf{a}$ & 11,22 & $a *$ & 10,66 a & $11,63 \mathrm{a}$ & $a *$ \\
\hline 97 & $9,90 a$ & $a *$ & 10,95 & $\mathbf{a}$ & $10,21 \mathrm{~b}$ & $11,08 \mathrm{a}$ & $a *$ \\
\hline 98 & 9,93 & $a^{*}$ & 9,33 & $b^{*}$ & $11,02 \mathrm{a} *$ & $11,70 \mathrm{a}$ & $a *$ \\
\hline 99 & - & & 9,62 & b & - & $11,05 \mathrm{a}$ & $a *$ \\
\hline 100 & $9,08 \mathrm{k}$ & $b^{*}$ & 10,28 & $\mathbf{a}$ & 10,57 a & 11,32 a & $a *$ \\
\hline 101 & 9,90 a & $a *$ & 9,30 & b* & 10,60 a & $10,54 \mathrm{~b}$ & \\
\hline 102 & $8,41 \quad b$ & $b^{*}$ & 10,92 & a & $9,93 \mathrm{~b}$ & $11,51 \mathrm{a}$ & $a *$ \\
\hline 103 & 10,56 & $\mathbf{a}$ & 10,41 & a & $10,38 \mathrm{~b}$ & $10,64 \mathrm{~b}$ & \\
\hline 104 & 10,45 & $\mathbf{a}$ & 10,94 & $\mathbf{a}$ & 10,67 a & $11,05 \mathrm{a}$ & a* \\
\hline 105 & $9,39 \mathrm{l}$ & $b^{*}$ & 9,73 & b & $10,35 \mathrm{~b}$ & $10,44 \mathrm{~b}$ & \\
\hline 106 & 10,53 & $\mathrm{a}$ & 10,00 & a & $11,02 \mathrm{a}^{*}$ & $10,28 \mathrm{c}$ & \\
\hline 107 & 10,02 & $a^{*}$ & 10,48 & $\mathbf{a}$ & $10,26 \mathrm{~b}$ & $10,64 \mathrm{~b}$ & b \\
\hline 108 & 9,72 & $a *$ & 8,99 & $b^{*}$ & 10,41 a & $9,55 \mathrm{~d}$ & $d^{*}$ \\
\hline 109 & 10,02 : & $a^{*}$ & 9,84 & b & $11,12 \mathrm{a} *$ & $9,66 \mathrm{~d}$ & d \\
\hline 110 & 9,261 & $b^{*}$ & 9,81 & b & $10,04 \mathrm{~b}$ & $9,72 d$ & d \\
\hline 111 & - & & 9,69 & b & - & $9,30 \mathrm{~d}$ & $d^{*}$ \\
\hline 112 & 9,591 & $b^{*}$ & 10,43 & a & $9,58 \quad b *$ & $10,01 \mathrm{c}$ & c \\
\hline 113 & $9,29 \mathrm{l}$ & $b^{*}$ & 9,93 & b & $10,30 \mathrm{~b}$ & $10,64 \mathrm{~b}$ & b \\
\hline 114 & 9,89 & $a^{*}$ & 10,25 & $\mathbf{a}$ & $10,31 \quad b$ & $10,87 \mathrm{~b}$ & b \\
\hline 115 & 10,73 & $\mathbf{a}$ & 9,36 & $b^{*}$ & 10,89 a & $8,96 \mathrm{~d}$ & $d *$ \\
\hline 116 & $9,48 \quad 1$ & $b^{*}$ & 10,30 & $\mathbf{a}$ & 10,57 a & $10,67 \mathrm{~b}$ & b \\
\hline 117 & $9,47 \quad 1$ & $b^{*}$ & 9,36 & b & $9,55 \mathrm{~b}$ & $10,10 \mathrm{c}$ & c \\
\hline 118 & - & & 10,59 & $\mathbf{a}$ & - & $10,45 \mathrm{~b}$ & b \\
\hline 119 & 10,18 & $a^{*}$ & 8,98 & $b^{*}$ & 9,99 b & $9,82 \mathrm{c}$ & c \\
\hline 120 & 9,86 & $a *$ & 8,94 & $b^{*}$ & 10,67 a & $9,23 \mathrm{~d}$ & $d^{*}$ \\
\hline
\end{tabular}

Médias seguidas da mesma letra não diferem significativamente pelo teste de Scott-Knott a 5\%

* difere significativamente da melhor testemunha pelo teste t a 5\% 
Tabela B. Médias dos testcrosses para o caráter percentual de óleo (\%), dois testadores e dois locais. Piracicaba, 1999/2000.

\begin{tabular}{|c|c|c|c|c|c|}
\hline \multirow[t]{2}{*}{ Progênies } & \multicolumn{2}{|c|}{ Anhembi } & \multicolumn{3}{|c|}{ Caterpillar } \\
\hline & BR108 & CML269 & BR108 & CML26 & \\
\hline 1 & $4,25 \mathrm{a}^{*}$ & $4,57 \mathrm{a}^{*}$ & $4,37 \mathrm{~b}^{*}$ & 4,82 & $a *$ \\
\hline 2 & $4,09 \quad b *$ & $4,83 \mathrm{a} *$ & $4,57 \mathrm{a} *$ & 4,93 & $a *$ \\
\hline 3 & $4,02 \quad b *$ & $4,55 \mathrm{a}^{*}$ & $4,27 \quad b *$ & 4,63 & $b^{*}$ \\
\hline 4 & $4,16 \quad b *$ & $4,42 \quad b *$ & $4,67 \mathrm{a} *$ & 5,11 & $a^{*}$ \\
\hline 5 & $4,22 \quad a^{*}$ & $4,49 \quad b *$ & $4,38 \quad b *$ & 4,52 & $b^{*}$ \\
\hline 6 & $4,15 \mathrm{~b} *$ & $4,59 \mathrm{a} *$ & $4,36 \quad b *$ & 4,73 & $a_{*}^{*}$ \\
\hline 7 & $4,22 \mathrm{a} *$ & $4,68 \mathrm{a} *$ & 4,47 a * & 4,76 & $a *$ \\
\hline 8 & $4,35 a^{*}$ & $4,43 b *$ & $4,43 \mathrm{a} *$ & 4,79 & a* \\
\hline 9 & $4,39 \mathrm{a}^{*}$ & $4,34 \quad b *$ & $4,53 \mathrm{a} *$ & 4,59 & b* \\
\hline 10 & $4,02 \quad b^{*}$ & $4,39 \quad b *$ & $4,46 a^{*}$ & 4,76 & $a *$ \\
\hline 11 & - & $4,62 \mathrm{a} *$ & - & 4,50 & b* \\
\hline 12 & 4,31 a * & - & $4,35 \quad b *$ & - & \\
\hline 13 & $4,46 a^{*}$ & $4,52 a^{*}$ & $4,55 \mathrm{a}^{*}$ & 4,76 & $a^{*}$ \\
\hline 14 & $4,15 \quad b *$ & $4,38 \mathrm{~b}$ & $4,52 \mathrm{a} *$ & 4,67 & a* \\
\hline 15 & $4,15 b *$ & $4,53 \mathrm{a} *$ & $4,27 \quad b *$ & 4,79 & $a^{*}$ \\
\hline 16 & $4,37 \quad a *$ & $4,44 \quad b *$ & 4,47 a* & 4,61 & b* \\
\hline 17 & $4,21 \quad a *$ & $4,62 \quad a^{*}$ & $4,54 \mathrm{a}^{*}$ & 4,91 & $a^{*}$ \\
\hline 18 & $3,96 \quad b *$ & $4,66 a *$ & $4,08 \mathrm{c}^{*}$ & 4,53 & $b^{*}$ \\
\hline 19 & $4,44 a *$ & $4,53 \mathrm{a}$ & $4,58 \mathrm{a} *$ & 4,75 & $a^{*}$ \\
\hline 20 & 4,24 a * & $4,49 \mathrm{~b} *$ & $4,34 \mathrm{~b} *$ & 4,71 & $a^{*}$ \\
\hline 21 & $4,28 a^{*}$ & $4,58 \mathrm{a}^{*}$ & $4,63 \mathrm{a} *$ & 4,52 & $\mathrm{~b}^{*}$ \\
\hline 22 & - & $4,32 \quad b *$ & - & 4,39 & $b^{*}$ \\
\hline 23 & $4,14 \quad b *$ & $4,45 \mathrm{~b} *$ & $4,44 a *$ & 4,71 & $a^{*}$ \\
\hline 24 & 4,42 a * & $4,64 \mathrm{a} *$ & $4,36 \quad b *$ & 4,77 & $a *$ \\
\hline 25 & $4,15 \quad b *$ & $4,37 b^{*}$ & $4,32 \quad b *$ & 4,55 & b* \\
\hline 26 & $4,13 \quad b *$ & $4,46 \quad b *$ & $4,32 \quad b *$ & 4,57 & b* \\
\hline 27 & 4,21 a* & $4,60 \mathrm{a} *$ & $4,56 \mathrm{a} *$ & 4,62 & b* \\
\hline 28 & $3,95 \quad b *$ & $4,49 \quad b *$ & $4,39 \quad b *$ & 4,69 & a* \\
\hline 29 & $4,24 \mathrm{a}^{*}$ & $4,43 \quad b *$ & 4,41 a* & 4,55 & $b^{*}$ \\
\hline 30 & $4,21 \quad a^{*}$ & 4,61 a * & 4,49 a * & 4,73 & $a^{*}$ \\
\hline 31 & $4,24 \mathrm{a} *$ & $4,66 \mathrm{a} *$ & 4,43 a* & 4,67 & a* \\
\hline 32 & $4,04 \quad b *$ & $4,69 \mathrm{a} *$ & $4,30 \quad b *$ & 4,58 & b* \\
\hline 33 & $4,11 \quad b *$ & $4,67 \mathrm{a} *$ & $4,59 \mathrm{a}^{*}$ & 4,75 & $a_{*}^{*}$ \\
\hline 34 & $4,21 \quad a *$ & $4,59 a^{*}$ & $4,35 \quad b *$ & 4,78 & $a *$ \\
\hline 35 & $4,10 \quad b *$ & $4,72 \quad a *$ & $4,20 \mathrm{c} *$ & 4,90 & $a^{*}$ \\
\hline 36 & $4,37 \quad a^{*}$ & $4,80 \mathrm{a} *$ & $4,58 \mathrm{a} *$ & 4,70 & a* \\
\hline 37 & $4,43 a^{*}$ & $4,47 \quad b *$ & $4,40 \quad b *$ & 4,80 & $a^{*}$ \\
\hline 38 & 4,38 a * & $4,39 \mathrm{~b} *$ & $4,47 \mathrm{a} *$ & 4,77 & $a^{*}$ \\
\hline 39 & $4,30 \mathrm{a} *$ & - & $4,62 \mathrm{a} *$ & - & \\
\hline 40 & $4,38 \mathrm{a}^{*}$ & $4,49 \quad b *$ & $4,44 a *$ & 4,79 & $a *$ \\
\hline 41 & $4,26 \mathrm{a} *$ & $4,27 \quad b *$ & $4,30 \quad b *$ & 4,43 & b* \\
\hline 42 & $4,26 \mathrm{a}^{*}$ & $4,36 \mathrm{~b} *$ & $4,10 \mathrm{c} *$ & 4,54 & b* \\
\hline 43 & $4,39 \quad a *$ & $4,52 a^{*}$ & $4,50 a^{*}$ & 4,60 & b* \\
\hline 44 & $4,26 \mathrm{a} *$ & $4,20 \mathrm{~b} *$ & $4,45 \mathrm{a} *$ & 4,66 & $a *$ \\
\hline 45 & $4,22 \quad a *$ & $4,61 \quad a *$ & $4,54 \mathrm{a}^{*}$ & 4,68 & $a_{*}^{*}$ \\
\hline 46 & 4,27 a * & $4,24 \mathrm{~b} *$ & $4,24 \mathrm{c}^{*}$ & 4,38 & $b^{*}$ \\
\hline 47 & 4,46 a * & $4,60 \mathrm{a} *$ & $4,61 \mathrm{a} *$ & 4,55 & b* \\
\hline
\end{tabular}


Tabela B. Médias dos testcrosses para o caráter percentual de óleo (\%), dois testadores e dois locais. Piracicaba, 1999/2000.

\begin{tabular}{|c|c|c|c|c|}
\hline \multirow[t]{2}{*}{ Progênies } & \multicolumn{2}{|c|}{ Anhembi } & \multicolumn{2}{|c|}{ Caterpillar } \\
\hline & BR108 & CML269 & BR108 & CML269 \\
\hline 48 & $4,16 b^{*}$ & - & $4,51 \mathrm{a}^{*}$ & - \\
\hline 49 & $4,39 \mathrm{a} *$ & $4,42 \quad b *$ & $4,54 \mathrm{a}^{*}$ & $4,83 \quad \mathrm{a} *$ \\
\hline 50 & $4,34 a^{*}$ & $4,46 \quad b *$ & $4,23 \mathrm{c}^{*}$ & $4,91 \mathrm{a}^{*}$ \\
\hline 51 & - & $4,40 \quad b *$ & - & $4,63 b *$ \\
\hline 52 & $4,14 \quad b *$ & $4,50 \quad b *$ & $4,23 \mathrm{c} *$ & $4,67 \mathrm{a} *$ \\
\hline 53 & $3,98 \quad b *$ & $4,46 \quad b *$ & $4,29 \quad b *$ & $4,83 \mathrm{a} *$ \\
\hline 54 & $4,05 \mathrm{~b} *$ & $4,53 \mathrm{a} *$ & $4,36 \quad b *$ & $4,72 a^{*}$ \\
\hline 55 & 4,28 a * & - & $4,59 \mathrm{a}^{*}$ & $=$ \\
\hline 56 & $4,13 \quad b *$ & $4,38 \quad b *$ & $4,48 \mathrm{a}^{*}$ & $4,91 \mathrm{a}^{*}$ \\
\hline 57 & $4,05 \mathrm{~b} *$ & $4,60 \mathrm{a} *$ & $4,38 \quad b *$ & $4,78 \mathrm{a} *$ \\
\hline 58 & $4,56 \quad a *$ & $4,69 \mathrm{a}^{*}$ & $4,49 \quad a^{*}$ & $5,05 \quad a *$ \\
\hline 59 & $4,15 b *$ & $4,48 \quad b *$ & $4,49 a *$ & $4,48 \quad b *$ \\
\hline 60 & 4,29 a * & $4,50 \quad b *$ & $4,46 a *$ & $4,68 \mathrm{a} *$ \\
\hline 61 & $4,18 \quad b *$ & - & $4,21 \mathrm{c}^{*}$ & - \\
\hline 62 & $3,77 \quad b *$ & $4,68 \mathrm{a}^{*}$ & $4,26 \quad b *$ & $4,68 \mathrm{a}^{*}$ \\
\hline 63 & $4,32 \quad a *$ & $4,59 \quad a *$ & $4,64 a *$ & $4,59 \quad b *$ \\
\hline 64 & $4,15 \quad b *$ & $4,60 a^{*}$ & $4,39 \quad b *$ & $4,67 a^{*}$ \\
\hline 65 & $4,21 \mathrm{a} *$ & $4,31 \quad b *$ & $4,19 \mathrm{c}^{*}$ & $4,44 \quad b *$ \\
\hline 66 & $4,28 \quad a *$ & $4,72 \quad a^{*}$ & $4,62 \quad a *$ & $4,68 a^{*}$ \\
\hline 67 & $4,38 a *$ & $4,45 \quad b *$ & $4,46 a *$ & $4,71 \mathrm{a} *$ \\
\hline 68 & $4,42 \quad a *$ & $4,56 \mathrm{a}^{*}$ & $4,56 \mathrm{a} *$ & $4,72 \quad \mathrm{a} *$ \\
\hline 69 & $4,28 \mathrm{a} *$ & $4,29 \quad b *$ & $4,52 \mathrm{a} *$ & $4,56 \quad b *$ \\
\hline 70 & $4,23 \quad \mathrm{a} *$ & $4,41 \quad b *$ & $4,17 c^{*}$ & $4,72 \quad a *$ \\
\hline 71 & $4,21 \quad a^{*}$ & $4,66 \quad a *$ & 4,47 a * & 4,70 a * \\
\hline 72 & $4,24 \quad a^{*}$ & $4,18 \quad b *$ & $4,25 \quad b *$ & 4,72 a * \\
\hline 73 & $4,41 \mathrm{a}^{*}$ & $4,50 \quad b *$ & $4,54 \mathrm{a} *$ & $4,59 \quad b *$ \\
\hline 74 & $4,13 \quad b *$ & $4,43 \quad b *$ & $4,21 \quad c^{*}$ & $4,71 \mathrm{a} *$ \\
\hline 75 & $4,15 \quad b *$ & $4,36 \quad b *$ & $4,36 \quad b *$ & $4,75 \mathrm{a} *$ \\
\hline 76 & $3,93 \quad b *$ & $4,43 \quad b *$ & $4,36 \quad b *$ & 4,65 b* \\
\hline 77 & $4,33 \mathrm{a} *$ & $4,36 \mathrm{~b} *$ & $4,71 \mathrm{a} *$ & $4,76 \mathrm{a} *$ \\
\hline 78 & $4,20 \quad b *$ & $4,46 \quad b *$ & $4,29 \quad b *$ & $4,62 \quad b *$ \\
\hline 79 & $4,20 \mathrm{~b} *$ & $4,66 a^{*}$ & $4,62 \mathrm{a}^{*}$ & $4,92 \mathrm{a} *$ \\
\hline 80 & $4,09 \quad b *$ & $4,42 b^{*}$ & $4,55 \mathrm{a}^{*}$ & $4,74 a *$ \\
\hline 81 & - & $4,86 \mathrm{a} *$ & - & $4,96 \mathrm{a} *$ \\
\hline 82 & $3,92 \quad b *$ & - & $3,93 \mathrm{c}^{*}$ & - \\
\hline 83 & $4,32 \quad a *$ & $4,60 a^{*}$ & $4,47 a *$ & $4,78 a^{*}$ \\
\hline 84 & $4,08 \quad b *$ & - & 4,43 a * & - \\
\hline 85 & $4,18 \quad b *$ & $4,45 b *$ & $4,39 \quad b *$ & $4,66 \mathrm{a} *$ \\
\hline 86 & $4,14 \quad b *$ & $4,42 \quad b *$ & $4,55 \mathrm{a} *$ & $4,54 \quad b *$ \\
\hline 87 & $4,32 \mathrm{a}^{*}$ & $4,66 \mathrm{a}^{*}$ & $4,28 \mathrm{~b} *$ & $4,70 \mathrm{a} *$ \\
\hline 88 & 4,43 a* & $4,50 \quad b *$ & 4,43 a * & $4,71 \mathrm{a} *$ \\
\hline 89 & $4,27 \mathrm{a}^{*}$ & $4,46 \mathrm{~b}^{*}$ & $4,48 \mathrm{a} *$ & $4,80 \mathrm{a} *$ \\
\hline 90 & $4,28 \mathrm{a}^{*}$ & $4,51 \quad b *$ & $4,28 \quad b *$ & $4,63 \quad b *$ \\
\hline 91 & $4,05 \quad b *$ & $4,36 \quad b *$ & $4,19 \mathrm{c}^{*}$ & $4,63 b *$ \\
\hline 92 & $4,06 \quad b *$ & $4,42 \quad b *$ & $4,04 \mathrm{c}^{*}$ & $4,48 \quad b *$ \\
\hline 93 & $4,01 \quad b *$ & $4,62 \mathrm{a} *$ & $4,24 \mathrm{c}^{*}$ & $4,73 \mathrm{a} *$ \\
\hline 94 & $4,29 \mathrm{a}^{*}$ & $4,52 \quad a *$ & $4,28 \quad b *$ & $4,85 \quad a *$ \\
\hline
\end{tabular}


Tabela B. Médias dos testcrosses para o caráter percentual de óleo (\%), dois testadores e dois locais. Piracicaba, 1999/2000.

\begin{tabular}{|c|c|c|c|c|c|}
\hline \multirow[t]{2}{*}{ Progênies } & \multicolumn{2}{|c|}{ Anhembi } & \multicolumn{3}{|c|}{ Caterpillar } \\
\hline & BR108 & CML269 & BR108 & CML26 & \\
\hline 95 & $4,35 a *$ & $4,43 b^{*}$ & 4,41 a * & 4,67 & $a *$ \\
\hline 96 & $4,16 \quad b *$ & $4,65 \mathrm{a}^{*}$ & $4,48 a^{*}$ & 4,75 & $a^{*}$ \\
\hline 97 & $4,32 \quad a *$ & $4,47 \quad b *$ & $4,44 a *$ & 4,71 & $a^{*}$ \\
\hline 98 & $4,43 \quad a *$ & $4,27 \quad b *$ & $4,55 a *$ & 4,80 & $a^{*}$ \\
\hline 99 & - & $4,42 \quad b *$ & - & 4,69 & $a *$ \\
\hline 100 & $4,15 \quad b *$ & $4,46 b *$ & $4,53 \mathrm{a} *$ & 4,77 & $a *$ \\
\hline 101 & $4,12 \quad b *$ & $4,43 \quad b *$ & $4,25 \quad b *$ & 4,78 & $a^{*}$ \\
\hline 102 & $3,83 \mathrm{~b} *$ & $4,47 \quad b *$ & $4,35 \quad b *$ & 4,57 & $b^{*}$ \\
\hline 103 & 4,49 a * & $4,58 \quad a *$ & $4,64 a^{*}$ & 4,82 & $a *$ \\
\hline 104 & $4,28 \mathrm{a} *$ & $4,62 \mathrm{a} *$ & $4,64 \mathrm{a} *$ & 4,76 & $a *$ \\
\hline 105 & $4,31 \mathrm{a} *$ & $4,52 a *$ & $4,51 \mathrm{a} *$ & 4,70 & $a *$ \\
\hline 106 & $4,44 a *$ & $4,44 \quad b *$ & $4,51 a^{*}$ & 4,60 & $b^{*}$ \\
\hline 107 & $4,27 \quad a *$ & $4,42 \quad b *$ & $4,50 a *$ & 4,59 & b * \\
\hline 108 & $4,32 \mathrm{a} *$ & $4,38 \quad b *$ & $4,35 \quad b *$ & 4,56 & $b^{*}$ \\
\hline 109 & $4,45 \mathrm{a} *$ & $4,29 b^{*}$ & $4,61 \mathrm{a} *$ & 4,62 & $b^{*}$ \\
\hline 110 & $3,99 \quad b *$ & $4,28 b^{*}$ & $4,17 c^{*}$ & 4,62 & $b^{*}$ \\
\hline 111 & - & $4,03 b^{*}$ & - & 4,28 & $b^{*}$ \\
\hline 112 & $4,30 \mathrm{a} *$ & $4,38 \quad b *$ & $4,38 \quad b *$ & 4,42 & $b^{*}$ \\
\hline 113 & $4,37 \mathrm{a} *$ & $4,37 b^{*}$ & $4,59 \mathrm{a} *$ & 4,71 & $a *$ \\
\hline 114 & $4,02 \quad b *$ & $4,07 \quad b *$ & $4,44 a^{*}$ & 4,64 & $b^{*}$ \\
\hline 115 & $4,27 \quad a *$ & $4,46 b^{*}$ & $4,36 \quad b *$ & 4,43 & b* \\
\hline 116 & $4,16 \quad b *$ & $4,42 \quad b *$ & $4,43 \quad a *$ & 4,59 & $b^{*}$ \\
\hline 117 & $4,02 \quad b *$ & $4,47 \quad b *$ & $4,10 c^{*}$ & 4,55 & $\mathrm{~b}^{*}$ \\
\hline 118 & - & $4,45 \quad b *$ & - & 4,57 & $b^{*}$ \\
\hline 119 & $4,36 \quad a *$ & $4,45 b *$ & $4,61 \quad a *$ & 4,67 & $a^{*}$ \\
\hline 120 & $4,23 \mathrm{a} *$ & $4,39 \quad b *$ & $4,42 \quad a^{*}$ & 4,43 & b* \\
\hline
\end{tabular}

Médias seguidas da mesma letra não diferem significativamente pelo teste de Scott-Knott a 5\%

* difere significativamente da melhor testemunha pelo teste t a $5 \%$ 
Tabela C. Médias testcrosses para o caráter peso de espigas ( $\mathrm{t} / \mathrm{ha})$, dois testadores e dois locais. Piracicaba, 1999/2000.

\begin{tabular}{|c|c|c|c|c|c|c|c|c|}
\hline \multirow[t]{2}{*}{ Progênies } & \multicolumn{4}{|c|}{ Anhembi } & \multicolumn{4}{|c|}{ Caterpillar } \\
\hline & \multicolumn{2}{|c|}{ BR108 } & \multicolumn{2}{|c|}{ CML269 } & \multicolumn{2}{|c|}{ BR108 } & \multicolumn{2}{|c|}{ CML269 } \\
\hline 1 & 2,74 & $a^{*}$ & 4,44 & $a^{*}$ & 5,841 & $b^{*}$ & 8,03 & $\mathbf{a}$ \\
\hline 2 & 3,91 & $a^{*}$ & 4,54 & $a^{*}$ & 7,17 & & 7,13 & $b^{*}$ \\
\hline 3 & 3,56 & $a^{*}$ & 4,58 & $a^{*}$ & 6,06 & b * & 9,63 & a \\
\hline 4 & 3,54 & $a^{*}$ & 4,21 & b* & 6,49 & $a^{*}$ & 7,70 & $b^{*}$ \\
\hline 5 & 3,90 & $a^{*}$ & 4,92 & $\mathbf{a}$ & 6,04 & b* & 6,48 & $b^{*}$ \\
\hline 6 & 4,37 & $\mathbf{a}$ & 3,22 & b* & 6,54 & a* & 7,16 & b* \\
\hline 7 & 2,76 & $a^{*}$ & 2,88 & $b^{*}$ & 6,31 & $a *$ & 7,10 & $b^{*}$ \\
\hline 8 & 3,79 & $a^{*}$ & 4,58 & $a^{*}$ & 5,95 & b * & 7,18 & $b^{*}$ \\
\hline 9 & 4,36 & a & 4,73 & $\mathbf{a}$ & 6,77 & $\mathbf{a}$ & 7,14 & $b^{*}$ \\
\hline 10 & 3,31 & $a^{*}$ & 4,70 & $\mathbf{a}$ & 6,20 & b* & 7,11 & b* \\
\hline 11 & - & & 3,77 & $b^{*}$ & - & & 6,46 & $b^{*}$ \\
\hline 12 & 3,34 & $a^{*}$ & - & & 6,12 & b* & - & \\
\hline 13 & 3,45 & a & 5,13 & a & 6,30 & $a *$ & 7,13 & $b^{*}$ \\
\hline 14 & 4,76 & $a^{*}$ & 3,54 & $b^{*}$ & 6,86 & $\mathbf{a}$ & 7,64 & $b^{*}$ \\
\hline 15 & 3,00 & a & 3,88 & $b^{*}$ & 5,93 & $b^{*}$ & 7,54 & $b^{*}$ \\
\hline 16 & 4,59 & $a^{*}$ & 4,44 & $a^{*}$ & 5,14 & b* & 7,37 & $b^{*}$ \\
\hline 17 & 3,43 & $a^{*}$ & 4,01 & $b^{*}$ & 6,88 & $\mathbf{a}$ & 6,91 & $b^{*}$ \\
\hline 18 & 3,44 & $a^{*}$ & 4,31 & $b^{*}$ & 6,33 & $a *$ & 7,28 & $b *$ \\
\hline 19 & 4,01 & $a^{*}$ & 4,36 & $b^{*}$ & 6,35 & a* & 9,16 & $\mathbf{a}$ \\
\hline 20 & 3,55 & a & 4,31 & $b^{*}$ & 5,14 & b* & 7,29 & $b^{*}$ \\
\hline 21 & 4,91 & $a^{*}$ & 4,42 & $a^{*}$ & 7,55 & $\mathbf{a}$ & 8,50 & a \\
\hline 22 & - & & 5,86 & $\mathbf{a}$ & - & & 7,82 & $a^{*}$ \\
\hline 23 & 3,90 & $a^{*}$ & 5,06 & $\mathbf{a}$ & 6,46 & $a^{*}$ & 7,56 & $b^{*}$ \\
\hline 24 & 3,79 & $a^{*}$ & 5,14 & a & 5,69 & $b^{*}$ & 8,16 & a \\
\hline 25 & 2,77 & $\mathbf{a}$ & 5,07 & a & 6,60 & a & 7,74 & $b^{*}$ \\
\hline 26 & 3,74 & $a^{*}$ & 4,61 & $a^{*}$ & 6,35 & $\mathrm{a} *$ & 7,03 & b* \\
\hline 27 & 5,24 & $a^{*}$ & 4,83 & a & 6,37 & $a^{*}$ & 7,36 & b* \\
\hline 28 & 3,44 & $a^{*}$ & 3,88 & $b^{*}$ & 6,15 & $b^{*}$ & 7,40 & $b^{*}$ \\
\hline 29 & 3,20 & $a^{*}$ & 5,15 & $\mathbf{a}$ & 5,82 & $b^{*}$ & 8,87 & $\mathbf{a}$ \\
\hline 30 & 3,84 & $a^{*}$ & 4,31 & $b^{*}$ & 7,57 & a & 7,89 & $a^{*}$ \\
\hline 31 & 3,21 & $a^{*}$ & 4,56 & $\mathbf{a}^{*}$ & 6,92 & $\mathbf{a}$ & 7,89 & $a^{*}$ \\
\hline 32 & 3,56 & $a^{*}$ & 4,89 & a & 5,49 & $b^{*}$ & 8,21 & a \\
\hline 33 & 3,13 & $a^{*}$ & 5,58 & $\mathbf{a}$ & 6,10 & b* & 7,25 & $b^{*}$ \\
\hline 34 & 3,21 & $a^{*}$ & 3,73 & $b^{*}$ & 6,83 & $\mathbf{a}$ & 7,64 & $b^{*}$ \\
\hline 35 & 3,63 & $a^{*}$ & 5,33 & a & 5,89 & $b^{*}$ & 7,79 & $b^{*}$ \\
\hline 36 & 2,71 & $a^{*}$ & 5,54 & a & 6,37 & $a^{*}$ & 6,84 & $b^{*}$ \\
\hline 37 & 4,05 & $a^{*}$ & 4,54 & $a^{*}$ & 6,96 & a & 7,41 & $b^{*}$ \\
\hline 38 & 3,74 & $a^{*}$ & 4,61 & $a^{*}$ & 7,14 & a & 7,76 & $b^{*}$ \\
\hline 39 & 2,88 & $a^{*}$ & - & & 6,57 & $a^{*}$ & - & \\
\hline 40 & 3,69 & $a^{*}$ & 4,08 & $b^{*}$ & 5,80 & $b^{*}$ & 6,28 & $b^{*}$ \\
\hline 41 & 3,61 & $a^{*}$ & 4,60 & $a^{*}$ & 5,86 & b* & 7,00 & $b^{*}$ \\
\hline 42 & 3,10 & $a^{*}$ & 4,02 & $b^{*}$ & 5,70 & $b^{*}$ & 7,89 & $a^{*}$ \\
\hline 43 & 3,16 & $a^{*}$ & 3,38 & $b^{*}$ & 5,00 & $b^{*}$ & 7,04 & $b^{*}$ \\
\hline 44 & 3,44 & $a^{*}$ & 4,52 & a & 7,18 & a & 8,07 & a \\
\hline 45 & 3,68 & $a^{*}$ & 3,92 & $b^{*}$ & 6,62 & $\mathbf{a}$ & 7,36 & $b^{*}$ \\
\hline 46 & 3,63 & $a^{*}$ & 3,66 & $b^{*}$ & 6,38 & $a^{*}$ & 6,51 & $b^{*}$ \\
\hline 47 & 4,88 & a & 4,41 & $a^{*}$ & 7,09 & $\mathbf{a}$ & 7,43 & $b^{*}$ \\
\hline
\end{tabular}


Tabela C. Médias testcrosses para o caráter peso de espigas ( $\mathrm{t} / \mathrm{ha}$ ), dois testadores e dois locais. Piracicaba, 1999/2000.

\begin{tabular}{|c|c|c|c|c|c|}
\hline \multirow[t]{2}{*}{ Progênies } & \multicolumn{3}{|c|}{ Anhembi } & \multicolumn{2}{|c|}{ Caterpillar } \\
\hline & BR1 & & CML269 & BR108 & CML269 \\
\hline 48 & 3,70 & $a *$ & - & $5,78 b^{*}$ & - \\
\hline 49 & 3,86 & $a^{*}$ & $3,90 \quad b *$ & $5,27 \quad b *$ & 8,10 a \\
\hline 50 & 2,94 & $a^{*}$ & $4,38 \quad b *$ & $5,96 \mathrm{~b} *$ & $7,79 \quad b *$ \\
\hline 51 & - & & $4,43 \mathrm{a} *$ & - & 8,30 a \\
\hline 52 & 4,55 & a & 4,75 a & $5,38 \quad b *$ & 8,65 a \\
\hline 53 & 3,67 & $a^{*}$ & $3,90 \quad b *$ & 6,65 a & 8,19 a \\
\hline 54 & 3,24 & $a *$ & $4,74 \quad a$ & $6,71 \quad a$ & $6,67 b *$ \\
\hline 55 & 4,15 & $\mathbf{a}$ & - & 7,35 a & - \\
\hline 56 & 2,94 & $a^{*}$ & $4,00 \quad b *$ & $6,60 \mathrm{a}$ & 8,29 a \\
\hline 57 & 3,27 & $a^{*}$ & $4,13 \quad b *$ & $5,86 \mathrm{~b} *$ & 9,72 a \\
\hline 58 & 3,14 & $a^{*}$ & $4,20 \quad b *$ & 5,46 b* & $7,61 \quad b *$ \\
\hline 59 & 4,11 & $a^{*}$ & $3,45 \quad b *$ & $5,70 \quad b *$ & $7,10 \quad b *$ \\
\hline 60 & 4,73 & a & $3,79 \quad b *$ & 7,58 a & $7,80 \quad b *$ \\
\hline 61 & 3,47 & $a^{*}$ & - & 6,82 a & - \\
\hline 62 & 2,64 & $a^{*}$ & $4,79 \mathrm{a}^{*}$ & $5,62 \mathrm{~b}^{*}$ & $7,39 \quad b *$ \\
\hline 63 & 3,69 & $a^{*}$ & $3,90 \quad b *$ & $6,20 \mathrm{~b} *$ & $7,09 \quad b *$ \\
\hline 64 & 3,62 & $a^{*}$ & $4,22 \quad b *$ & $7,28 \mathrm{a}$ & $6,86 \mathrm{~b} *$ \\
\hline 65 & 4,18 & a & $4,00 \quad b *$ & $4,95 \mathrm{~b} *$ & $7,44 \quad b *$ \\
\hline 66 & 3,49 & $a^{*}$ & $4,61 \quad a *$ & $6,64 \mathrm{a}$ & 8,20 a \\
\hline 67 & 3,48 & $a^{*}$ & $4,12 \quad b *$ & $6,60 \mathrm{a}$ & $7,73 \quad b *$ \\
\hline 68 & 3,83 & $a^{*}$ & $3,90 \quad b *$ & $6,34 a *$ & $7,27 \quad b *$ \\
\hline 69 & 3,21 & $a^{*}$ & $4,43 \quad a *$ & $5,50 \quad b *$ & $7,22 \quad b *$ \\
\hline 70 & 4,10 & $a^{*}$ & $3,87 \quad b *$ & $5,13 \mathrm{~b} *$ & 8,89 a \\
\hline 71 & 3,52 & $a^{*}$ & 4,68 a & $5,11 \quad b *$ & $7,60 \quad b *$ \\
\hline 72 & 3,35 & $a^{*}$ & $4,51 \quad a *$ & $5,71 \quad b *$ & $7,44 \quad b^{*}$ \\
\hline 73 & 3,45 & $a^{*}$ & $3,88 \quad b *$ & 7,35 a & $7,39 \quad b *$ \\
\hline 74 & 3,82 & $a^{*}$ & $4,29 \quad b *$ & $6,29 a^{*}$ & 8,37 a \\
\hline 75 & 3,73 & $a^{*}$ & $4,24 \quad b *$ & $5,15 b *$ & $7,49 \quad b *$ \\
\hline 76 & 2,95 & $a^{*}$ & $4,33 \quad b *$ & $7,71 \mathrm{a}$ & $7,19 \quad b *$ \\
\hline 77 & 3,52 & $a^{*}$ & $4,55 \mathrm{a} *$ & $6,56 \mathrm{a} *$ & $7,21 \quad b *$ \\
\hline 78 & 3,49 & $a^{*}$ & 4,73 a & $6,28 a^{*}$ & $7,03 \quad \mathrm{~b} *$ \\
\hline 79 & 3,17 & $a^{*}$ & $3,94 \quad b *$ & 6,83 a & 8,10 a \\
\hline 80 & 3,18 & $\mathbf{a} *$ & $3,50 \mathrm{~b} *$ & $6,31 \mathrm{a} *$ & $6,94 b^{*}$ \\
\hline 81 & - & & $3,98 \quad b *$ & - & $7,38 \quad b *$ \\
\hline 82 & 3,63 & $a^{*}$ & - & $5,39 \quad b *$ & - \\
\hline 83 & 3,47 & $a^{*}$ & $4,08 \quad b *$ & $6,01 \quad b *$ & $6,82 \quad b *$ \\
\hline 84 & 4,21 & $\mathbf{a}$ & - & $6,29 \mathrm{a} *$ & - \\
\hline 85 & 3,46 & $a^{*}$ & $4,90 \mathrm{a}$ & $6,53 \mathrm{a} *$ & 8,32 a \\
\hline 86 & 3,18 & $a^{*}$ & $3,77 \quad b *$ & 7,04 a & $7,28 \quad b *$ \\
\hline 87 & 4,31 & a & $3,48 \quad b *$ & $5,51 \quad b *$ & $7,74 \quad b *$ \\
\hline 88 & 4,51 & $\mathbf{a}$ & $4,64 \mathrm{a} *$ & $5,54 \quad b *$ & $7,66 b^{*}$ \\
\hline 89 & 3,15 & $a^{*}$ & 5,86 a & $5,45 \quad b *$ & $7,39 \quad b *$ \\
\hline 90 & 4,31 & $\mathbf{a}$ & 5,31 a & 7,07 a & 8,12 a \\
\hline 91 & 2,69 & $a^{*}$ & $4,27 \quad b *$ & $6,10 \quad b *$ & 7,60 b * \\
\hline 92 & 4,56 & a & $4,31 \quad b *$ & 7,25 a & $7,56 \quad b *$ \\
\hline 93 & 4,04 & $a *$ & $4,50 \mathrm{a}^{*}$ & $5,83 \quad b *$ & 7,92 a \\
\hline 94 & 3,57 & $a^{*}$ & 5,05 a & $6,04 \quad b *$ & 7,99 a \\
\hline
\end{tabular}


Tabela C. Médias testcrosses para o caráter peso de espigas ( $\mathrm{t} / \mathrm{ha})$, dois testadores e dois locais. Piracicaba, 1999/2000.

\begin{tabular}{|c|c|c|c|c|c|c|c|c|}
\hline \multirow[t]{2}{*}{ Progênies } & \multicolumn{4}{|c|}{ Anhembi } & \multicolumn{4}{|c|}{ Caterpillar } \\
\hline & BR10 & & CML2 & 269 & BR10 & & CMI & 269 \\
\hline 95 & 3,18 & $a *$ & 4,44 & $a *$ & $5,73 \mathrm{~b}$ & $b^{*}$ & 7,46 & \\
\hline 96 & 3,85 & $a^{*}$ & $3,41 \quad$ & $b^{*}$ & $5,78 \mathrm{~b}$ & & 6,94 & \\
\hline 97 & 3,59 : & $a^{*}$ & 5,20 & a & $5,50 \quad b$ & b* & 7,78 & b * \\
\hline 98 & 4,52 & a & $3,73 \mathrm{l}$ & b* & $5,34 \quad b$ & b* & 8,80 & \\
\hline 99 & . & & 5,75 & $\mathbf{a}$ & - & & 8,16 & \\
\hline 100 & 4,00 & $a^{*}$ & 4,77 & a & 8,21 a & & 7,94 & \\
\hline 101 & 3,26 & $a^{*}$ & $5,56 a$ & $\mathbf{a}$ & $6,85 \mathrm{a}$ & & 8,21 & \\
\hline 102 & 3,49 & $a^{*}$ & 4,57 a & $a^{*}$ & $5,92 \quad b$ & b* & 7,60 & b * \\
\hline 103 & 3,15 & $a^{*}$ & 4,34 & $b^{*}$ & $5,58 \quad b$ & b* & 7,77 & b* \\
\hline 104 & 3,48 & $a^{*}$ & 4,47 & $\mathrm{a} *$ & $6,21 \mathrm{~b}$ & b* & 8,27 & a \\
\hline 105 & 2,90 & $a^{*}$ & 5,21 & a & $6,53 \mathrm{a}$ & $a *$ & 8,05 & $\mathbf{a}$ \\
\hline 106 & 4,31 & a & 5,00 & a & $7,20 \quad a$ & a & 7,37 & b * \\
\hline 107 & 4,14 & $a^{*}$ & 4,13 & $b^{*}$ & $5,61 \quad b$ & b * & 8,10 & \\
\hline 108 & 3,77 & $a^{*}$ & 4,85 & $\mathbf{a}$ & $6,77 \mathrm{a}$ & & 8,47 & $\mathbf{a}$ \\
\hline 109 & 4,09 & $a^{*}$ & $3,97 \mathrm{k}$ & $b^{*}$ & $5,76 \mathrm{~b}$ & b* & 7,35 & b * \\
\hline 110 & 3,27 & $a^{*}$ & 4,51 & $a^{*}$ & $5,24 \mathrm{~b}$ & b * & 7,12 & b * \\
\hline 111 & - & & 3,85 & $b^{*}$ & - & & 7,31 & b* \\
\hline 112 & 5,29 & a & $4,01 \quad 1$ & $b^{*}$ & $6,60 \mathrm{a}$ & & 7,15 & b * \\
\hline 113 & 3,12 & $a^{*}$ & $3,95 \mathrm{k}$ & $b^{*}$ & $5,76 \mathrm{~b}$ & b * & 8,09 & $\mathbf{a}$ \\
\hline 114 & 2,68 & $a^{*}$ & 4,18 & $b^{*}$ & $5,82 \mathrm{~b}$ & b * & 7,10 & b * \\
\hline 115 & 3,96 & $a^{*}$ & 4,23 & $\mathbf{b}^{*}$ & $4,73 \mathrm{~b}$ & b * & 8,02 & \\
\hline 116 & 2,92 & $a^{*}$ & 3,37 & b * & $6,12 \mathrm{~b}$ & b * & 7,40 & b * \\
\hline 117 & 4,46 & a & 5,41 & a & $5,87 \mathrm{~b}$ & b* & 9,65 & $\mathbf{a}$ \\
\hline 118 & - & & 4,73 & a & - & & 8,06 & $\mathbf{a}$ \\
\hline 119 & 3,04 & $a^{*}$ & 3,90 & $\mathbf{b}^{*}$ & $6,97 \mathrm{a}$ & $\mathbf{a}$ & 7,70 & b * \\
\hline 120 & 3,19 & $a^{*}$ & 3,57 & $b^{*}$ & $5,73 \mathrm{~b}$ & b * & 7,97 & $\mathbf{a}$ \\
\hline
\end{tabular}

Médias seguidas da mesma letra não diferem significativamente pelo teste de Scott-Knott a 5\%

* difere significativamente da melhor testemunha pelo teste t a $5 \%$ 
Tabela D. Médias dos testcrosses para o caráter peso de grãos (t/ha), dois testadores e dois locais. Piracicaba, 1999/2000.

\begin{tabular}{|c|c|c|c|c|c|}
\hline \multirow[t]{2}{*}{ Progênies } & \multicolumn{3}{|c|}{ Anhembi } & \multicolumn{2}{|c|}{ Caterpillar } \\
\hline & BR1 & & CML269 & BR108 & CML269 \\
\hline 1 & 2,03 & $a^{*}$ & $3,28 b^{*}$ & $4,80 b^{*}$ & $6,15 b^{*}$ \\
\hline 2 & 2,98 & $a^{*}$ & $3,43 \quad b *$ & 5,73 a & 5,60 b * \\
\hline 3 & 2,77 & $a^{*}$ & $3,54 a^{*}$ & 5,01 b* & 7,52 a \\
\hline 4 & 2,71 & $a *$ & $3,31 \quad b *$ & 5,16 a * & $6,12 \quad b *$ \\
\hline 5 & 3,10 & $a *$ & 3,99 a & 5,09 a * & $5,26 \quad b *$ \\
\hline 6 & 3,48 & $a^{*}$ & $2,44 \quad b *$ & 5,50 a & $5,66 \quad b *$ \\
\hline 7 & 2,05 & $a^{*}$ & $2,23 \mathrm{~b} *$ & $4,99 \mathrm{~b} *$ & $5,73 \quad b *$ \\
\hline 8 & 2,84 & $a *$ & $3,62 \quad a *$ & $4,72 \quad b *$ & $5,86 \mathrm{~b} *$ \\
\hline 9 & 3,29 & $a *$ & $3,73 \quad a *$ & 5,18 a * & $5,87 \mathrm{~b} *$ \\
\hline 10 & 2,56 & $a *$ & $3,80 \mathrm{a} *$ & $5,06 \mathrm{a} *$ & 5,68 b * \\
\hline 11 & - & & $2,92 \quad b *$ & - & $5,09 \quad b *$ \\
\hline 12 & 2,57 & $a^{*}$ & - & $4,85 \mathrm{~b} *$ & - \\
\hline 13 & 2,65 & a * & 3,95 a & 5,11 a * & $5,61 \quad b *$ \\
\hline 14 & 3,78 & a & $2,56 \mathrm{~b} *$ & 5,69 a & $5,90 \quad b *$ \\
\hline 15 & 2,31 & $a^{*}$ & $2,99 \mathrm{~b} *$ & $4,84 \mathrm{~b} *$ & 5,99 b * \\
\hline 16 & 3,70 & a & 3,49 a * & $4,33 \mathrm{~b} *$ & $5,96 \quad b *$ \\
\hline 17 & 2,63 & $a *$ & $3,06 \mathrm{~b} *$ & 5,80 a & $5,57 \quad b *$ \\
\hline 18 & 2,70 & $a^{*}$ & $3,32 \quad b *$ & $5,28 \mathrm{a} *$ & $5,95 \mathrm{~b} *$ \\
\hline 19 & 3,17 & $a *$ & $3,44 \quad b *$ & $4,99 \quad b *$ & 7,43 a \\
\hline 20 & 2,86 & $a^{*}$ & $3,39 \quad b *$ & $4,11 \quad b *$ & $6,08 \quad b *$ \\
\hline 21 & 3,86 & $\mathbf{a}$ & $3,44 \quad b *$ & 6,09 a & 6,74 a \\
\hline 22 & - & & 4,83 a & - & 6,42 a * \\
\hline 23 & 3,07 & $a^{*}$ & 4,14 a & $5,16 a^{*}$ & 6,18 b * \\
\hline 24 & 3,01 & $a^{*}$ & 4,19 a & $4,65 \mathrm{~b} *$ & $6,16 \quad b *$ \\
\hline 25 & 2,06 & $\mathrm{a} *$ & $4,05 \mathrm{a}$ & 5,36 a * & 6,28 a* \\
\hline 26 & 2,91 & $a^{*}$ & $3,59 \mathrm{a} *$ & 5,21 a * & 5,70 b* \\
\hline 27 & 4,28 & $\mathbf{a}$ & $3,66 \mathrm{a} *$ & $5,08 \mathrm{a} *$ & $5,72 \quad b *$ \\
\hline 28 & 2,65 & $\mathrm{a} *$ & $2,87 \mathrm{~b} *$ & 5,06 a * & 5,45 b* \\
\hline 29 & 2,38 & $\mathrm{a} *$ & 3,99 a & $4,60 \mathrm{~b} *$ & 6,96 a \\
\hline 30 & 2,93 & $\mathrm{a} *$ & $3,25 \mathrm{~b} *$ & $6,13 \mathrm{a}$ & $6,15 \quad b *$ \\
\hline 31 & 2,49 & $a *$ & $3,40 \quad b *$ & 5,73 a & $6,19 \quad b *$ \\
\hline 32 & 2,72 & $a^{*}$ & $3,80 a *$ & $4,26 \quad b *$ & 6,51 a* \\
\hline 33 & 2,38 & $a *$ & $4,30 \mathrm{a}$ & 5,26 a * & $5,78 \quad b *$ \\
\hline 34 & 2,61 & $a *$ & $2,95 \mathrm{~b} *$ & 5,61 a & $5,84 \quad b *$ \\
\hline 35 & 2,73 & $a^{*}$ & $4,20 \mathrm{a}$ & $4,48 \quad b *$ & $6,20 \mathrm{~b} *$ \\
\hline 36 & 2,10 & $a *$ & 4,12 a & 5,17 a * & $5,90 \quad b *$ \\
\hline 37 & 3,21 & $\mathrm{a} *$ & $3,55 \mathrm{a} *$ & $5,58 \mathrm{a}$ & $5,69 \quad \mathrm{~b} *$ \\
\hline 38 & 2,93 & $\mathrm{a} *$ & $3,62 \quad a *$ & 5,87 a & $6,13 b *$ \\
\hline 39 & 2,13 & $a^{*}$ & - & $5,28 a^{*}$ & - \\
\hline 40 & 2,92 & $a^{*}$ & $3,20 \quad \mathrm{~b} *$ & 4,46 b * & $5,00 \quad b *$ \\
\hline 41 & 2,74 & $\mathrm{a} *$ & $3,68 \mathrm{a} *$ & $4,60 \quad b *$ & $5,84 \quad b *$ \\
\hline 42 & 2,30 & $\mathrm{a} *$ & $3,17 \quad b *$ & $4,59 \quad b *$ & $6,47 \quad a *$ \\
\hline 43 & 2,49 & $\mathrm{a} *$ & $2,70 \mathrm{~b} *$ & $3,83 \quad b *$ & $5,78 \quad b *$ \\
\hline 44 & 2,70 & a* & $3,66 \mathrm{a} *$ & 5,56 a & 6,65 a \\
\hline 45 & 2,90 & $\mathrm{a} *$ & $2,88 \mathrm{~b} *$ & 5,14 a * & $5,68 \quad b *$ \\
\hline 46 & 2,75 & $a *$ & $2,81 \quad b *$ & $5,30 a *$ & $5,11 \quad b *$ \\
\hline 47 & 3,98 & $\mathrm{a}$ & $3,39 \quad b *$ & 5,76 a & 5,73 b * \\
\hline
\end{tabular}


Tabela D. Médias dos testcrosses para o caráter peso de grãos (t/ha), dois testadores e dois locais. Piracicaba, 1999/2000.

\begin{tabular}{|c|c|c|c|c|}
\hline \multirow[t]{2}{*}{ Progênies } & \multicolumn{2}{|c|}{ Anhembi } & \multicolumn{2}{|c|}{ Caterpillar } \\
\hline & BR108 & CML269 & BR108 & CML26 \\
\hline 48 & $2,93 \mathrm{a}^{*}$ & - & $4,64 b^{*}$ & - \\
\hline 49 & $2,96 \mathrm{a} *$ & $3,15 \quad b *$ & $4,23 b *$ & $6,41 \quad a *$ \\
\hline 50 & $2,86 \mathrm{a}^{*}$ & $3,52 a^{*}$ & $4,75 \quad b *$ & 6,58 a \\
\hline 51 & - & $3,51 \mathrm{a}^{*}$ & - & 6,61 a \\
\hline 52 & 3,55 a & $3,79 a^{*}$ & $4,30 \quad b *$ & 6,94 a \\
\hline 53 & $2,96 \mathrm{a} *$ & $3,69 \mathrm{a}^{*}$ & 5,55 a & 6,69 a \\
\hline 54 & 2,44 a * & $3,71 \quad a *$ & 5,43 a & $5,40 \quad b *$ \\
\hline 55 & $3,26 \quad a *$ & - & $6,05 \mathrm{a}$ & - \\
\hline 56 & $2,31 \quad a *$ & $3,16 \quad b *$ & 5,48 a & $6,75 \mathrm{a}$ \\
\hline 57 & $2,62 \quad \mathrm{a} *$ & $3,18 \quad b *$ & $4,83 b *$ & 7,47 a \\
\hline 58 & $2,40 \quad a^{*}$ & $3,29 \mathrm{~b} *$ & $4,49 \mathrm{~b} *$ & $5,79 \quad b *$ \\
\hline 59 & $3,05 \mathrm{a} *$ & $2,70 \mathrm{~b} *$ & $4,58 \mathrm{~b} *$ & $5,73 \quad b *$ \\
\hline 60 & 3,71 a & $3,35 \mathrm{~b} *$ & $6,05 \mathrm{a}$ & $6,27 a^{*}$ \\
\hline 61 & $2,72 \mathrm{a}^{*}$ & - * & $5,60 \mathrm{a}$ & - \\
\hline 62 & $2,07 \mathrm{a} *$ & $3,72 a^{*}$ & $4,44 \mathrm{~b} *$ & $5,75 \quad b *$ \\
\hline 63 & $2,91 \mathrm{a} *$ & $2,85 \quad b *$ & $4,90 \quad b *$ & $5,64 \mathrm{~b} *$ \\
\hline 64 & $2,80 \mathrm{a} *$ & $3,31 \quad b *$ & 5,75 a & $6,06 \quad b *$ \\
\hline 65 & $3,28 \quad \mathrm{a} *$ & $3,21 \quad b *$ & $4,18 \quad b *$ & $6,12 \quad b *$ \\
\hline 66 & $2,71 \quad a^{*}$ & $3,58 a^{*}$ & $5,23 \mathrm{a}^{*}$ & $6,44 a *$ \\
\hline 67 & $2,80 \mathrm{a} *$ & $3,17 \quad b *$ & $5,38 \mathrm{a} *$ & $5,94 \mathrm{~b} *$ \\
\hline 68 & $3,07 \mathrm{a} *$ & $2,95 \mathrm{~b} *$ & $5,15 \mathrm{a}^{*}$ & $5,74 \quad b *$ \\
\hline 69 & $2,52 a *$ & $3,64 a^{*}$ & $4,41 \quad b *$ & $5,71 \quad b *$ \\
\hline 70 & 3,19 a * & $3,01 \quad b *$ & $3,99 \quad b *$ & 7,24 a \\
\hline 71 & $2,80 \mathrm{a} *$ & $3,68 \mathrm{a} *$ & $4,09 \quad b *$ & $5,90 \mathrm{~b} *$ \\
\hline 72 & $2,62 \mathrm{a} *$ & $3,45 b *$ & $4,63 \quad b *$ & $5,91 \quad \mathrm{~b} *$ \\
\hline 73 & $2,74 a^{*}$ & $2,98 \mathrm{~b} *$ & $6,07 \mathrm{a}$ & $5,72 \quad b *$ \\
\hline 74 & $3,09 \quad a^{*}$ & $3,18 \quad b *$ & $5,19 \mathrm{a} *$ & $6,34 \mathrm{a} *$ \\
\hline 75 & 2,89 a * & $3,32 \quad b *$ & $4,28 \mathrm{~b} *$ & $6,00 \quad b *$ \\
\hline 76 & 2,41 a * & $3,42 \quad b *$ & $6,34 \mathrm{a}$ & $5,78 \quad b *$ \\
\hline 77 & $2,74 \mathrm{a} *$ & $3,55 \mathrm{a}^{*}$ & $5,25 \mathrm{a}^{*}$ & $5,95 \quad b *$ \\
\hline 78 & $2,40 \quad a^{*}$ & $3,77 a^{*}$ & $4,96 \quad b *$ & $5,42 \quad b *$ \\
\hline 79 & 2,42 a * & $3,15 \quad b *$ & 5,58 a & $6,35 \mathrm{a} *$ \\
\hline 80 & $2,44 a *$ & $2,63 \mathrm{~b} *$ & $5,05 \mathrm{a} *$ & $5,38 \quad b *$ \\
\hline 81 & - & $2,99 \quad b *$ & - & $5,95 \mathrm{~b} *$ \\
\hline 82 & $2,86 \mathrm{a}^{*}$ & - & $4,31 \quad b *$ & - \\
\hline 83 & $2,73 a^{*}$ & $3,20 \quad b *$ & 4,80 b* & $5,42 \quad b *$ \\
\hline 84 & 3,24 a * & - & $5,07 \mathrm{a}^{*}$ & - \\
\hline 85 & $2,73 \mathrm{a} *$ & $3,94 \mathrm{a} *$ & $5,40 \mathrm{a} *$ & $6,58 \mathrm{a}$ \\
\hline 86 & 2,44 a * & $2,93 \mathrm{~b} *$ & 5,81 a & $5,69 \quad b *$ \\
\hline 87 & $3,37 \quad a^{*}$ & $2,65 \mathrm{~b} *$ & $4,47 \quad b *$ & $6,27 a^{*}$ \\
\hline 88 & 3,99 a & 3,61 a * & $4,46 \quad b *$ & $6,16 \quad b *$ \\
\hline 89 & $2,32 \quad \mathbf{a} *$ & $4,72 \quad a$ & $4,30 \quad b *$ & $5,77 \quad b *$ \\
\hline 90 & $3,42 \quad a^{*}$ & 4,17 a & $5,90 \mathrm{a}$ & $6,49 a^{*}$ \\
\hline 91 & $2,06 \mathrm{a} *$ & $3,32 \quad b *$ & $4,84 \mathrm{~b} *$ & $6,01 \quad b *$ \\
\hline 92 & 3,40 a * & $3,30 \quad b *$ & 5,92 a & $5,81 \quad b *$ \\
\hline 93 & 3,18 a * & $3,39 \quad b *$ & $4,64 \quad b *$ & $6,48 \mathrm{a}^{*}$ \\
\hline 94 & 2,81 a * & $4,07 \quad \mathrm{a}$ & $4,70 \quad b *$ & $6,21 \quad b *$ \\
\hline
\end{tabular}


Tabela D. Médias dos testcrosses para o caráter peso de grãos ( $\mathrm{t} / \mathrm{ha})$, dois testadores e dois locais. Piracicaba, 1999/2000.

\begin{tabular}{|c|c|c|c|c|c|c|c|}
\hline \multirow[t]{2}{*}{ Progênies } & \multicolumn{4}{|c|}{ Anhembi } & \multicolumn{3}{|c|}{ Caterpillar } \\
\hline & BR1 & & CML & 269 & BR108 & CML & 269 \\
\hline 95 & 2,38 & a* & 3,43 & $\mathrm{~b}^{*}$ & $4,47 b^{*}$ & 5,70 & $\mathrm{~b}^{*}$ \\
\hline 96 & 3,07 & a * & 2,49 & $b^{*}$ & $4,74 \mathrm{~b} *$ & 4,92 & $b^{*}$ \\
\hline 97 & 2,80 & $a *$ & 4,07 & & $4,50 \quad b *$ & 6,09 & b* \\
\hline 98 & 3,60 & $\mathbf{a}$ & 2,80 & b* & $4,27 \mathrm{~b} *$ & 6,67 & \\
\hline 99 & - & & 4,32 & $\mathbf{a}$ & - & 6,43 & $\mathrm{a}^{*}$ \\
\hline 100 & 3,13 & $a^{*}$ & 3,76 & $a^{*}$ & $6,70 \mathrm{a}$ & $6,03 \mathrm{l}$ & $b^{*}$ \\
\hline 101 & 2,52 & $a *$ & 4,44 & a & $5,54 \mathrm{a}$ & 6,48 & a* \\
\hline 102 & 2,67 & a * & 3,48 & $a *$ & $4,74 \quad b *$ & 5,99 & b* \\
\hline 103 & 2,40 & a * & 3,28 & b* & $4,35 \mathrm{~b} *$ & 6,06 & b* \\
\hline 104 & 2,62 & $a^{*}$ & 3,53 & $a^{*}$ & $4,96 \mathrm{~b} *$ & 6,64 & \\
\hline 105 & 2,24 & $a^{*}$ & 4,18 & $\mathbf{a}$ & $5,28 a^{*}$ & 6,08 & $\mathrm{~b} *$ \\
\hline 106 & 3,63 & $\mathbf{a}$ & 3,89 & $a^{*}$ & 5,63 a & 5,78 & b* \\
\hline 107 & 3,23 & a * & 3,16 & $b^{*}$ & $4,42 \quad b *$ & 6,11 & b* \\
\hline 108 & 2,89 & $a^{*}$ & 3,79 & $a^{*}$ & $5,50 \mathrm{a}$ & 6,43 & $a^{*}$ \\
\hline 109 & 3,24 & $a^{*}$ & 3,09 & b* & $4,71 \mathrm{~b} *$ & 5,89 & b* \\
\hline 110 & 2,61 & $a^{*}$ & 3,68 & $a *$ & $4,36 \quad b *$ & 5,66 & b* \\
\hline 111 & - & & 3,02 & b* & - & 5,73 & b* \\
\hline 112 & 4,30 & $\mathbf{a}$ & 3,15 & $b^{*}$ & $5,29 \mathrm{a} *$ & 5,62 & $b^{*}$ \\
\hline 113 & 2,45 & $a^{*}$ & 3,05 & $b^{*}$ & $4,87 \mathrm{~b} *$ & 6,23 & $a^{*}$ \\
\hline 114 & 2,07 & $a^{*}$ & 3,27 & b* & $4,79 \mathrm{~b} *$ & 5,78 & b* \\
\hline 115 & 3,20 & $a *$ & 3,36 & $b^{*}$ & $3,82 \quad b *$ & $6,39 a$ & $a_{*}^{*}$ \\
\hline 116 & 2,26 & $\mathrm{a} *$ & 2,48 & b* & $5,05 \mathrm{a} *$ & 5,49 & b* \\
\hline 117 & 3,68 & a & 4,25 & a & $4,80 \mathrm{~b} *$ & 7,43 : & a \\
\hline 118 & & $\mathrm{a} *$ & 3,60 & $\mathrm{a} *$ & $-\quad *$ & 6,32 & $\mathrm{a} *$ \\
\hline 119 & 2,35 & $a *$ & 3,08 & b * & $5,80 \mathrm{a}$ & $6,26:$ & \\
\hline 120 & 2,50 & $\mathrm{a} *$ & 2,71 & b* & $4,54 \quad b *$ & $6,17 \mathrm{l}$ & b* \\
\hline
\end{tabular}

Médias seguidas da mesma letra não diferem significativamente pelo teste de Scott-Knott a 5\%

* difere significativamente da melhor testemunha pelo teste $\mathrm{t}$ a $5 \%$ 